دور جمعيات الاصلاح الزراعى فى تسويق القطن فى محافظة البحيرة

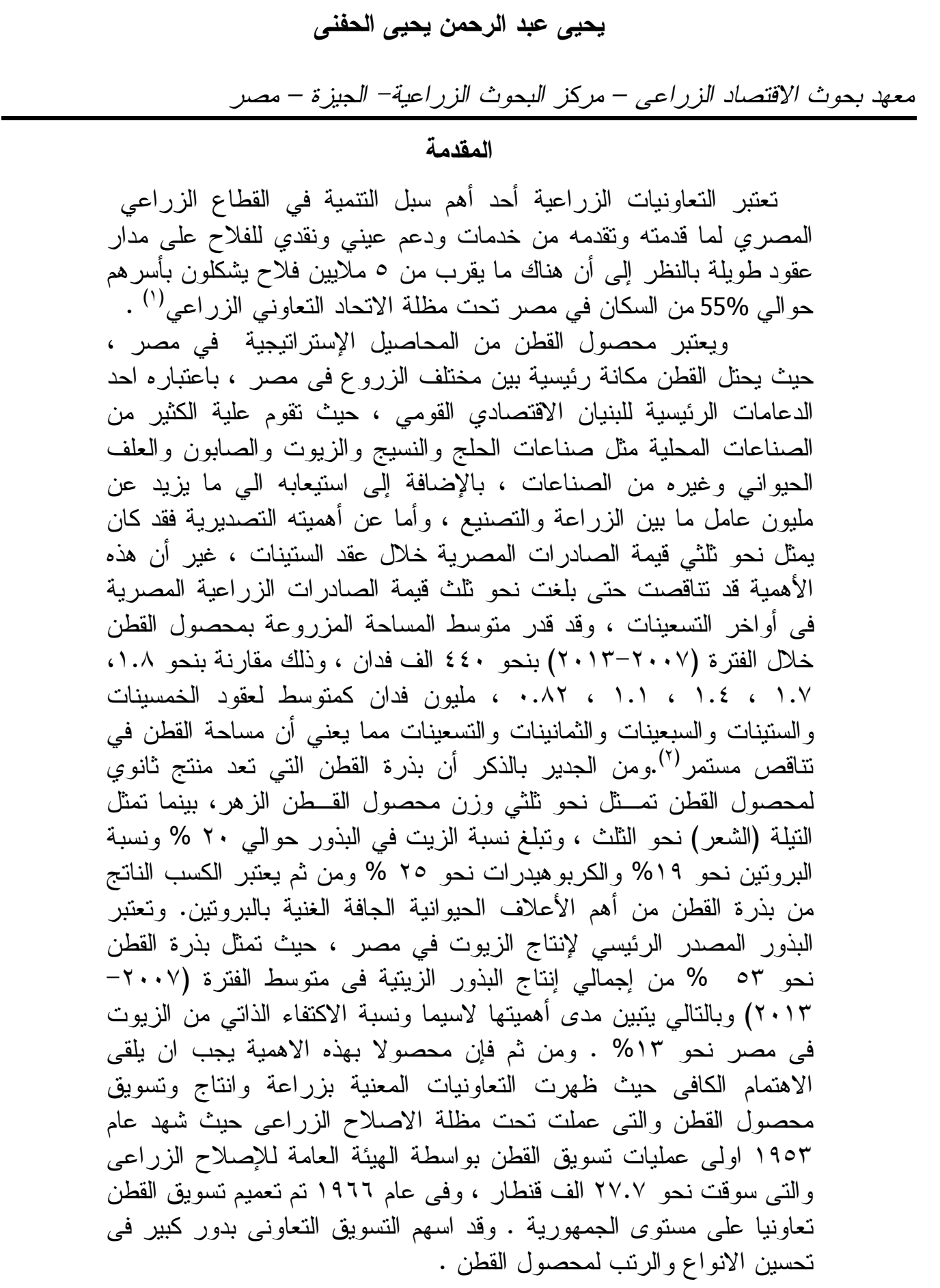

( (1) فوزى عبد العزيز الثناذلى (دكتور ) و آخرون ، در اسة ميدانية حول إعادة هيكلة التعاونيات الزر اعية لتفعيل دورها فى التتمية

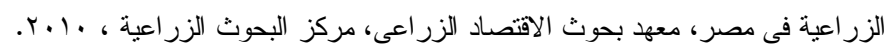

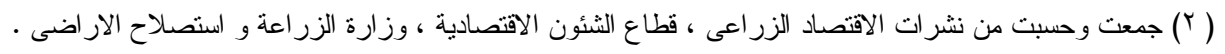




\section{مشكلة البحث}

يعد تسويق القطن فى مصر وما يحيط به من مشاكل وعثر ات من الاهمية بمكان وخاصـــة

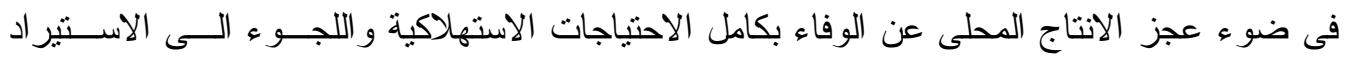

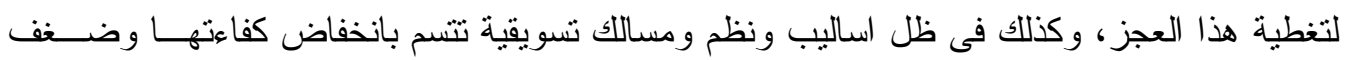

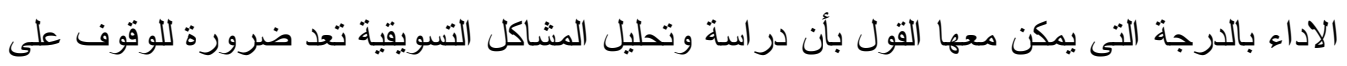

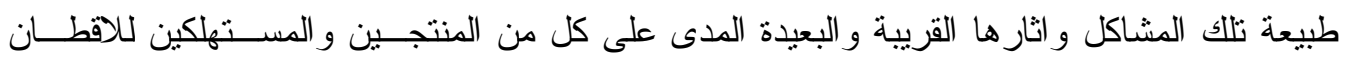

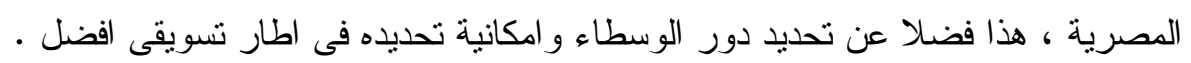
فعلى الرغم من أهمية الدور المحوري لجمعيات الإصلاح الزراعى فئى في تحسين الحالة الاقتصادية والاجتماعيه لكافة المزارعين على مستوى الجمهورية وخاصة بعد نطبيق سياسات

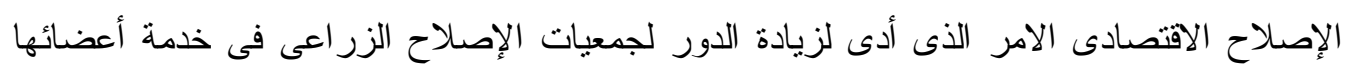
بنوفير مستلزمات الانتاج وقيامها بنسويق المحاصيل خاصة المحاصيل النى لها ميزه نسبيل الاديه كالقطن

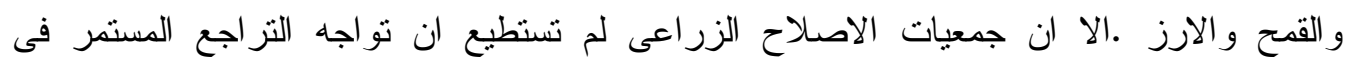

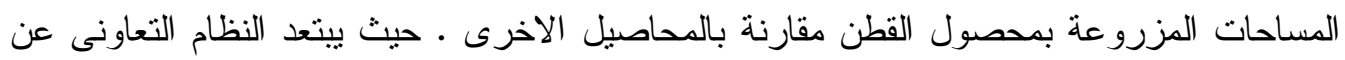

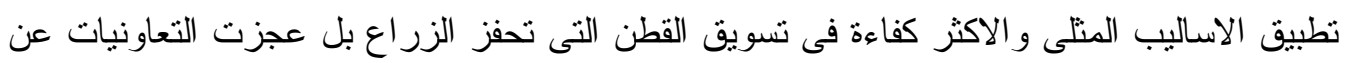
تحرير تجارة القطن بما يحقق صالح الزراع ، بل واجهت تعاونيات القطن العديد من المشكلات

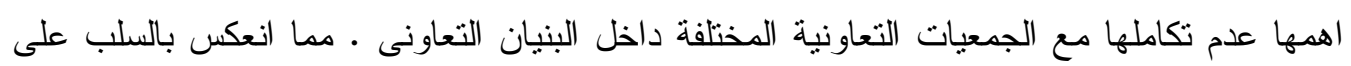

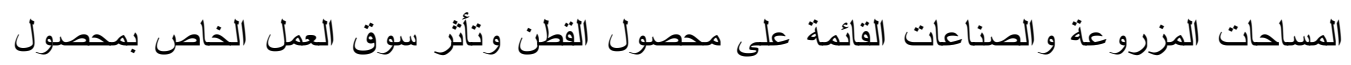
القطن و الذى يعمل فيه نحو مليون عامل (') .

\section{هدف البحث}

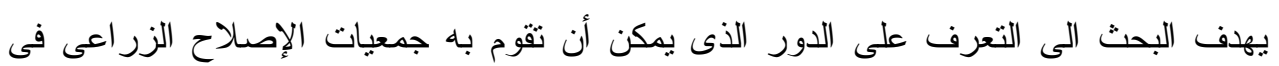

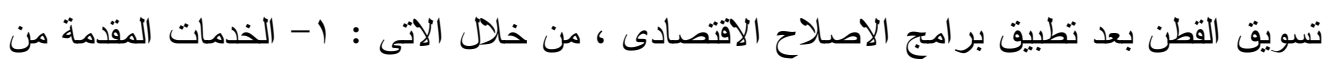

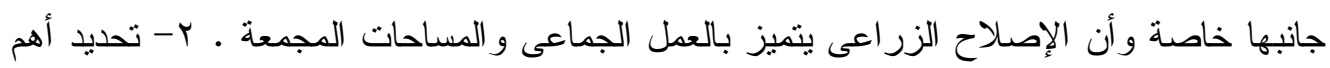

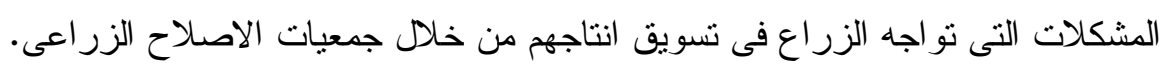

\section{الطريقة البحثية}

اعتمدت الدراسة على الأسلوب التحليلي من الناحيتين الوصفية و الكمية حيث ثم الاستعانة ببعض الته الاساليب الاحصائية مثل المنوسط الحسابى و المتوسط الهندسى لحساب متوسطات النسب ، و و الاتجاه

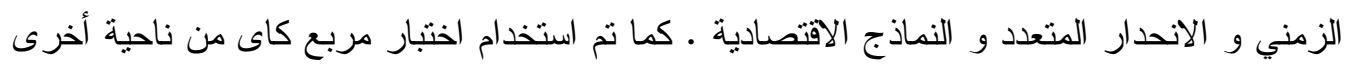
فى تحليل آراء المز ارعين التى جمعت من خلال استمارة الاسنبيان و التى صممت خصيصا لهذه

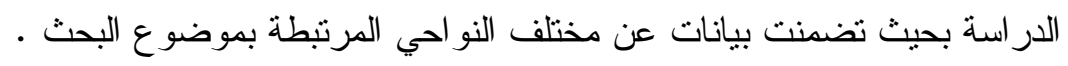




\section{مصادر البيانات}

اعتمد البحث على مصدرين أساسيين للبيانات هما : البيانات الثانوية وتشمل:- الجهات الحكومية و غير الحكومية ، المنشورة منها وغير المنشورة حيث استمدت البيانات الثانوية الاساسية من بيانات الهيئة العامة للاصلاح الزر اعى بوزارة الزراعة ، كائه كما تم الاستعانة بالابحاث المرتبطة

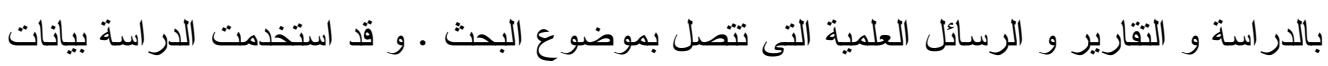

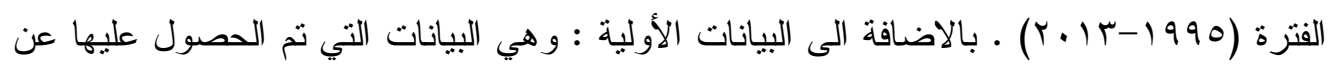
طريق استمارة الاستبيان الخاصة بدور جمعيات الاصلاح الزراعى فى تسويق القطن بمحافظة

\section{السياسة القطنية المصرية}

البحيرة.

شهد قطاع القطن المصرى العديد من التطورات والتدخلات الحكومية خلال نصف القرن

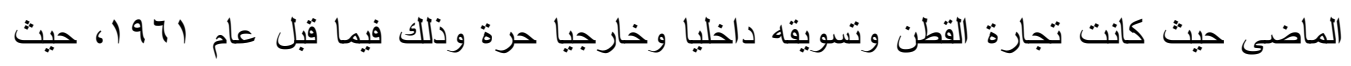

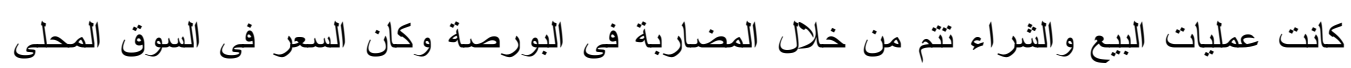

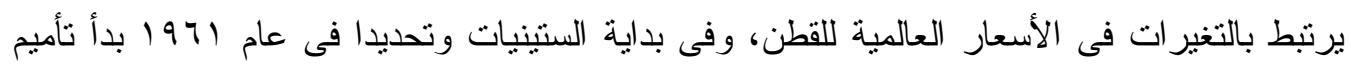

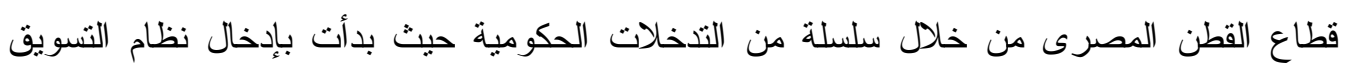
التعاونى للقطن و الذى تزامن معه نظام التوريد الاجبارى للقطن فضلا عن ذلك التحكم فى الرقعة المزروعة قطنا من خلال نظام الدورة الزراعية، وعن طريق ذللك أمكن للحكومة احكام السبطرة

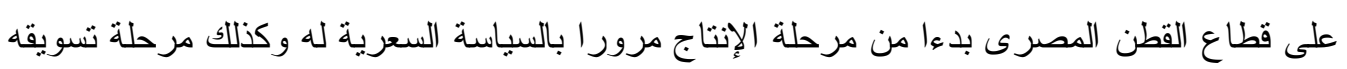

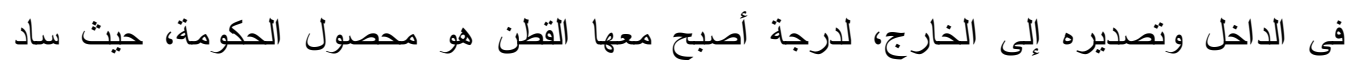

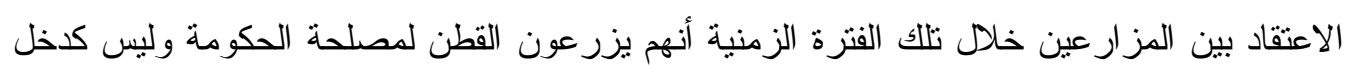

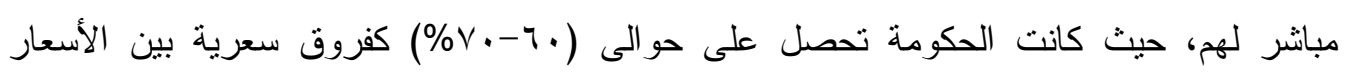
المحلية و السعر السائد فى الأسواق العالمية للقطن من خلا إحتكار الحكومة لعملية تسويق وتجارة

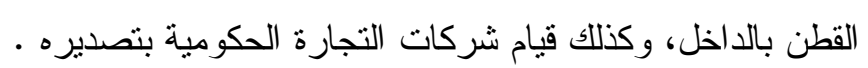

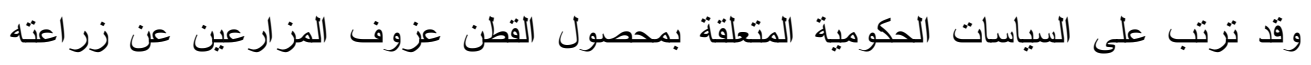

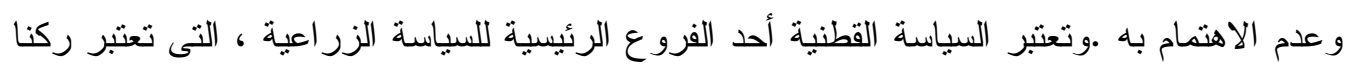

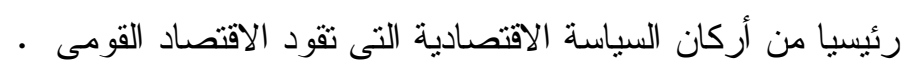

\section{تعريف السياسة القطنية}

السياسة القطنية هى مجموعة الإجر اءات التى تتخذها الدولة و المتعلقة بشئون القطن لتحقق بها

الأهداف الرئيسية المرجوة لصالح الاقتصاد القومى خلال فترة زمنية معينة.

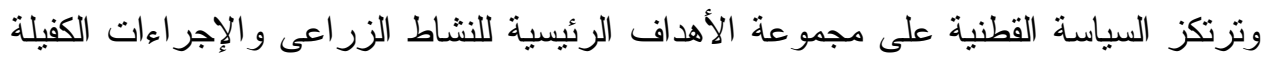
بتحقيق هذه الأهداف ، ويمكن تقسيم أهداف السياسات القطنية إلى هدفين رئيسين هما :

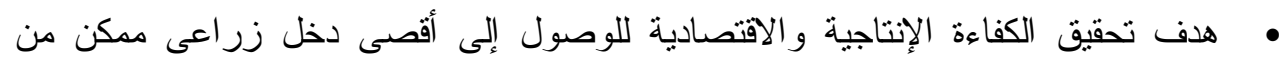

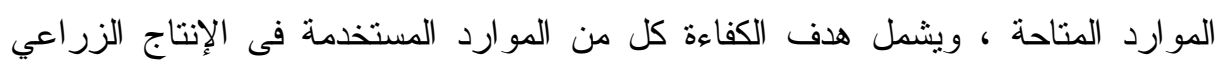


و التسويق الزراعى ، كما يشمل أيضا زيادة الحصيلة من الصادرات الزراعية القطنية وكذللك النهوض بالصناعات القطنية و النسجية. • هدف عداله توزيع الدخل فى القطاع القطنى فيما بين القطاع الزراعى والقطاع غير الزر اعى ،و ذلك وفقا لما يقرره المجتمع لمكونات العدالة التوزيعية بين جميع المز ارعين.

\section{الأهمية النسبية لأصناف القطن المصرية}

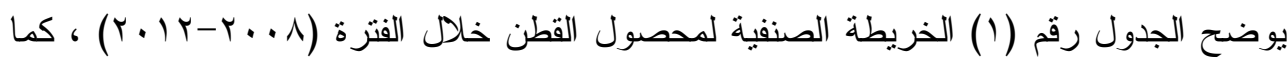
يتبين من الجدول رقم (Y) الاهمية النسبية لاهم اصناف القطن المزروعة فى جمهورية مصر العربية

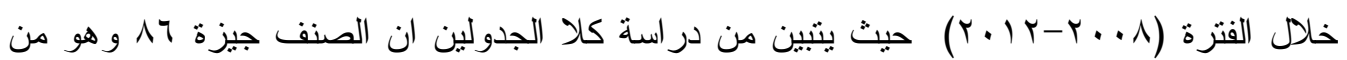

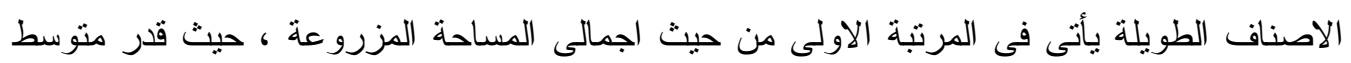

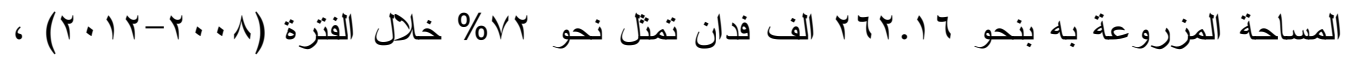

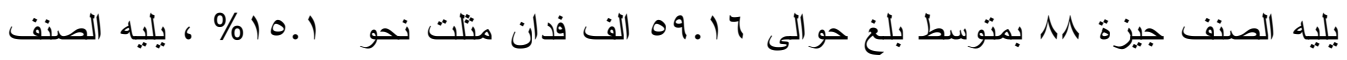

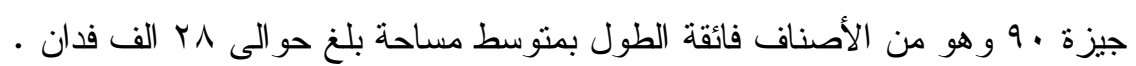

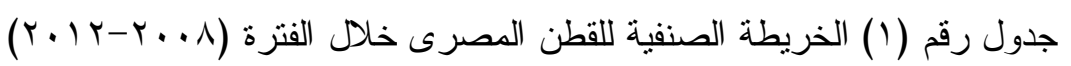
المساحة :فدان

\begin{tabular}{|c|c|c|c|c|c|c|c|c|c|c|c|c|}
\hline \multicolumn{12}{|c|}{ الأصناف } & \multirow[b]{2}{*}{ السنوات } \\
\hline الاجمالى & أخرى & جيزة & جيزة & جيزة & جيزة & جيزة & جيزة & جيزة & $\begin{array}{l}\text { جيزة } \\
\text { A. }\end{array}$ & $\begin{array}{l}\text { جيزة } \\
\text { v. }\end{array}$ & جيزة & \\
\hline riry.A & rTM & - & rrV & rv & $\Delta Q \Lambda T Y$ & 110 & r.orml & $\Psi \xi$ & $r r \leqslant 0$ & rq & rA & $r \cdots \wedge$ \\
\hline TME\&T\& & M & $1 \xi \xi$ & rAqAT & - & r\&q1q & . & r.olr. & - & $1 \sum A \cdot r$ & $\mathrm{~m}$ & - & $r . .9$ \\
\hline r|q|\&1 & $1 \xi$ & 0.1 & $r \xi . q r$ & - & VIV.r & $\$$ & rarrso & - & a71r & AAT & - & r.1. \\
\hline or.irr & 7. & $\| r \mid$ & ro.1r & - & १А८.. & rv & rvirag & - & IrmAs & - & - & $r .11$ \\
\hline rerrq. & irr & rav & rA191 & - & r.011 & $\varepsilon v$ & rMTh.A & - & 7170 & - & $\wedge$ & r.lr \\
\hline riraor & 117 & rit & $r A \cdots\rceil$ & 0 & 0917. & $\{\wedge$ & rititr & 0 & IrTys & roo & v & المنوسط \\
\hline
\end{tabular}

المصدر : قطاع الثئون الاقتصادية ، الادارة المركزية للاقتصاد الزر اعى ،نشرة الاقتصاد الزر اعى ، اعداد مختلفة .

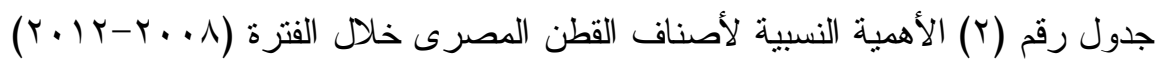

المساحة :فدان

\begin{tabular}{|c|c|c|c|c|c|c|c|c|c|}
\hline \multicolumn{4}{|c|}{ الاهمية النسبية } & \multirow{2}{*}{ الاجمالى } & \multirow{2}{*}{ جيزة .9 } & \multirow{2}{*}{ جيزة MN } & \multirow{2}{*}{ جيزة 11} & \multirow{2}{*}{ جيزة . A } & \multirow{2}{*}{ السنو ات } \\
\hline جيزة .9 & جيزة MN & جيزة 1 & جيزة . A & & & & & & \\
\hline$\wedge$ & 19 & 77 & $r$ & riry+A & rTYsqa & 09174 & r.orTI & $r+\varepsilon=0$ & $r \cdots 1$ \\
\hline 1. & ir & vr & 0 & rAsETE & rAqAT & P\$q/q & r.olr. & $\mid \xi \Lambda \cdot Y$ & $r \ldots q$ \\
\hline v & 19 & $n$ & $r$ & M१व|\&1 & $r \xi .9 r$ & VIV.r & marrso & & r.1. \\
\hline v & 19 & $n$ & $r$ & Or.irr & ro.1r & QАA... & ryitaq & IrTAA & $r .11$ \\
\hline$\wedge$ & 9 & $\wedge$. & $r$ & rerry. & ralal & r.011 & $r m 4 \lambda \cdot A$ & 71470 & r.lr \\
\hline v.va & $10.1 \%$ & $v 1 . q$. & r.or & raraor & $r A \cdots+$ & 0917. & Firiq & IrqvE & المتوسط \\
\hline
\end{tabular}

المصدر : قطاع الثئئن الاقتصادية ، الادارة المركزية للاقتصاد الزر اعى ،نشرة الاقتصاد الزر اعى ، اعداد مختلفة . 
Extra long staple cotton الأقطان فائقة الطول

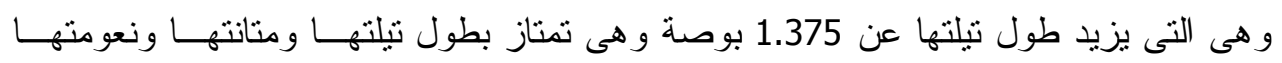

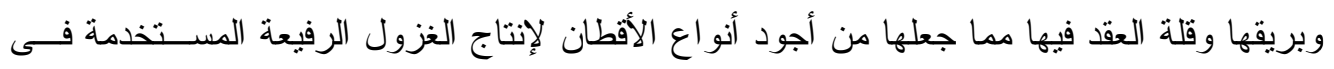

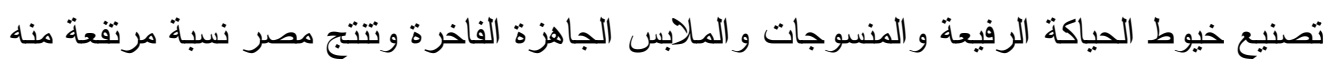

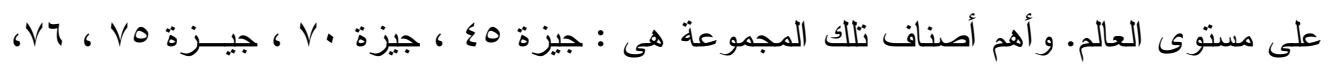

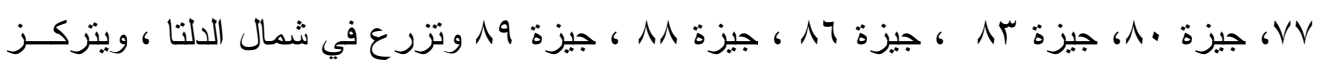
إنتاج تلك الأصناف في محافظات الوجه البحري (البحيرة، وكفر الثيخ).

التسويق المحلي للقطن المصري

تعد الاسواق و المؤسسات و الهيئات و النظم النسويقية فى الدول النامية بصفة خاصة من المحددات الرئيسية للتتمية الاقتصادية والاجتماعية ، وتتسم هذة المنظومة التسويقية عامة و الزر اعية

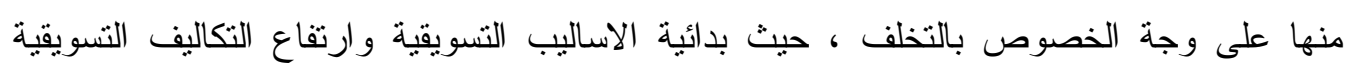
وعدم التو افق بين هذة التكاليف من جهة و الوظائف النسويقية من جهة اخرى ويبدا نسويق المنتجات

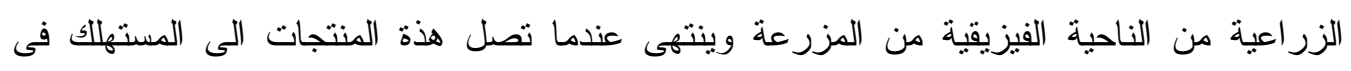
الثكل و المكان المناسبين والوقت الملائم ورغبات ذلك المستهلك ومن ثم فإن من الطبيعى أن تتعدد

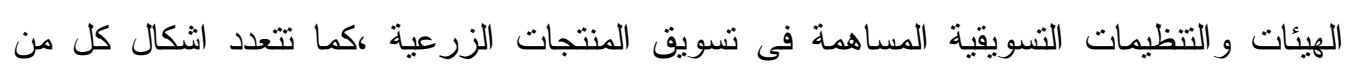
الوسطاء والخدمات و الوظائف التسويقية ابتداء من المنتج وحتى المستهلك النهائى ويتم تبادل المنتجات الزر اعية تلاك خلال عدة انواع من الاسواق لعل من اثشهرها الاسواق المحلية و التجميعية

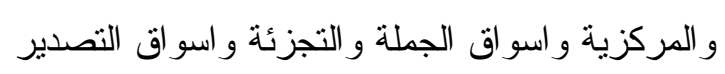

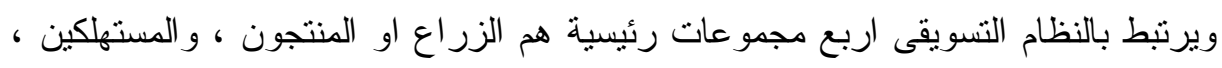

و الوسطاء النسويقيون ، واجهزة الدولة ومؤسساتها ، و عادة ما تتضارب الهتمامات هذة المجموعات التهات

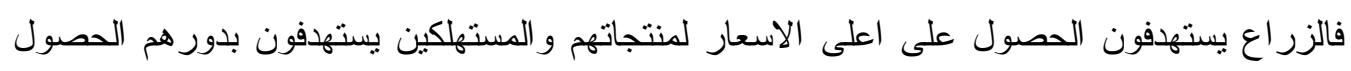

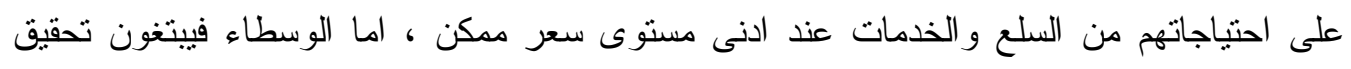

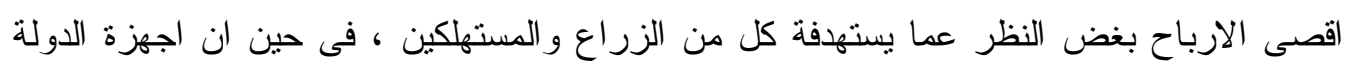

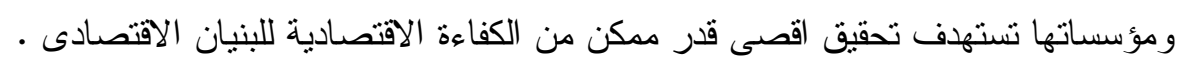
وتعتبر عملية تسويق القطن هي همزة الوصل بين المنتج و المستهلك على مختلف صور هم

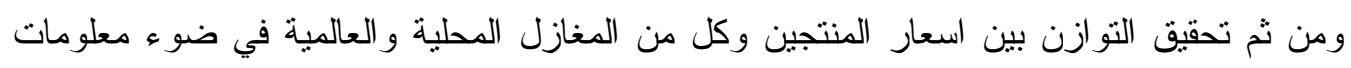
جيدة عن الانتاج و الاستهلاك و المخزون المحلي و العالمي، وهدف سياسة تسنة تسويق القطن تحقيق الكفاءة

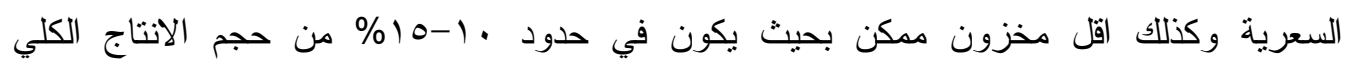

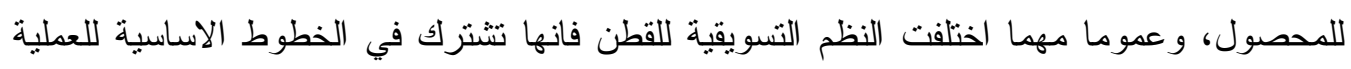
التسويقية والتي تبدا بزر اعة القطن ثم الجني ثم الحلج ثم التسويق المحلي و العالمي وذللك بما يتفق مع فئس السياسة العامة للاولة ويمكن حصر النظم التسويقية التاريخية للقطن في ثلاث مر احل رئيسية كما تلنيا 
1 ـ المرحلة الاولى ما قبل عام 197 ا : اتسمت هذه الفترة بان تسويق القطن داخليا وخارجيا كان يخضع لاليات السوق حيث كان التسويق حر بالنسبة لكافة الاجزة المتعاملة في سوق القطن

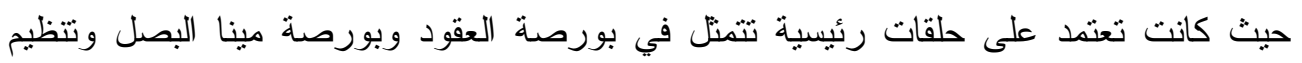
تجارة القطن بالداخل ثم اتحاد مصدري الاقطان.

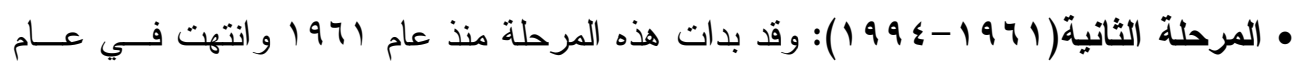

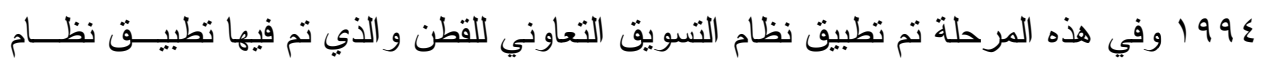

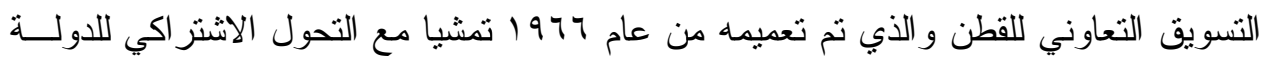

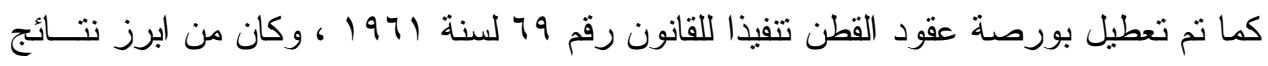

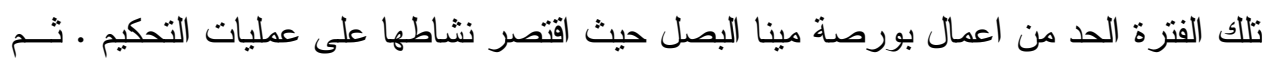
بدء تطبيق نظام التسويق التعاوني للقطن حيث ساد النظام الاشتر اكى في الدولة عموما و القطن

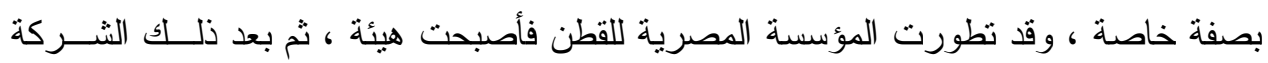

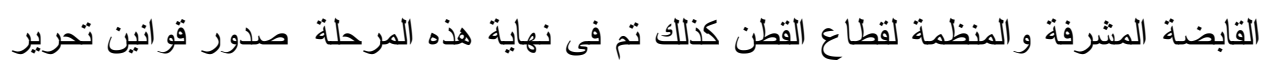
وتجارة القطن . دابن اهداف سياسة التسويق التعاوني للقطن: 1- ت تجنب جشع بعض التجار و الوسطاء. r- ابعاد عمليات المساومة التي يقف فيها المنتج موقف الضعيف نظر الثدة حاجة الثته للمال. r- حصول المنتج على السعر الحقيقي العادل للقطن عن طريق استبعاد الوسطاء من المسلك التسويقي للقطن قدر المستطاع.

اهم الاسس التي قام عليها نظام التسويق التعاوني:

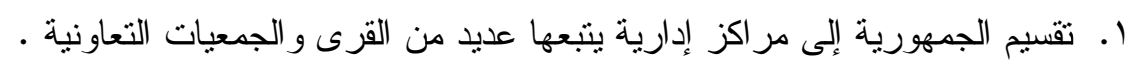

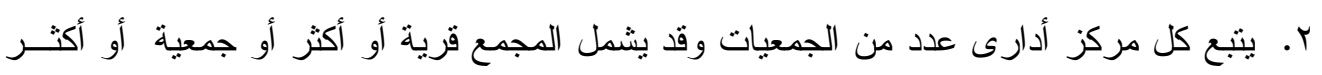
بحسب المساحة المنزر عة قطنا بكل قرية.

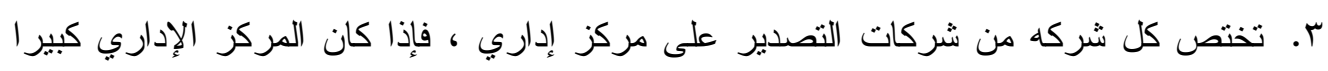
قسم إلي شركتين أو أكثز ير اعى في توزيع المراكز الإدارية على الثركات أن إستلاماتها ممثلكه في أصناف القطن المختلفة.

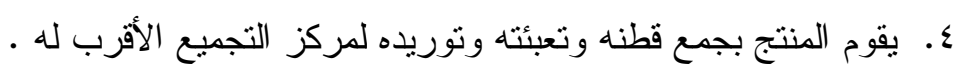

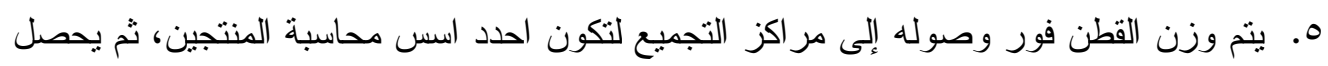

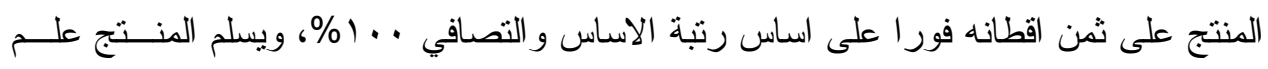

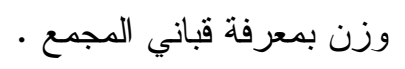
7. . ينم فرز القطن بمعرفة فرازي هيئه التحكيم، وتتحدد أسعار القطن بحسب الصنف و الرنبة التي

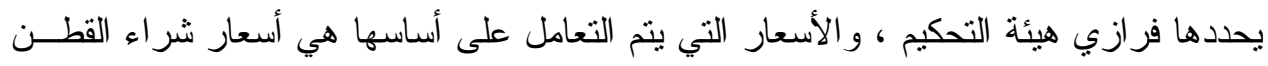

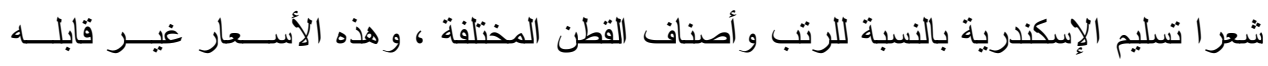

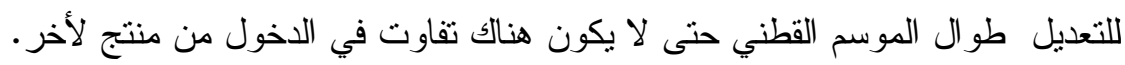




\section{اهم الخدمات التي يقدمها نظام التسويق التعاوني للزراع:}

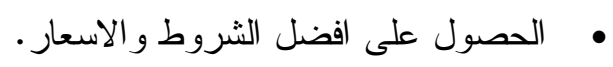

• رفع درجة النظافة و التعبئة الجيدة بما يساعد على رفع سع الحاصلات نتيجة للارشاد الذي

$$
\text { يقوم به مشرفو الجمعيات التعاونية. }
$$

$$
\text { • حصول المنتج على مستحقاته كاملة. }
$$

$$
\text { • توفير تكاليف الوسطاء في مختلف مر احل التسويق. }
$$

المشاكل التى واجهت نظام التسويق التعاوني:

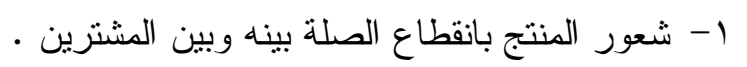

r- تكدس القطن وذلك لانتقاله من المنتج الى مر اكز التجميع وعدم ملاحقة الاجهزة المختلفة من بن بن

$$
\text { وزن وفرز وتقييم لمقابلة هذا التدفق السريع. }
$$

r- الاسر اف في استخدام الاكياس مما يؤدي الى اضافة تكلفة اضافية على المشتخلين بتسويق

القطن بالاضافة الى تعرض الاكياس الى القطع اكثر من مرة اثثاء عملية الفرز .

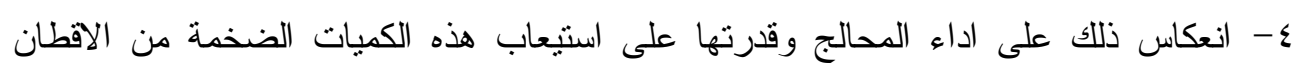

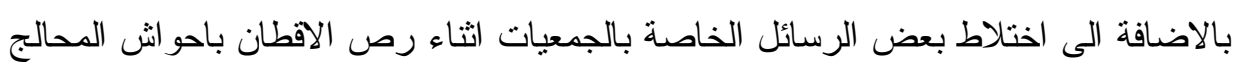

وبالتالي تدني رتب القطن لمستويات كانت محل شكوى المتعاملين في القطن بصفة عامة.

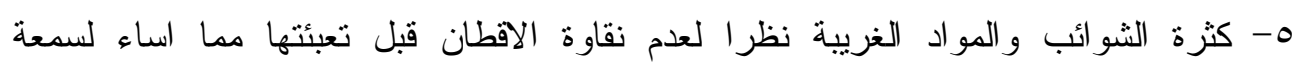

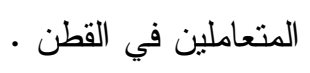

צ- قلة الرتب العالية من اصناف القطن المختلفة.

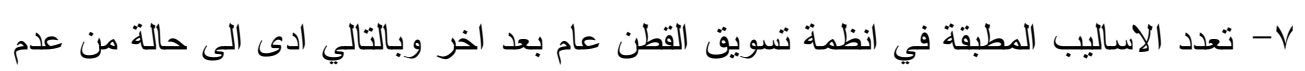

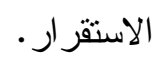

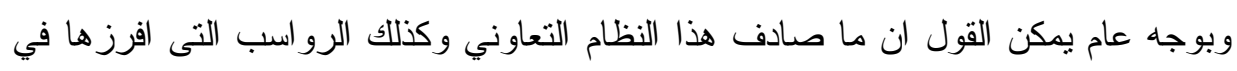

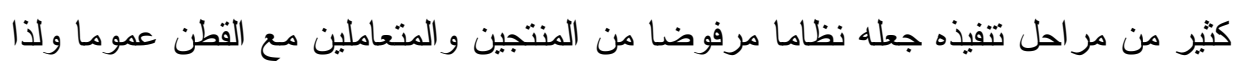

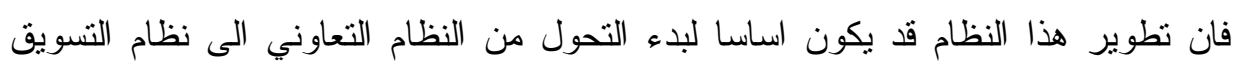

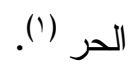

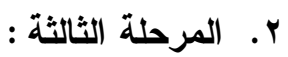

اتسمت هذه المرحلة بصدور قوانين تحرير تجارة القطن وذلك عن طريق اتباع اسلوب الاقتصاد الحر وذلك باصدار ثلاث تشريعات عام ـ99 19 لتنظيم تجارة القطن بالداخل وتدعيم اتحاد المصدرين واعادة احياء بورصة البضاعة الحاضرة للقطن (بورصة مينا البصل) وقد اكتمل تحرير المراحل المختلفة لتسويق القطن عام 1997

(1 ) عبدالمنعم محمود فاروق، تسويق القطن و الاجهزة المشتغلة به في الماضي و الحاضر ، اللجنة العامة لتنظيم تجارة 


\section{سياسة تسعير القطن المصري (')}

اهتمت الدولة بالقطن كمحصول استر اتيجي في اطار برنامج الاصلاح الاقتصادي وذلك منذ

عام \&990/9 حيث تم تطبيق سياسة تحرير تجارة القطن داخليا وخارجيا ، وتعتمد سياسة التسعير

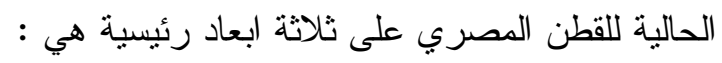
1- السياسة السعرية : و هي تتضمن كل من :

اسعار الضمان : و هي تتحدد بمعيار تكلفة الانتاج ونتسم بعدم الاستقر ار .

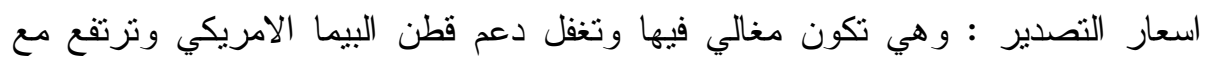
خفض تكاليف التسويق •

• المدفوعات التعويضية وهي عبارة عن طرح اسعار الضمان من اسعار التصدير. • r - النظام التسويقي المتبع حاليا: ويتسم بما يلى وهي عبلى

تخصيص حلقات التسويق اداريا بين القطاعين العام والخاص ولكن ذلك دون منافسة سعرية وبالتالي يكون في صالح القطاع العام.

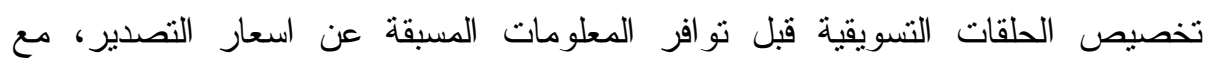
تخصيص كل حلقة نسويقية لمشتري و احد.

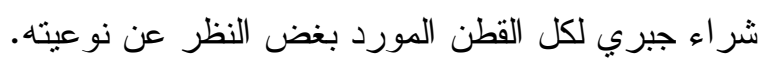
ب- الاطار المؤسسي لسوق القطن المصري: مع بدء سياسة الاصلاح الاقتصادي تقلص دور الحكومة في التخخل في عمليات الانتاج و التسويق و التجارة الخارجية اصبح هناك ثناث جهات للتعامل فى سوق القطن هي : مجلس القطن

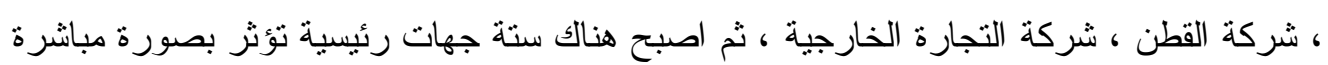

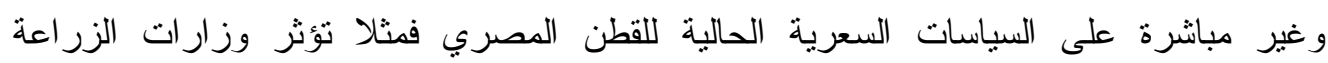
و التموين و الاقتصاد و الاعمال على كل من اسعار الضمان وتخصيص الحلقات التسويقية بصورة

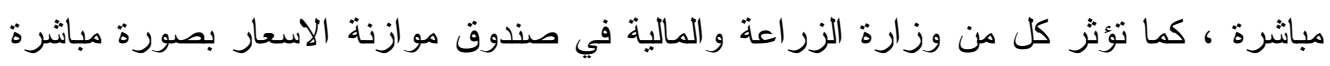

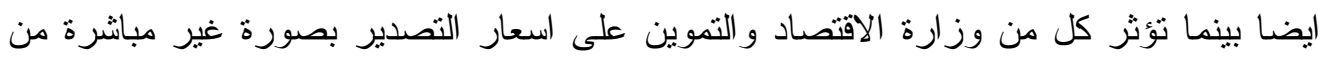
خلال اتحاد المصدرين. كما تز ايد الاهتمام بتوفير التشريعات التي توفر المناخ الملائم للتسويق بكفاءة عالية.

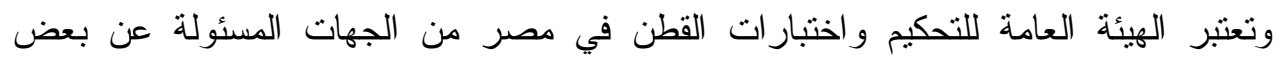

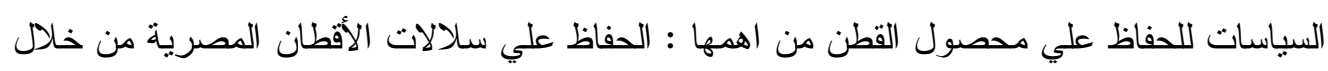
الصفات التكنولوجية لأصناف القطن في مواقع إنتاجه المختلفة علي مستوي جميع محافظات

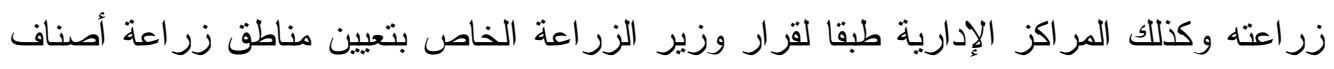
القطن لكل موسم بهدف الوقوف علي مدي الاختلاف فيما بين أصناف القطن وسلالته في الصفات

(1 ) امنية حلمي (دكثور) ، تامين الاقتصاد المصري ضد نقلبات الاسعار العالمية ،المركز المصرى للارسات

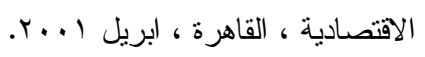


التكنولوجية في المراكز ، كما تقوم الهيئة بفرز الأقطان بنظام كبس وكيس وتقدير رنبة وسحب

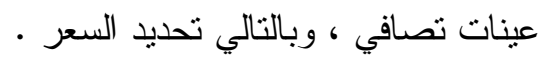

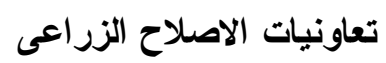

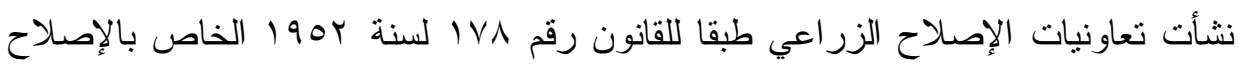

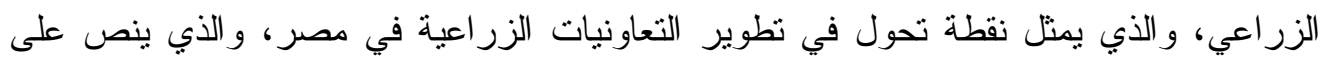

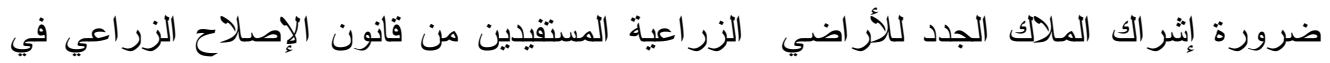
جمعيات تعاونية زر اعية تقوم بمساعدتهم في الحصول على مستلزمات الإنتاج وتتظيم الاستغلال

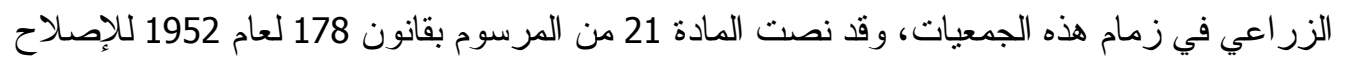
الزر اعي على أن تشترك التعاونية في تأسيس جمعيات عامة، و اتحادات تعاونية، وفقا لأحسات أحكام قانون

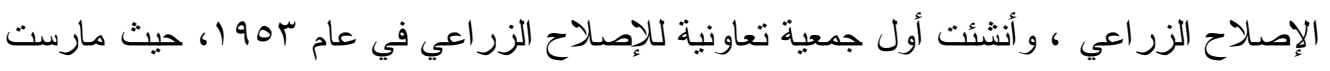

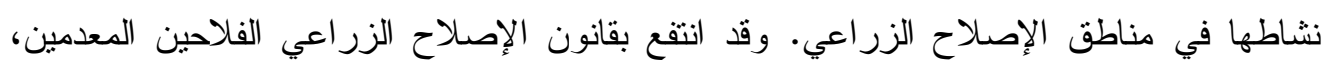

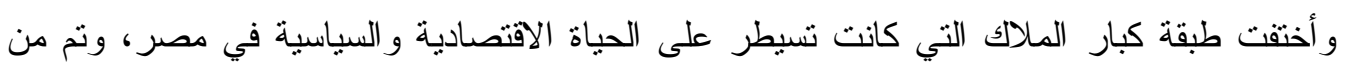
خلال التعاونيات معالجة عيوب تفتىت الملكية نتيجة لتوزيع الأر اضي وذلك عن طريق التجميع

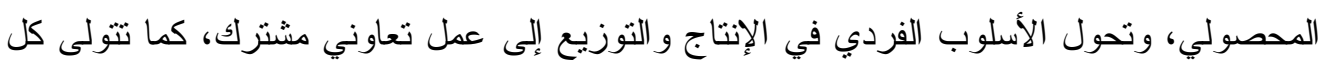

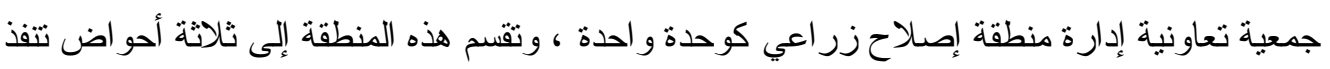

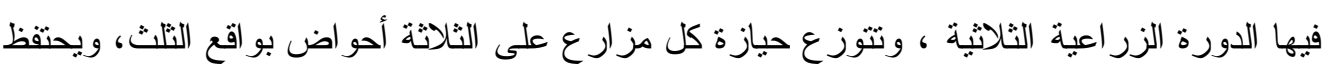

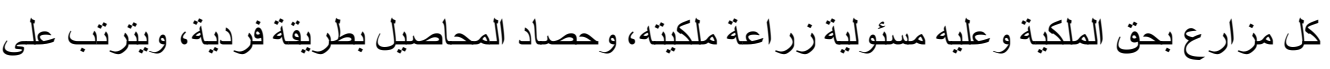
قيام التعاونيات بممارسة أنشطتها الزر اعية وغير ها تحقيق وفور اتيه ات الحجم الكبير وضمان حسن الأداء

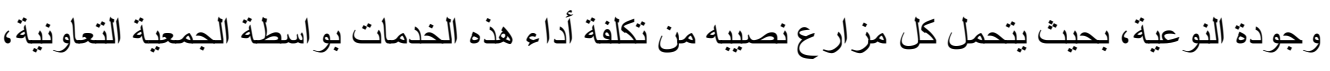

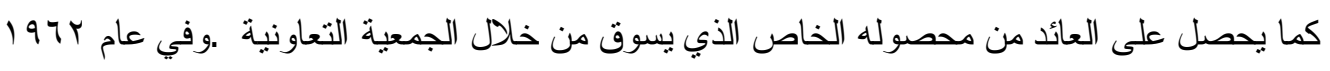

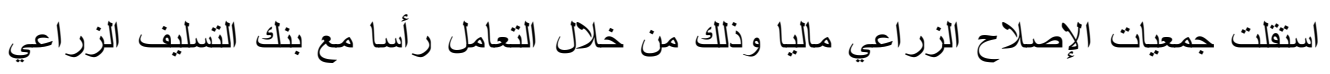

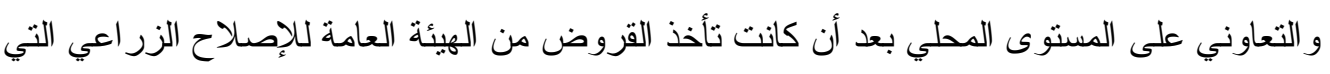
كانت تقدم من بنك التسليف الزر اعى . ويعتبر من أهم ملامح نعاونيات الإصلاح الزر اعي دورها القيادي بالنسبة لباقي التعاونيات في

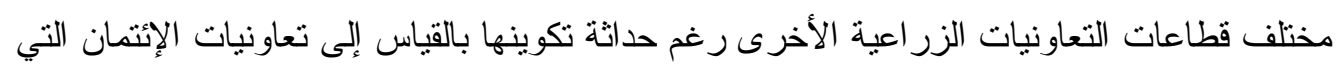

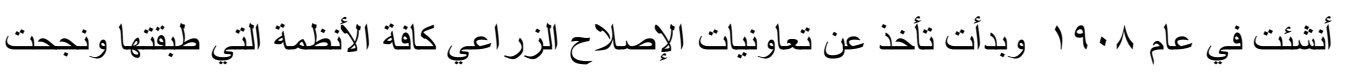
فيها، وتعتبر جمعيات الإصلاح الزراعي أول من طبق نظام التسويق التعاوني بجمعيات الإصلاح

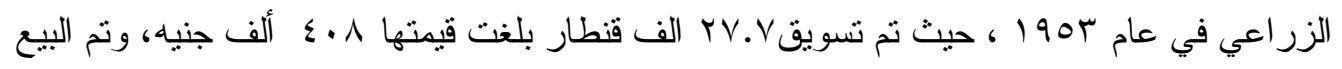
عن طريق جلسات المز اد التي كانت تعقد في مقر الهيئة العامة للإصدلاح الزر اعي بالقاهرة، وكانت

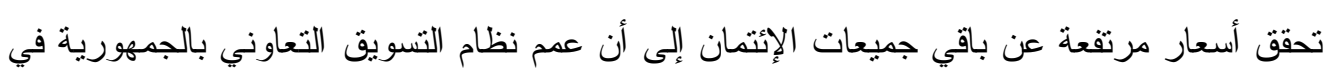




\section{الهيكل التظيمى والادارى للهيئة العامة للاصلاح الزراعى}

يقسم البنيان التعاونى الى مجموعة من الوحدات التعاونية التى يحققها النظام التعاونى و ذلك التك بغرضه الاساسى لتحقيق التكامل الراسي فى التعاون حتى يتحقق تحسين الاداء التعاونى لقوة الجهاز

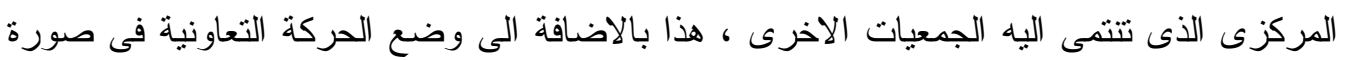

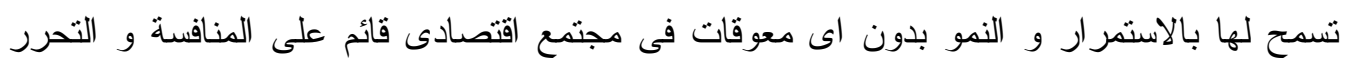
الاقتصادى.

يوضح الجدول رقم (r) الهيكل التنظيمى و الادارى للهيئة العامة للاصلاح الزر اعى حيث يتبين

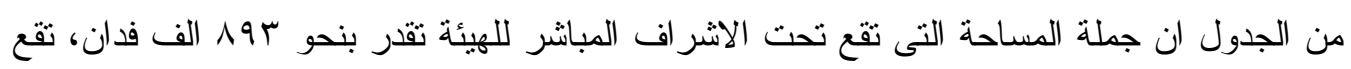

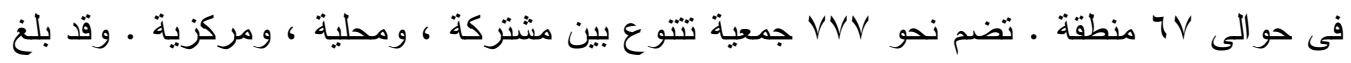

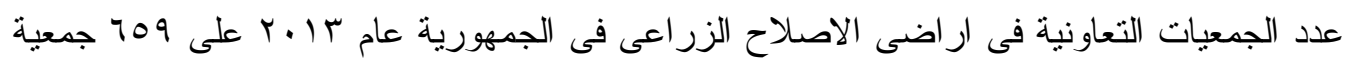

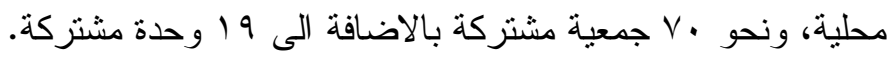

جدول رقم (r) الهيكل التتظيمى والادارى للهيئة العامة للاصلاح الزر اعى (r • ب)

\begin{tabular}{|c|c|c|c|c|c|c|c|}
\hline \multirow{2}{*}{ الاجمالى } & \multicolumn{3}{|c|}{ عدد الجمعيات } & \multirow{2}{*}{ عدد المناطق } & \multirow{2}{*}{ جملة المساحة } & \multirow{2}{*}{ المديرية } & \multirow{2}{*}{ r } \\
\hline & المركزية & المشتركة & المحلية & & & & \\
\hline 19 & 1 & r & 17 & r & A.TAr & الاسكندرية & 1 \\
\hline $10 r$ & 1 & ir & 149 & ir & $1 \wedge \wedge 0 \leqslant V$ & البحيرة & r \\
\hline $7 \varepsilon$ & 1 & $\varepsilon$ & 09 & $\varepsilon$ & V\9VA & كفر الثيخ & r \\
\hline 97 & 1 & 7 & 19 & 7 & 99011 & الدقهلية & $\varepsilon$ \\
\hline IV & 1 & r & $1 \varepsilon$ & r & IVITY & دمياط & 0 \\
\hline 94 & 1 & $\wedge$ & N & $\wedge$ & $907 r \leq$ & الثرقية & 7 \\
\hline$\leqslant \wedge$ & 1 & $\varepsilon$ & $\varepsilon r$ & $\varepsilon$ & $\varepsilon \cdot r \wedge q$ & الغربية & v \\
\hline TV & 1 & r & $r \varepsilon$ & r & IVarA & المنوفية & $\wedge$ \\
\hline 9 & 1 & 1 & v & 1 & $11 \leq 11$ & الاسماعيلية & 9 \\
\hline 11 & 1 & r & 10 & r & $\mid r 011$ & القليو بية & 1. \\
\hline 19 & 1 & r & 17 & r & 1 & الجيزة & 11 \\
\hline TY & 1 & $r$ & Tr & $r$ & rาq & بنى سويف & IT \\
\hline די & 1 & $r$ & rt & $r$ & $O Y I \leq A$ & الفيوم & 14 \\
\hline v. & 1 & 7 & זד & 7 & $V O V \leqslant r$ & المنيا & $1 \leqslant$ \\
\hline 17 & 1 & $r$ & ir & $r$ & $19 \leq 77$ & اسيوط & 10 \\
\hline ir & 1 & 1 & 1. & 1 & $1.90 r$ & سو هاج & 17 \\
\hline$r$ r. & 1 & $r$ & IV & r & $(1) \leq q 1$ & قنا & IV \\
\hline 11 & 1 & $r$ & $1 \varepsilon$ & $r$ & rIVO0 & الاقصر & 11 \\
\hline 11 & 1 & 1 & 17 & 1 & 100rr & اسوان & 19 \\
\hline VVV & 19 & TV & 791 & TV & А & جمالى & \\
\hline
\end{tabular}

المصدر : جمعت وحسبت من بيانات الادارة العامة للمعلومات و التوثيق ، و ادارة التعاون ، العيئة العامة للاصلاح الزر اعى ؟ ا. . . 
كما تبين من الجدول السابق الاشارة اليه ان محافظة البحيرة نأتى فى المرتبة الاولى من حيث

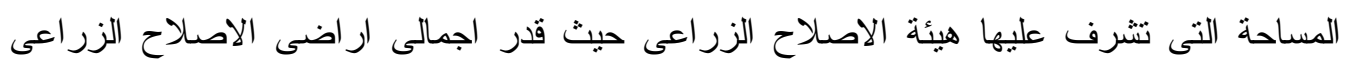

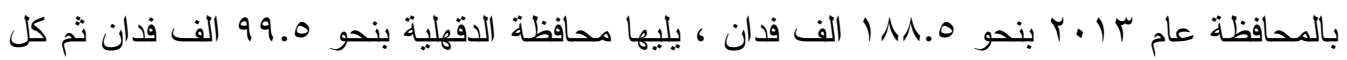

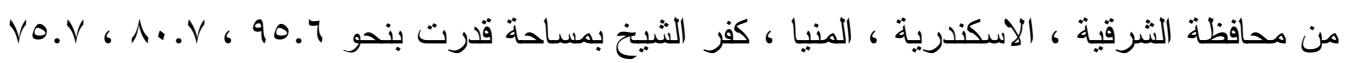

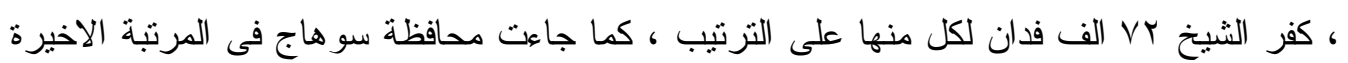

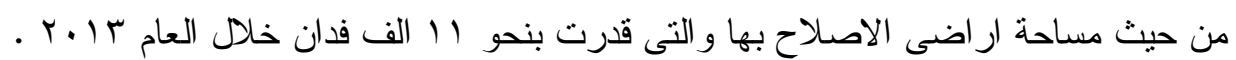

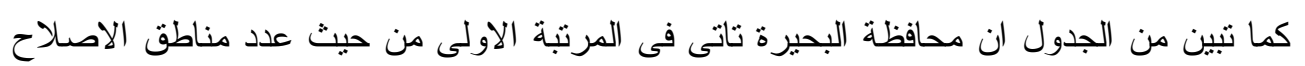

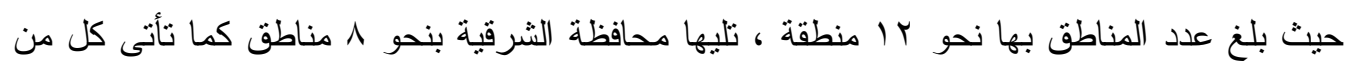

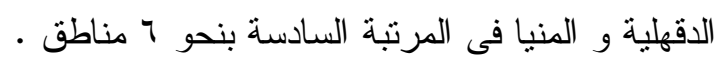

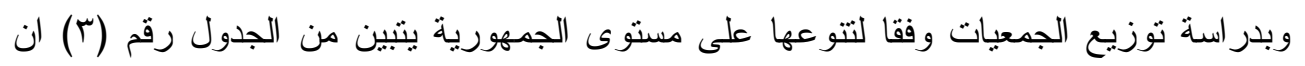
محافظة البحيرة تأتى فى المرتبة الاولى من حيث عدد الجمعيات حيث قدر عدد الجمعيات بها بنحو

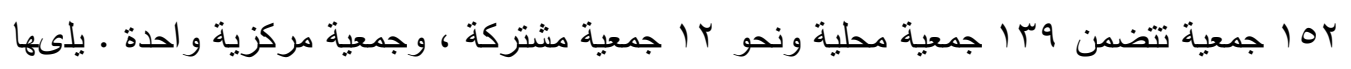

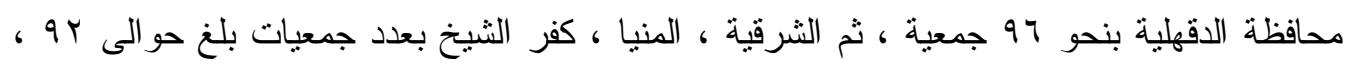
.

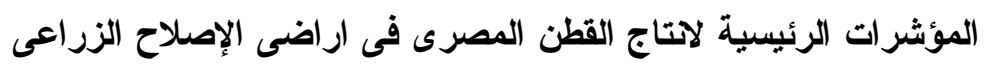

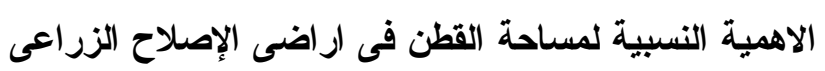

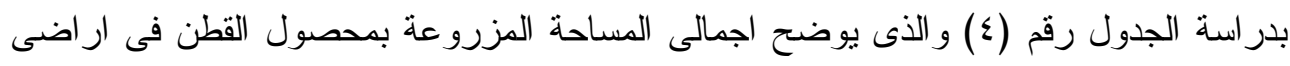

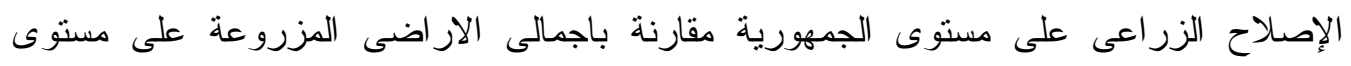

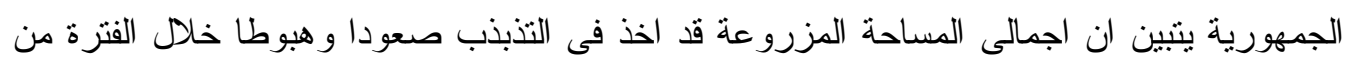

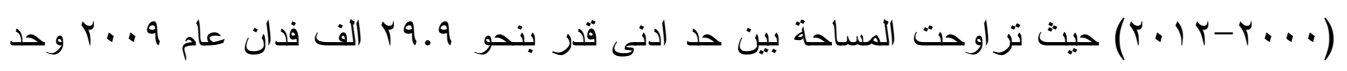

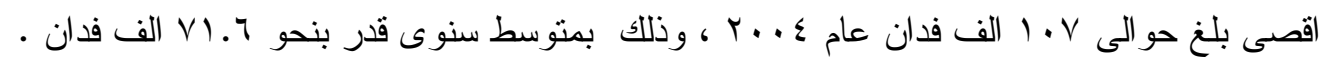
وبدراسة الاهمية النسبية لاجمالى المساحة المزروعة من محصول القطن بار اضى الإصلاح

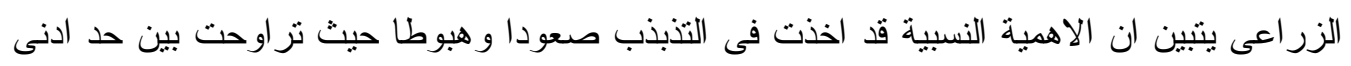

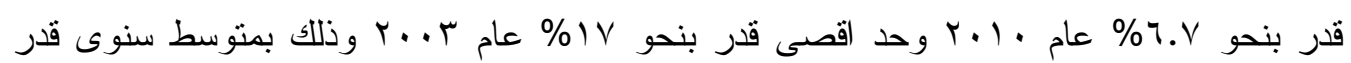
بنحو سוر بان وفي إطار برنامج الإصلاح الاقتصادي تم تحرير إنتاج وتجارة القطن بهدف زيادة الإنتاج

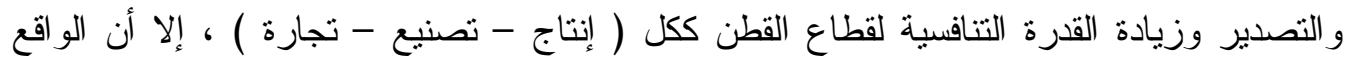
أنشار إلي عكس ذللك حيث تتاقصت مساحة القطن سنة بعد آخري ، وانخفضت أهميته النسبية في

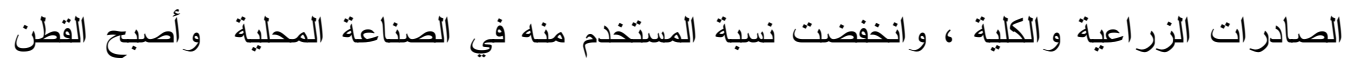

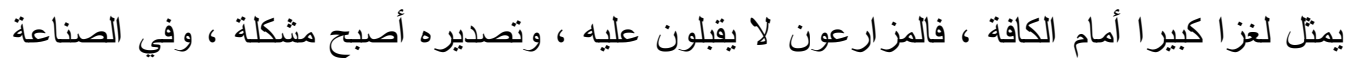

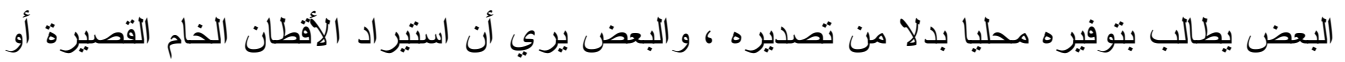


متوسطة التيلة أفضل للصناعة المحلية ، البعض يطالب بدعم الإنتاج حفاظا علي مكانة القطن ، و البعض الأخر يعتبر ذلك تخلفا ، وهو ما خلق حالة من الجدل الثديد حوله.

جدول رقم (ع) الاهمية النسبية للمساحة القطنية لار اضى الاصلاح الزراعى الى اجمالى المساحة

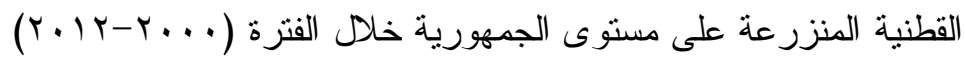

المساحة : بالالف فدان

\begin{tabular}{|c|c|c|c|}
\hline المنزرعة فى ار اضى الاصية النسبية لمساحة القطن & مساحة القطن على مستوى اراضى الاصلاح الزر اعي & اجمالى مساحة القطن على & السنة \\
\hline 17.8 & ᄉ.. & $011 . r$ & $r \ldots$ \\
\hline $1 \varepsilon$ & I. T. Y & VTI.I & $r \ldots l$ \\
\hline I $\varepsilon . V$ & I.T.V & $V .7 . \varepsilon$ & $r \ldots r$ \\
\hline IV & $91 . r$ & oro.1 & $r . . r$ \\
\hline 10 & $1 \cdot v$ & $V) \leq . V$ & $r \ldots \varepsilon$ \\
\hline I ¿.V & 97. & 707.1 & $r \ldots o$ \\
\hline Ir.V & Vr.V & ע. & $r \ldots T$ \\
\hline 15.0 & VV.A & $0 \vee \varepsilon .7$ & $r \ldots v$ \\
\hline $10 . r$ & $\varepsilon V . V$ & r.V.V & $r \ldots$ \\
\hline $1 \cdot .0$ & rq.9 & 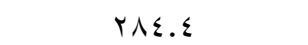 & $r . . q$ \\
\hline 11.19 & $\varepsilon 1 . r$ & & $r .1$. \\
\hline 7. & $r \varepsilon . V$ & or..Ir & $r .11$ \\
\hline 11.0 & rq. & $r \varepsilon . . V$ & $r .1 r$ \\
\hline $1 T, \cdot \Lambda$ & VI,Tr & QTT,IE & المتو سط \\
\hline
\end{tabular}

المصدر : وزارة الزر اعة ، قطاع الثئون الاقتصاد الزر اعي ، الإدارة المركزية للاقتصاد الزر اعي ، نشرة الاقتصاد الزر اعي، اعداد مختلفة.

ويوضح الجدول رقم (0) تطور المساحة والانتاج والانتاجية لمحصول القطن فى اراضى

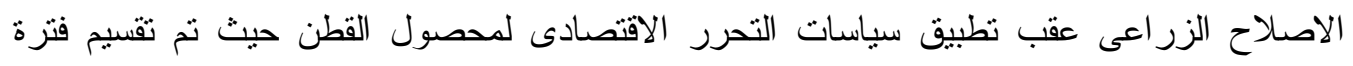

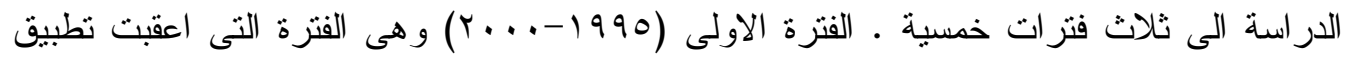

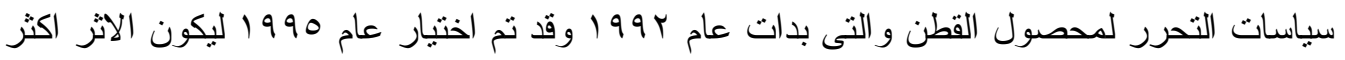

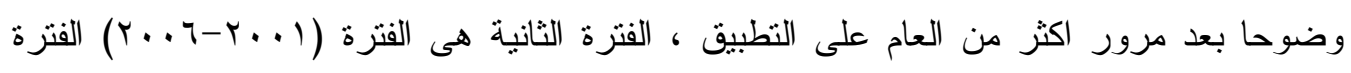

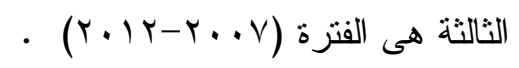
المساحة المزروعة

حيث يتبين من الجدول رقم (0) ان المساحة المزوعة قد اخذت فى التذبذب صعودا وهبوطا

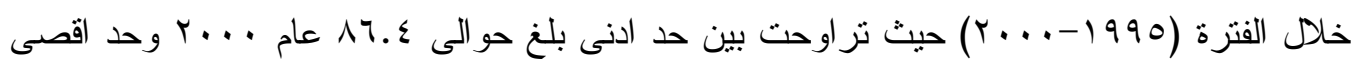

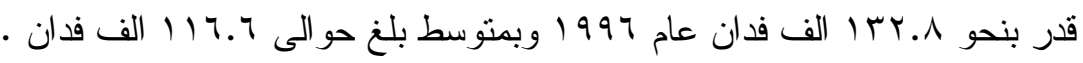




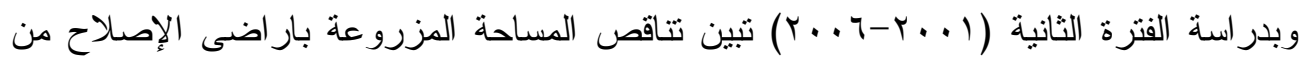

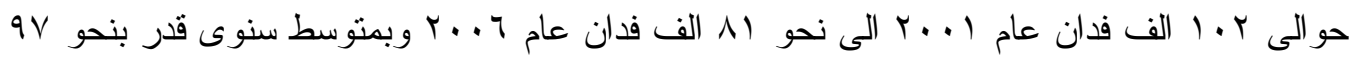

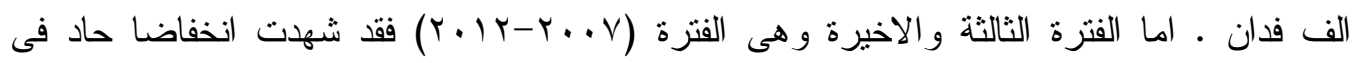
المساحات المزروعة بالقطن فى ار اضى الإصلاح مقارنة بالفترتين السابقتين حيث تر اوحت المساحة

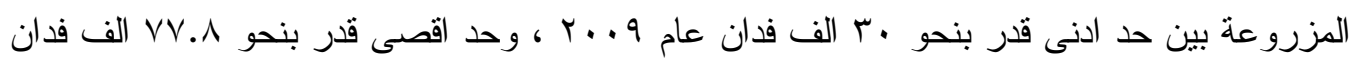

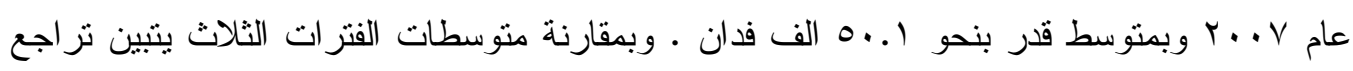

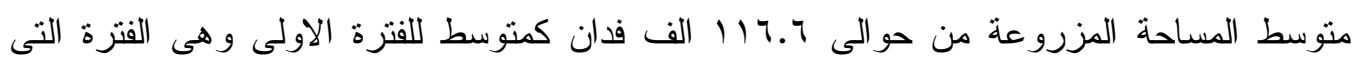

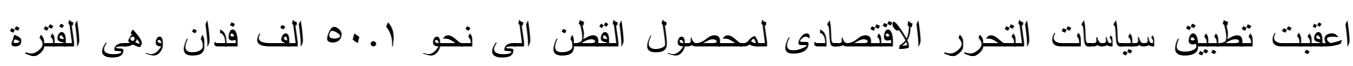

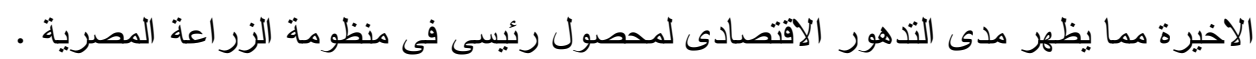

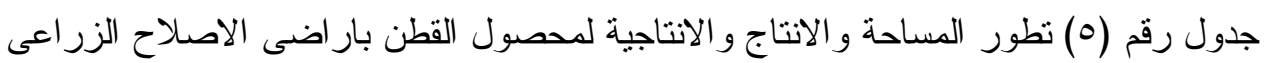

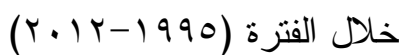

\begin{tabular}{|c|c|c|c|c|c|c|c|}
\hline صافى العائد & الاجمالى الير & المزرعى السعر & جنيا التيف & بالألت فناج الكلى & قنطار / فدان & بالألف فدان & السنو ات \\
\hline IVY9.0 & YIV9.0 & r $\leqslant 0 Y .1$ & $1 \leq 0$. & AVr, r & $V, r$ & 119.0 & 1990 \\
\hline 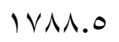 & rTVI.V & $r Y \leqslant V$ & $1 \leqslant \wedge \wedge . r$ & $1 \cdot r O, A$ & $\checkmark, \Lambda$ & ITr.A & 1997 \\
\hline ITVY & rYqА. & r..r.r & 17 17.1 & 1.49 .7 & $\checkmark, q$ & $|r| .7$ & 1998 \\
\hline rVV & 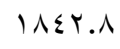 & Tr10.r & ג.זדצו & $\Lambda \varepsilon Y, q$ & 7,1 & IrE,Y & 1991 \\
\hline $00 \leqslant . \varepsilon$ & הוזqR. & rrio.r & 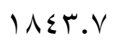 & Trr., & 7 & $1 \cdot \xi, 1$ & 1999 \\
\hline 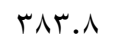 & $r \leqslant r$ T.V & rTr.V & r.or & $7 \cdot r, 1$ & 7,9 & $\wedge \uparrow, \xi$ & r... \\
\hline $1.78,7$ & rovr & rYol, & $17 A Y, 0$ & $\Lambda F \wedge, A$ & $v, 1$ & 117.7 & متوسط الفترة \\
\hline orA.o & ro97.0 & rOTI & $r .7 \wedge$ & 107,7 & A,\& & I.Y,Y & r... \\
\hline Nrq & rAqr & $r \wedge . q$ & rT. & Vฯ9,1 & Y, ₹ & I.r.Y & r..r \\
\hline IVos & r人тo & r人тo & 111 & OrY,Y & 0,1 & $91, r$ & r..r \\
\hline IVVT & & ए人тV & 119. & var, I & V.₹ & $1 \cdot v$ & r..\& \\
\hline$r .01$ & $\sum T \vee 0$ & $\leqslant 009$ & YTIV & $\{7 \leqslant .7$ & $\xi . \Lambda$ & $97, r$ & r..o \\
\hline rד19 & $070 \leqslant$ & oors & r970 & $m 90,1$ & $\xi, 9$ & Al & $r . . q$ \\
\hline $17 \cdot 0, r$ & एव६। & सATI,O & rrro, & $7 r+.1$ & 7.0 & 97.9 & متوسط الفترة \\
\hline 1499 & EVTদ & $\leqslant 7 . r$ & $r \leq r v$ & rav & 0 & $\checkmark Y, A$ & $r \cdots r$ \\
\hline سדו & Tr人q & Trot & $\varepsilon \leqslant 07$ & TIr.T & 7,0 & $\xi \vee, \vee$ & $r \cdots 1$ \\
\hline STAI & NAOr & 人 $79 V$ & sov1 & $\mathbb{1 A}\{, 9$ & $7 . r$ & $r 9,9$ & r..q \\
\hline rrio & $\wedge \varepsilon \cdot \wedge$ & Nrol & & rro, \& & 7.V & $\$ 1,1$ & r.l. \\
\hline IrrT & TVIT & roro & $0 \leqslant 9$. & EYY,Y & 7,9 & $9 r .1$ & r.11 \\
\hline rrq. & $v \cdot 19.7$ & 7191 & $\{7 r 9, \xi$ & rVq,乏 & 7.8 & $\xi 1, V$ & $r \cdot 1 r$ \\
\hline IVYq.0 & YIV9.0 & reor. 1 & $1 \leqslant 0$. & rII.r & T.rr & $0 ., 00$ & متوسط الفترة \\
\hline $17 \leqslant 7, r$ & \{rqr,r & \&TO\& & PrAl,O & OAT,YE & 7,7 & $\wedge \vee, q$ & المتوسط العام \\
\hline
\end{tabular}

المصدر : جمعت وحسبت من التقرير السنوى الاحصائى لانشطة الهيئة، الادارة العامة للمعلومات و التوثيق،الهيئة العامة للاصلاح الزر اعى با بr 
ويوضح الجدول رقم (7) معادلة الاتجاه الزمنى العام للمساحة المزروعة بمحصول القطن فى

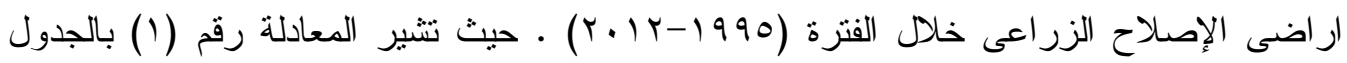

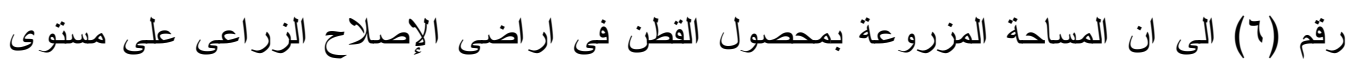

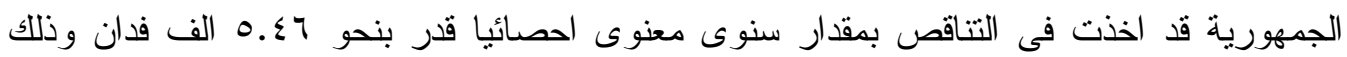

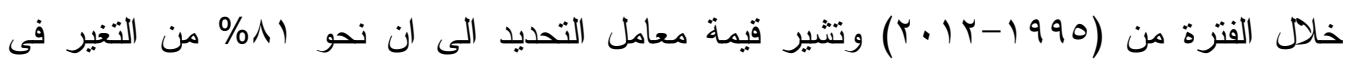

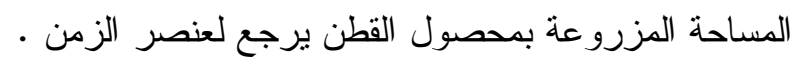

جدول رقم (؟) معادلات الاتجاه الزمنى العام للمؤشر ات الاقتصادية لمحصول القطن فى ار اضى

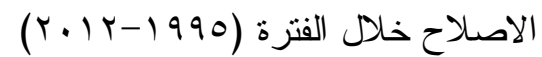

\begin{tabular}{|c|c|c|c|c|}
\hline $\mathrm{F}$ & $R^{2}$ & المعادلة & البيـــــــــــان & b \\
\hline VT.T & $0 . \wedge 1$ & $Y=1 \leqslant 0-0 . \leqslant 7 X$ & \multirow{2}{*}{ المساحة المزروعة } & \multirow[b]{2}{*}{1} \\
\hline & & $(-\wedge .07)^{* *}$ & & \\
\hline \multirow[t]{2}{*}{ oג.r } & $0 . v v$ & $Y=1 . r \leq-\leq 0 . r X$ & \multirow{2}{*}{ الانتاج الكلى } & \multirow{2}{*}{2} \\
\hline & & $(-\vee . \neg)^{* *}$ & & \\
\hline \multirow[t]{2}{*}{ r.o } & $0 . r$. & $Y=V . \varepsilon-. \cdot 1 X X$ & \multirow{2}{*}{ الانتاجية الفدانية } & \multirow{2}{*}{3} \\
\hline & & $(-1.9)^{* *}$ & & \\
\hline \multirow[t]{2}{*}{$1 \ldots$} & $0 . \wedge T$ & $Y=r 11+r r q X$ & \multirow{2}{*}{ التكاليف الكلية } & \multirow{2}{*}{$\varepsilon$} \\
\hline & & $(1 . .1)^{* *}$ & & \\
\hline \multirow[t]{2}{*}{ « } & $0 . V r$ & $Y=1 r 70+r r q X$ & \multirow{2}{*}{ السعر المزرعى } & \multirow{2}{*}{ 。 } \\
\hline & & $(\neg . \varepsilon)^{* *}$ & & \\
\hline \multirow[t]{2}{*}{07} & $0 . v V$ & $Y=1 \cdot V \lambda+m u X$ & \multirow{2}{*}{ اجمالى الاير اد } & \multirow{2}{*}{ 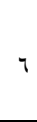 } \\
\hline & & $(\mathrm{v} .0)^{* *}$ & & \\
\hline \multirow[t]{2}{*}{7.7} & $0 . r$. & $Y=v .7+1 . r X$ & \multirow{2}{*}{ صافى العائد } & \multirow{2}{*}{ v } \\
\hline & & $(r .0)^{* *}$ & & \\
\hline
\end{tabular}

المصدر : جمعت و حسبت من الجدول رقم (0) بالبحث

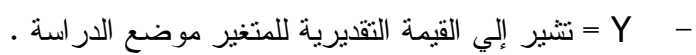

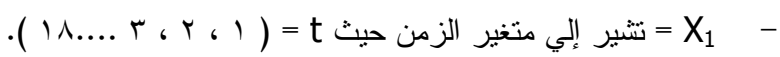

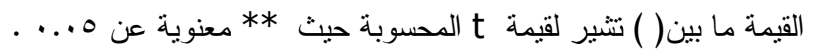
الاتتاج الكلى مانى

يوضح الجدول رقم (0) ان كمية الانتاج من القطن قد اخذت فى التذبذب صعودا وهبوطا خلال

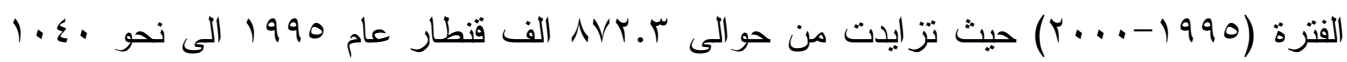

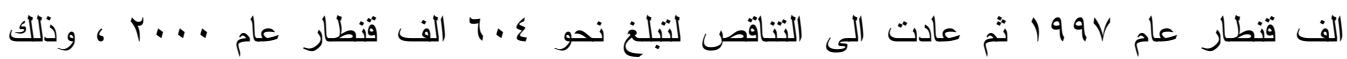

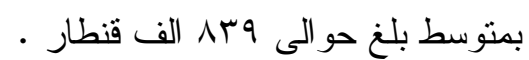

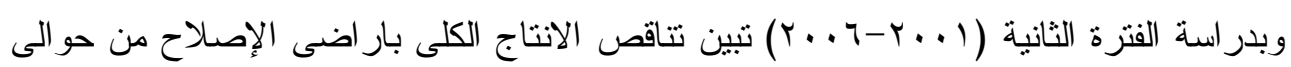

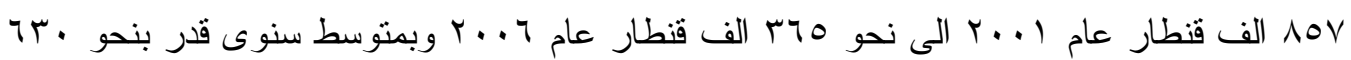




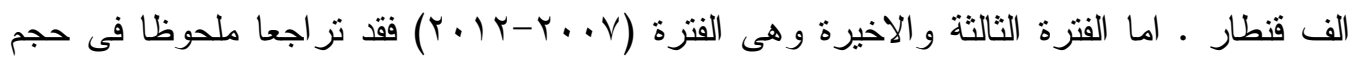
الانتاج نظر التزاجع المساحات المزروعة بالقطن فى اراضى الإصلاح مقارنة بالفترنين السابقتين

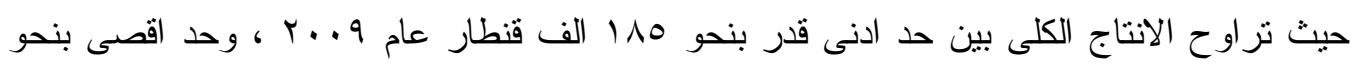

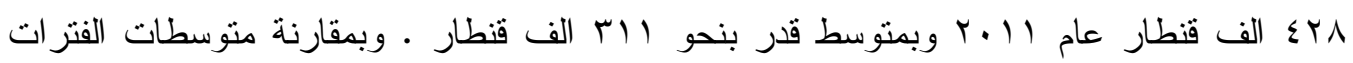

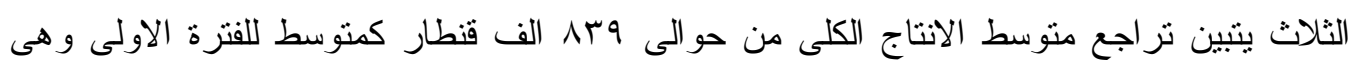

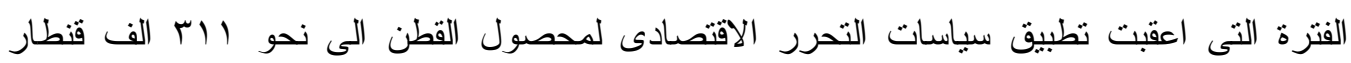

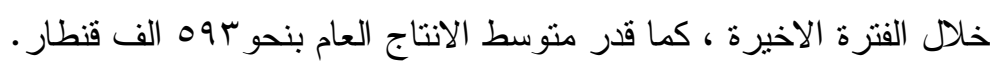

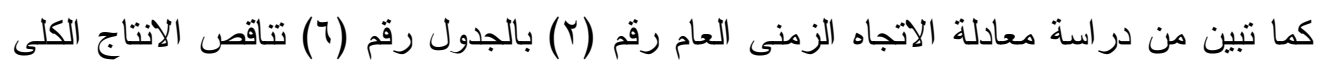

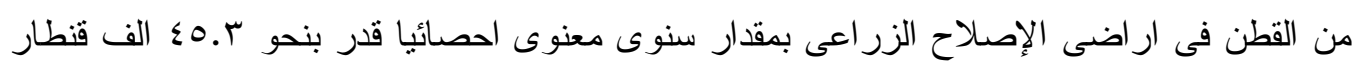

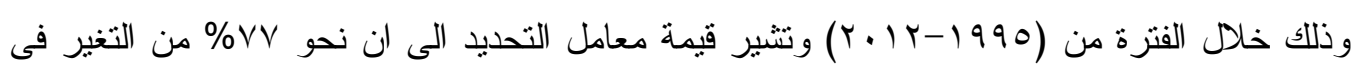
الانتاج الكلى من محصول القطن يرجع لعنصر الزمن.

\section{الانتاجية الفدانية}

بدراسة الجدول رقم (0) بالدراسة يتبين ان الانتاجية الفدانية من محصول القطن فى ار اضى الإنه

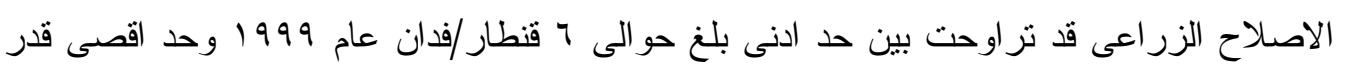

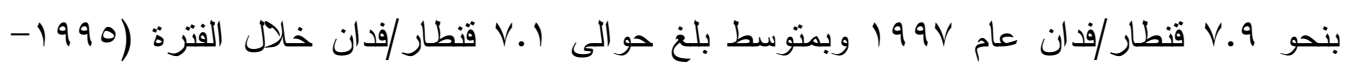
. (r...

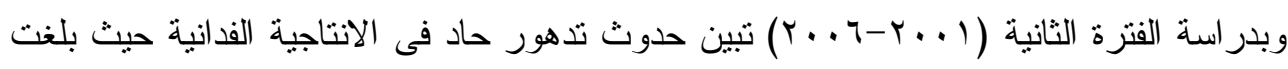

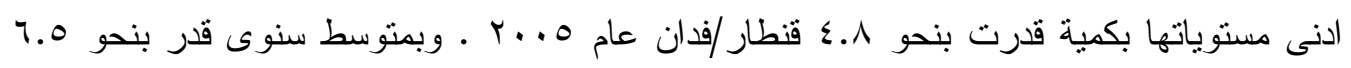

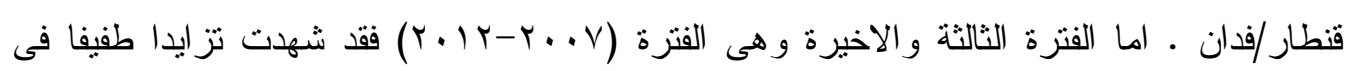
الانتاجية الفدانية وان كانت لم ترجع لمستو اها فى الفترة الاولى حيث نز ايدت الانتاجية الفئرة الفدانية من

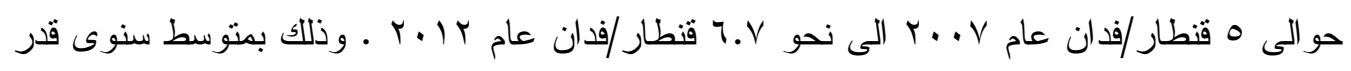

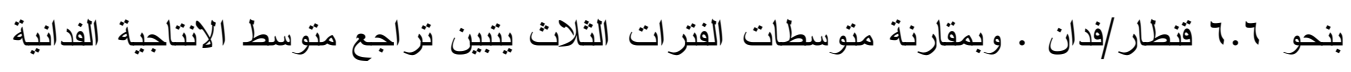

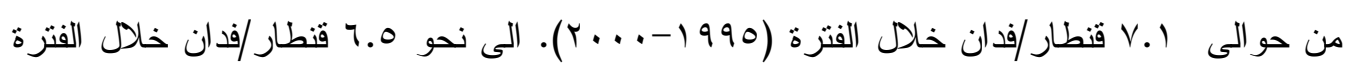
الثانية ، ثم الى نحو هـ ـا قنطار /فدان فى الفترة الثالثة و الاخيرة وتثير معادلة الاتجاه العام رقم (ץ) بالجدول رقم (؟) الى لتى تتاقص الانتاجية الفدانية من محصول

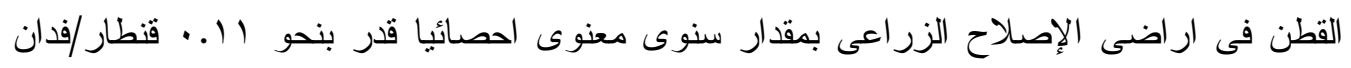

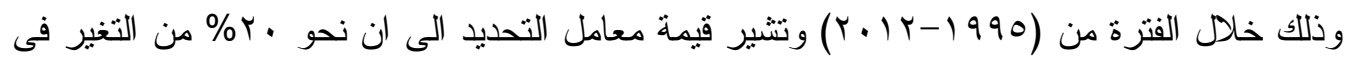
الانتاجية الفدانية برجع لعنصر الزمن التكاليف الاتتاجية

يوضح الجدول رقم (0) ان التكاليف الانتاجية للفدان من القطن قد اخذت فى التز ايد خلال الفترة

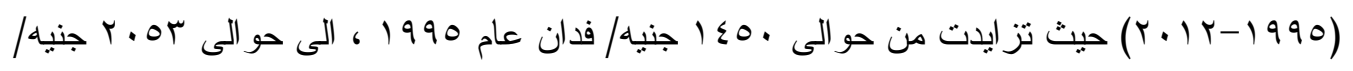

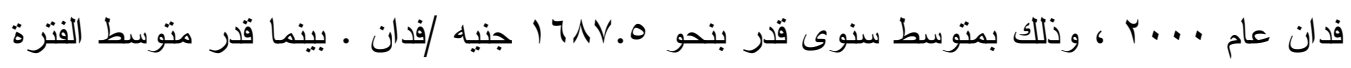

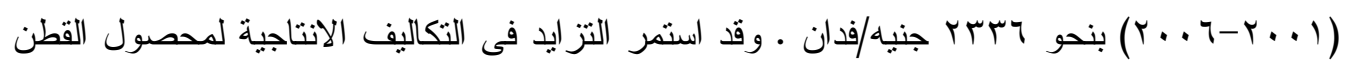




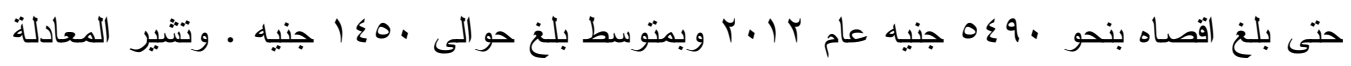

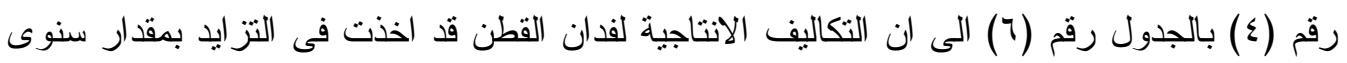

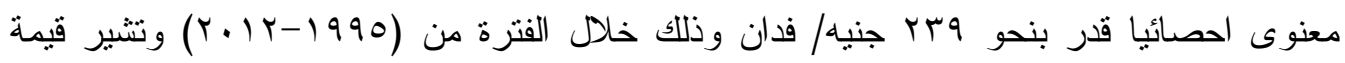

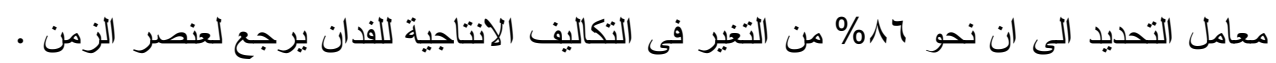

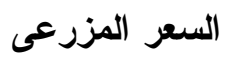
بدر اسة الجدول رقم (0) يتبين ان السعر المزرعى لمحصول القطن اخذ فى التذبذب صعودا

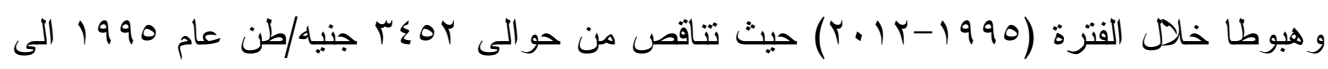

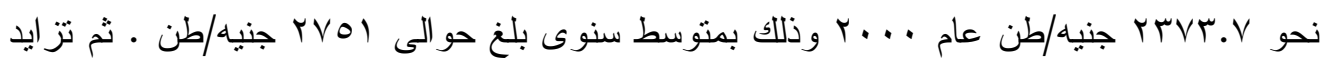

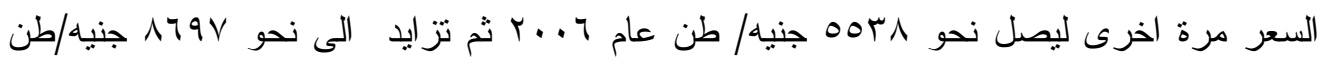

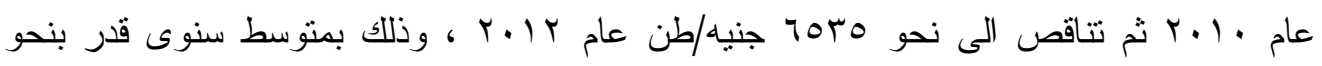

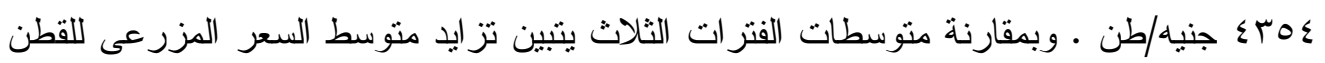

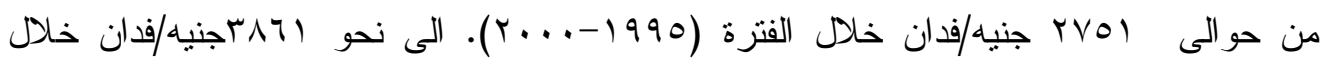

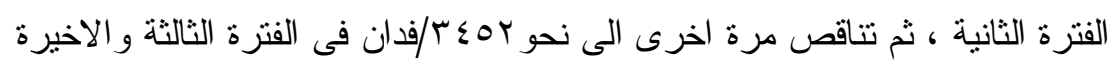

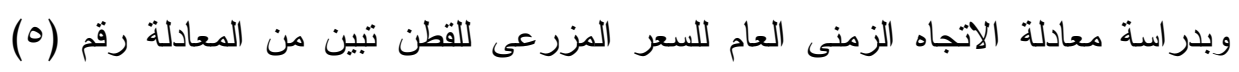
بالجدول رقم (7) ان السعر المزرعى للطن من محصول القطن قد تزايد بمقدار سنوى معنوى

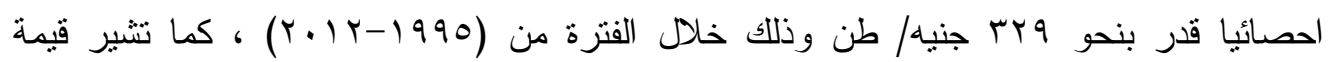

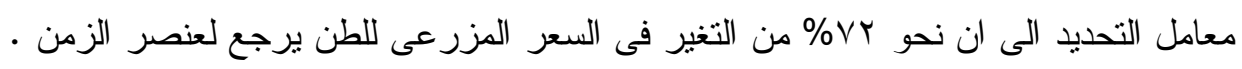
اجمالى الايراد

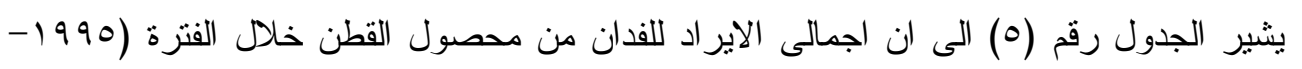

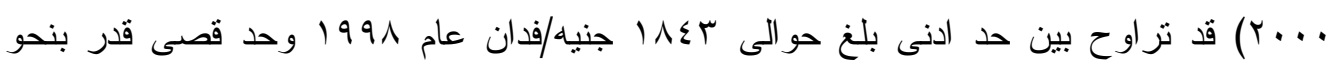

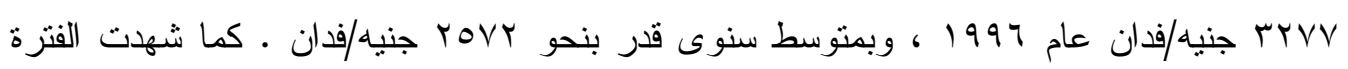

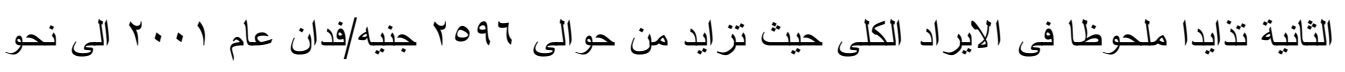

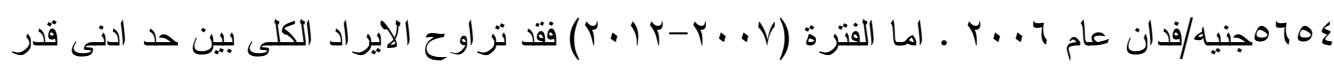

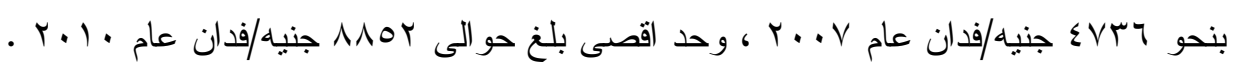

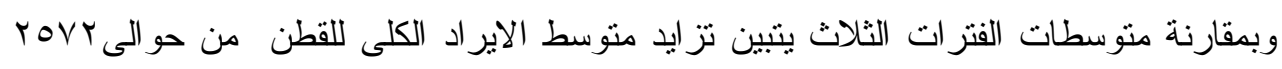

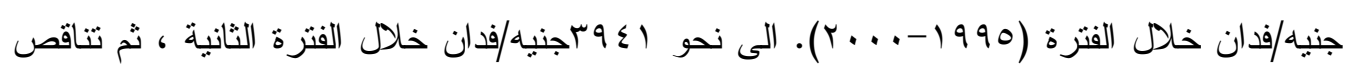

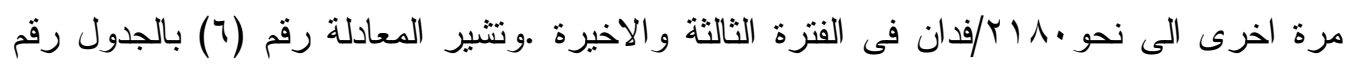

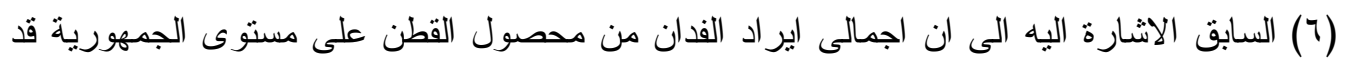

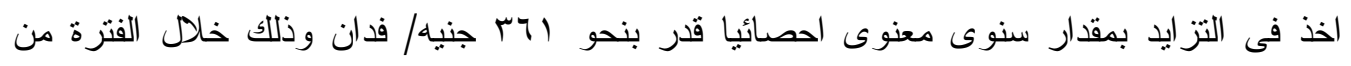

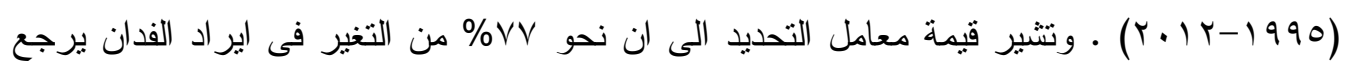




\section{صافى العائد}

بدر اسة صافى العائد الفدانى لمحصول القطن خلال الفترة (1990-.... ب) وهى الفترة التى اعقبت نطبيق سياسات التحرر الاقتصادى على محصول القطن ينبين من الجدول رقم (0) ان صافى

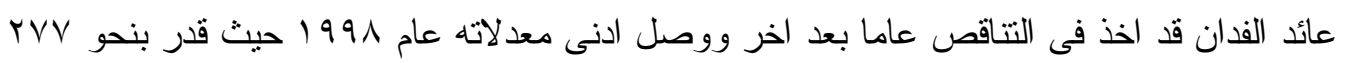

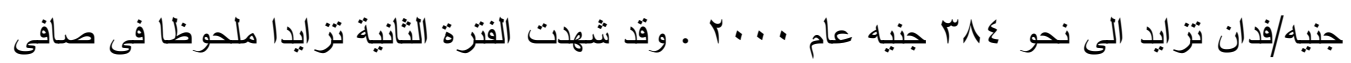

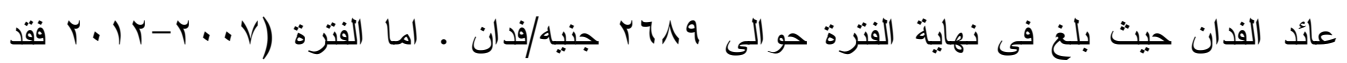

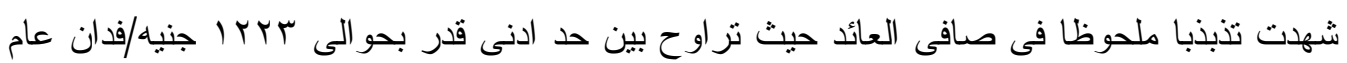

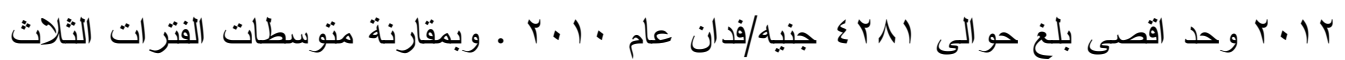

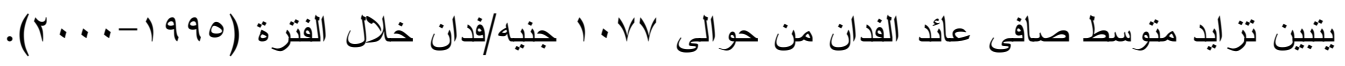

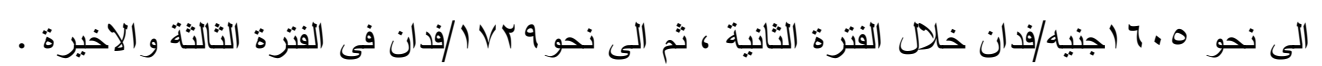

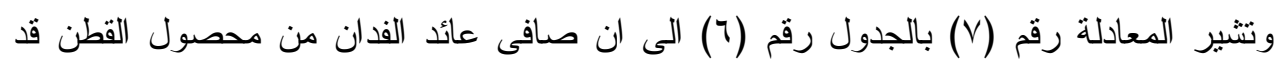

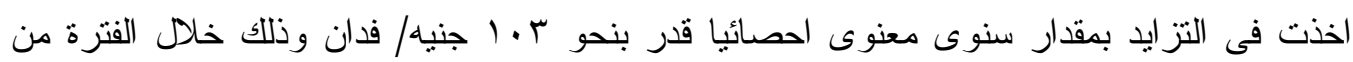

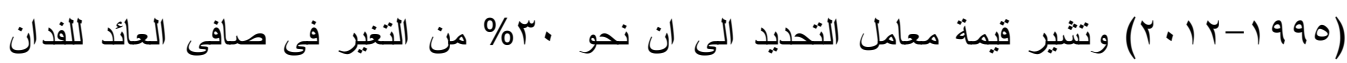

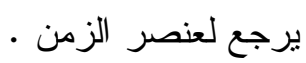

آراء المزارعين حول دور جمعيات الإصلاح الزراعى فى تسويق القطن من واقع دراسة ميدانية

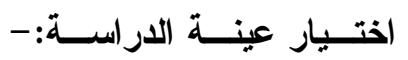

تهدف الدراسة موضع الاعتبار الى دراسة دور جمعيات الاصلاح الزراعى فى تسويق القطن

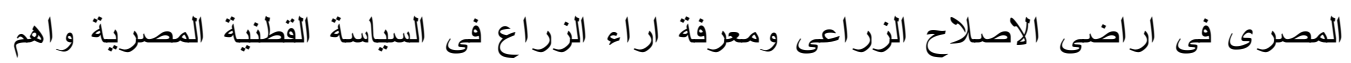
المشكلات التسويقية التى تواجههم ومدى كفاءة الجمعيات ، و دراسة الكفاءة التسويقية لمحصول

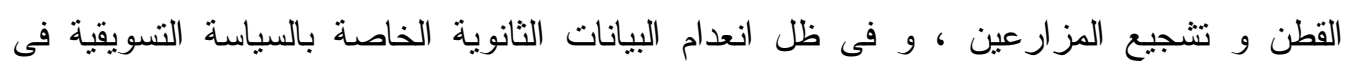

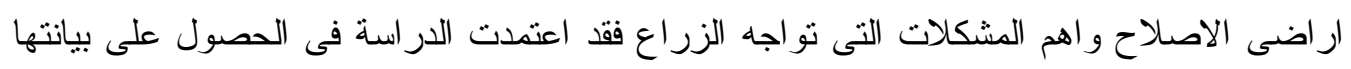

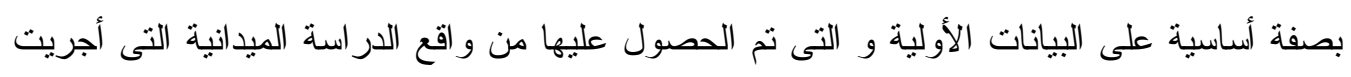
على عينة من المز ارعين بمحافظة البحيرة .

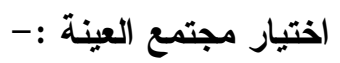

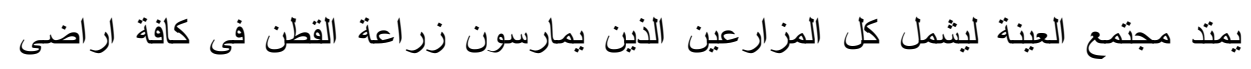

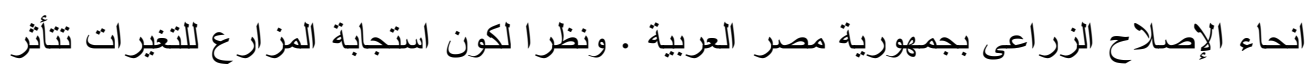

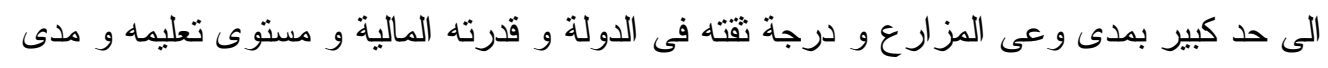

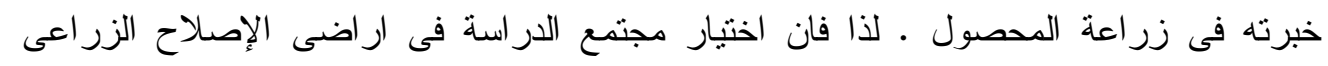

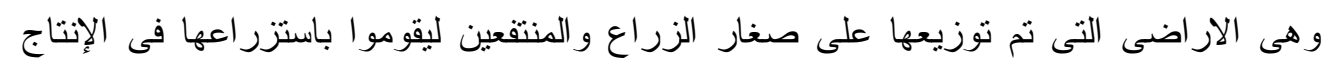

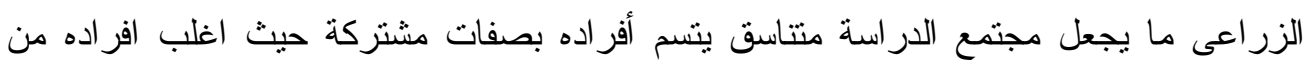
الفقر اء الاميين الذين بدأو الحياة العملية بخبرة طويلة و تمرسوا على مواجهة المشاكل الطارئة

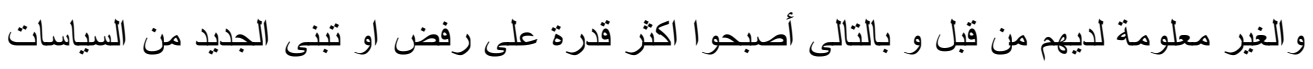


وفى ضوء تماتل محافظات الجمهورية من حيث انتشار مناطق الاصلاح الزر اعى فى كافة المحافظات لجميع القرى وفى ظل تمانل الصفات التى يتصف بها مزارعو اراضى اضى الاصلاح الزر اعى فقد اختيرت محافظة البحيرة كمجتمع للار اسة بطريقة عمدية حيث نأنى محافظة البحيرة

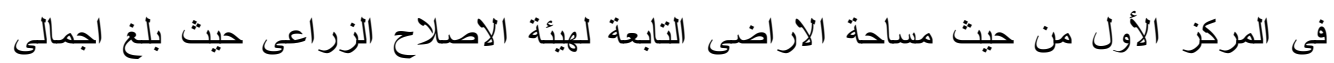

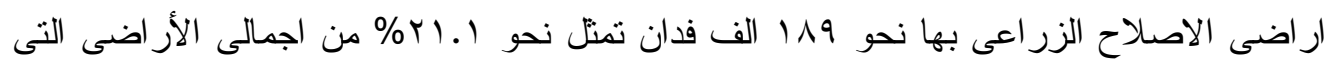

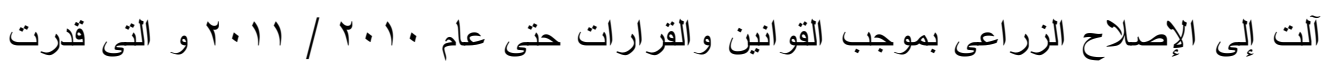
بنحو بوم الف فدان هذا بالاضافة الى ان محافظة البحيرة تحتوى على با الإنطقة و جمعيات

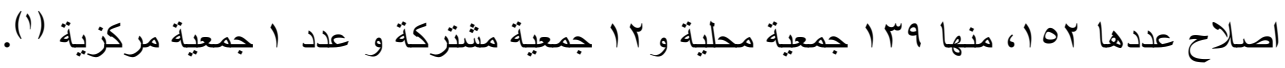
الهيكل التنظيمى لمديرية الاصلاح الزراعى بمحافظة البحيرة :

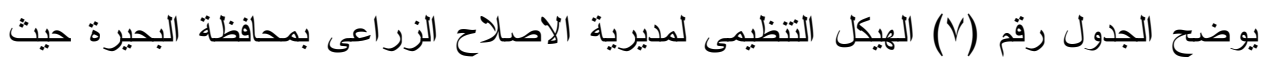

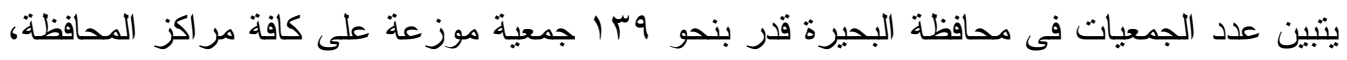

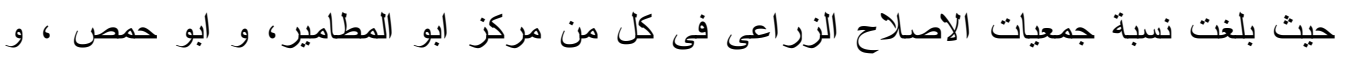
الخز ان اكثر من Vr\%\% من اجمالى عدد الجمعيات بالمحافظة ـ وقدر اجمالى عدد اعضاء مجلس

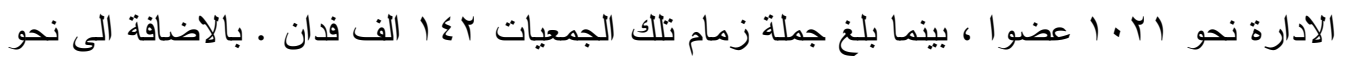
بr ا عضوا الجمعيات المشتركة، و اربعة عشر عضو ا فى الجمعيات المركزية بمحافظة البحيرة.

\begin{tabular}{|c|c|c|c|c|c|c|c|}
\hline \multirow{2}{*}{ ييلغ عدد } & 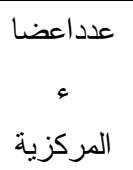 & عدداعضاء & عدل اعضساء & الجمعيات & جملة الزمام & المنطقة & s \\
\hline & \multirow{5}{*}{ يوجد } & 9 & VY & 9 & $\Lambda \wedge V 1$ & دمنهور & 1 \\
\hline الجمعية & & v & $\varepsilon r$ & v & A. vo & النوبارية & $r$ \\
\hline العامة & & 14 & 119 & 11 & $1 \leqslant 0 V A$ & ابو المطامير & $r$ \\
\hline \multirow{2}{*}{ للاصلاح } & & 9 & $0 \leqslant$ & 9 & $1 \cdot 1 \cdot v$ & الدلنجات & $\varepsilon$ \\
\hline & & ir & 117 & 11 & IVTII & ابوحصص & 0 \\
\hline من من & \multirow{2}{*}{ عضو ا فى } & $1 \pi$ & $|r|$ & 10 & $1+4 . V$ & كفر الدوار & 7 \\
\hline \multirow{6}{*}{ | البحيلاء } & & 9 & TV & 1. & $1 r \cdot 11$ & الابعادية & V \\
\hline & \multirow{3}{*}{ مركزية } & 0 & $r v$ & 0 & ritr & كوم حمادة & $\wedge$ \\
\hline & & $1 \pi$ & $1 \leq 7$ & 17 & $\mid V \leq V \varepsilon$ & الخزان & 9 \\
\hline & & 11 & $V \varepsilon$ & 11 & qVVV & ايتاى البارود & 1. \\
\hline & & 1. & $\mathrm{Vq}$ & 1. & $110 \mathrm{TV}$ & جبارس & 11 \\
\hline & & 11 & $1 . r$ & 11 & $107 \ldots$ & ادفينا & ir \\
\hline & & ITr & $1 \cdot r_{1}$ & 1149 & $1 \leq r 11 r$ & الاجمالى & \\
\hline
\end{tabular}

المصدر : جمعت وحسبت من:مديرية الاصلاح الزر اعى بالبحيرة ، و ادارة التعاون -الهيئة العامة للاصلاح الزر اعى عـ . ب . 


\section{الاهمية النسبية للجمعيات المحلية بمناطق الاصلاح الزراعى بالبحيرة :}

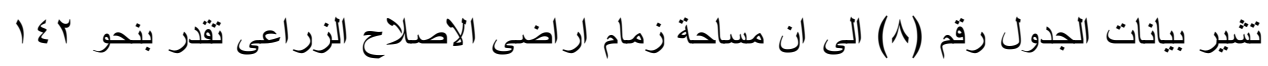

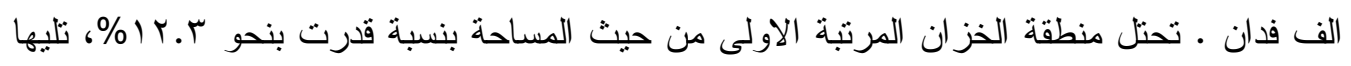

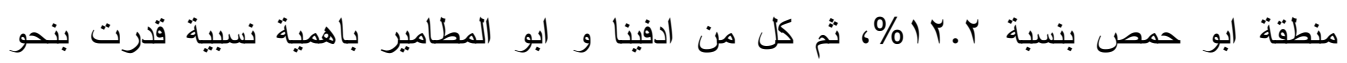

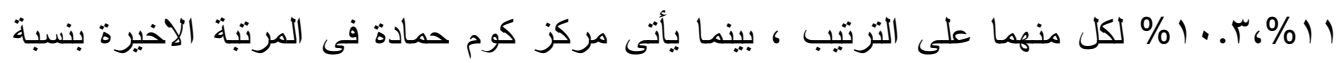

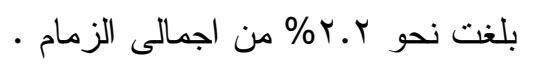

وبدراسة الاهمية النسبية لعدد الجمعيات فى مناطق الاصلاح بمام بحافظة البحيرة تبين من دراسة

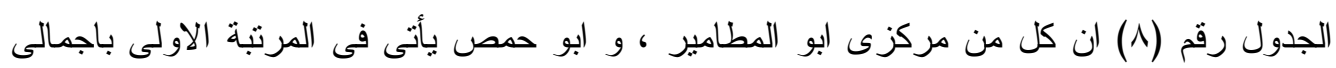

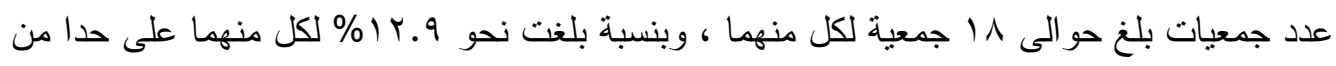

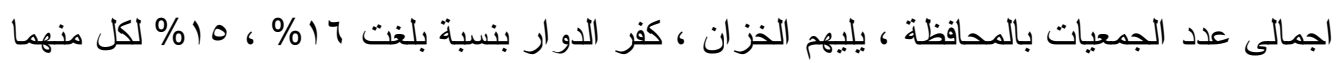

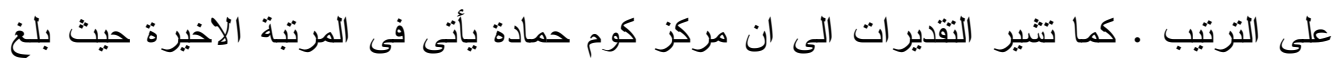

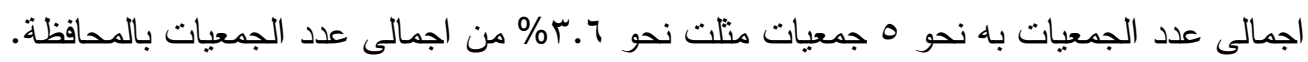

\begin{tabular}{|c|c|c|c|c|}
\hline الإهمية النسبية لعدد & الجمعيات & الاهمية النسبية لزمام & الزملة & المنطقة \\
\hline 7.0 & 9 & $7, Y$ & $\wedge \wedge \vee 1$ & دمنهور \\
\hline 0 & V & $0 . Y$ & 1. vo & النوبارية \\
\hline $1 r, 9$ & 11 & $1 \cdot, r$ & $1 \leqslant 0 V A$ & ابو المطامير \\
\hline 7.0 & 9 & $v, 1$ & $1 \cdot 1 \cdot v$ & الالنجات \\
\hline 17,9 & 11 & Ir, r & IVTII & ابو حمص \\
\hline $1 \cdot, 1$ & 10 & 9.7 & ITr.V & كفر الدوار \\
\hline$V, r$ & 1. & 1,0 & $1 Y \cdot 11$ & الابعادية \\
\hline$r .9$ & 0 & $r, r$ & TITV & كوم حمادة \\
\hline 11.0 & 17 & Ir, r & $\mid V \leqslant V \leqslant$ & الخز ان \\
\hline$V, q$ & 11 & 7.9 & $q \vee V V$ & ايتاى البارود \\
\hline$V, r$ & 1. & 1,1 & IIOYV & جبارس \\
\hline 8,9 & 11 & 11 & $107 \ldots$ & ادفينا \\
\hline $1 \cdots$ & 119 & $1 \cdots$ & $1 \leqslant r \| 1 /$ & الاجمالى \\
\hline
\end{tabular}

المصدر : جمعت وحسبت من : مديرية الاصلاح الزر اعى بالبحيرة ، بالهيئة العامة للاصلاح الزر اعى ع ا.ب . .

المرحلة الثانية من الاختيار هى اختيار منطقة الدراسة و نظر التزكز اراضى الاصلاح الزر اعى فى نحو r ا منطقة لذا تم ترتيب تلك المناطق من حيث حجم المساحة وتم ترتيبها وفقا للاهمية النسبية

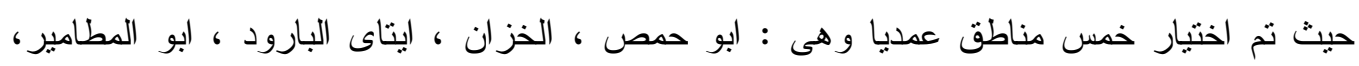

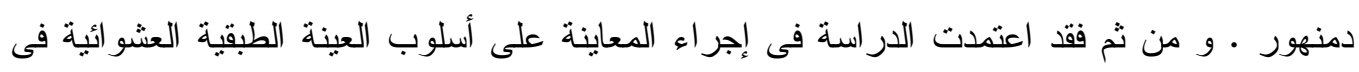

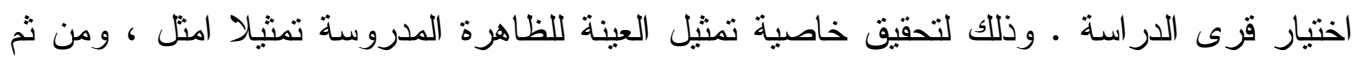
تضمن نطاق الدراسة 19 قرية وجمعية مركزية تقع ضمن المناطق الخمس السابقة .أما مرحلة الاختيار الأخيرة فقد تنتلت فى اختيار مفردات العبنة نفسها بطريقة عثو ائية بسبطة من قرى فرى الدراسة 
و قد تم حساب حجم العينة المختارة من كل منطقة باستخدام طريقة الوسط الهندسى المعدل

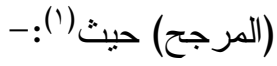

الوسط الهندسى = ل الأهمية النسبية لعدد الحائزين × الأهمية النسبية للمساحة الوسط الهنسى لكل قرية ...

جملة الوسط الهنسىى الوسط الهندسى المعدل = الوسط الهنسى المعدل × . 1. 1 $1 \ldots$ حجم العينة

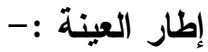

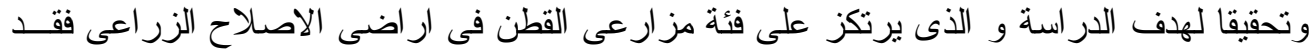

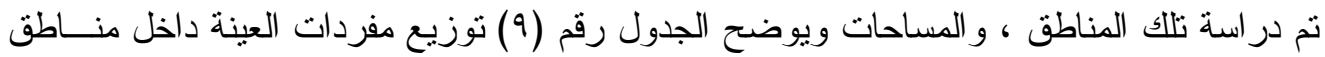

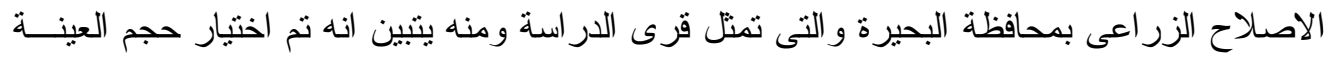

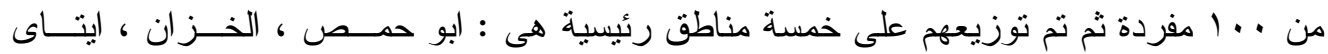

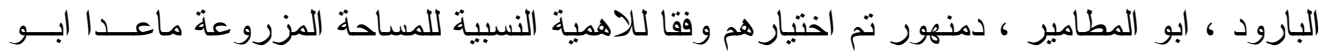
المطامير فقد وقع الاختيار عليها رغم صغر مساحتها لان كل المنطقة تزرع قطن فقط ـ. وقد اختير من الخمس مناطق عدد من القرى تم اختبار ها عشو ائيا كما بالجدول .

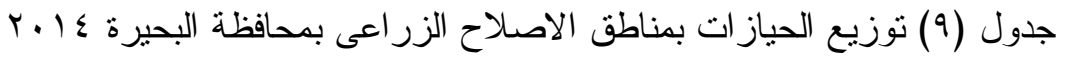

\begin{tabular}{|c|c|c|c|c|}
\hline حجم العينة & الوزن النسبى & بالقير اط & القرية & المنطقة \\
\hline$r$ & $r, \cdot \cdot$ & $r r$ & جمعية ابو حمص & \multirow{7}{*}{ ابو حمص } \\
\hline$r$ & r., & $\sum 7$ & الصالحية & \\
\hline$r$ & $r, \cdot \bullet$ & 01 & عبد الرازق & \\
\hline 1 & $1, \cdot \bullet$ & ro & ابو الخير & \\
\hline$r$ & $r, \cdot \bullet$ & 7. & الوكيل & \\
\hline$r$ & $r, \cdot \cdot$ & 00 & انور المفتى & \\
\hline$r$ & $r, \cdot \cdot$ & AT & نصر الله & \\
\hline$\xi$ & $\xi, \cdots$ & r10 & قرى تفتيش سندريتا & \multirow{6}{*}{ 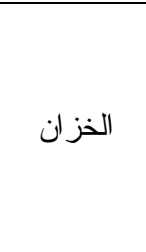 } \\
\hline$r$ & $r$ & $9 r$ & عزبة المكتب & \\
\hline 0 & $0, \cdots$ & §TT & فيشة & \\
\hline$\varepsilon$ & $\xi$ & IVI & عزبة العشرة & \\
\hline$r$ & $r$ & $\xi \Lambda$ & عزبة ليبيا & \\
\hline$r$ & $r$ & 71 & عزبة ستمائة & \\
\hline is & $1 \xi, \cdot \cdot$ & $\xi \xi \cdot$ & الاحمدية & ايتاى البارود \\
\hline ir & IY... & riv & جمعية عباس سيد احمد & ابو المطامير \\
\hline ir & $1 \mathrm{~T}, \cdot \cdot$ & rar & الصابرية & \multirow{5}{*}{ دمنهور } \\
\hline$\Lambda$ & $\Lambda$ & YIq & حوض المهندس & \\
\hline$r$ & $V, \cdot \bullet$ & 91 & زرقول & \\
\hline 0 & 0 & 119 & الخزان البحرى & \\
\hline$\wedge$ & $\Lambda$ & Y\&1 & حوض سلطان & \\
\hline $1 \cdots$ & $r r \cdot V$ & YYIS & جمار & \\
\hline
\end{tabular}

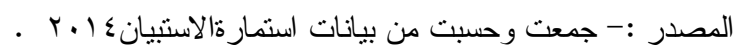

(1) William G.Cochran, Sampling Techniquse, Wiley EasternLimited, 1977. 
هذا و قد نم تجميع البيانات المتعلقة بالاستمارة من خلال المقابلة الثخصية التى قام بها الباحث بنفسه للتأكد من صحة و دقة البيانات المطلوبة للار اسة ، و و قد تم تجميع بيانات العينة فى الموسم

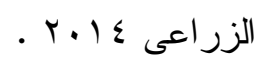

و يجدر الإشارة فى هذا الصدد إلى الصعوبات التى واجهت الباحث فى جمع البيانات و التى يتمثل بعضها فى :-اتساع منطقة البحث و تبعثر ها على مساحة جغر افية و اسعة فى ظل فل عدم وجود بيانات

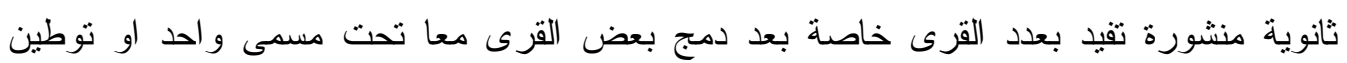

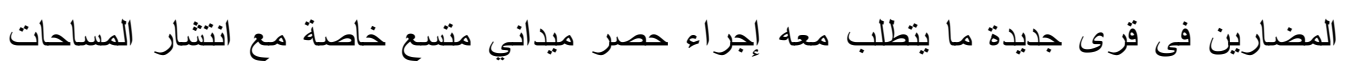

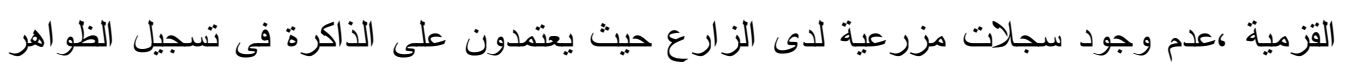

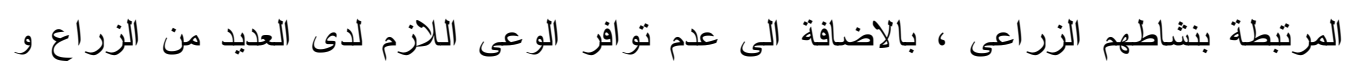
تخوفهم من الإجابة على الأسئلة ـ و قد روعى في الخى اختيار العينة مدى استجابة المبحوثين فى توفير

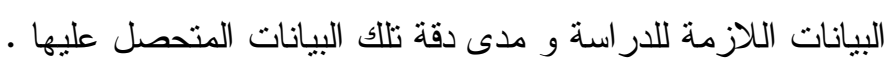

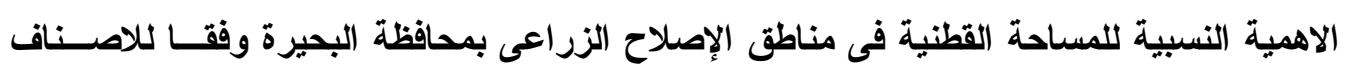
ومناطق الانتاج : يوضح الجدول رقم (• () الاهمية النسبية للمساحة القطنية فى اراضى الإصلاح حيث ينبين من

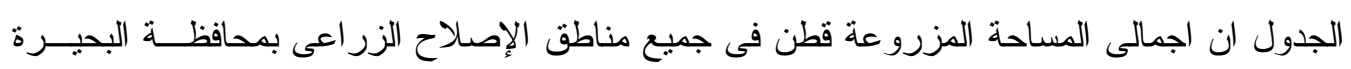

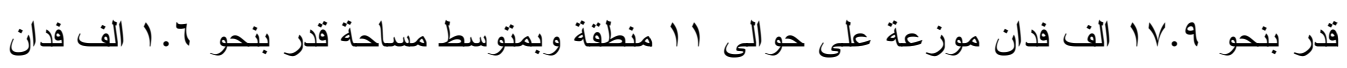

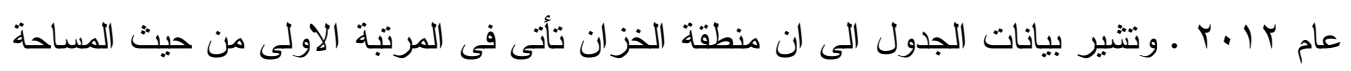

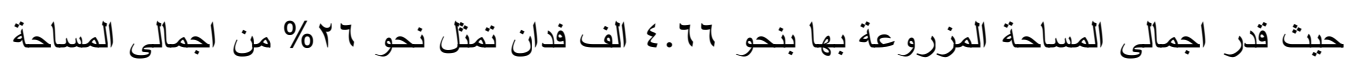

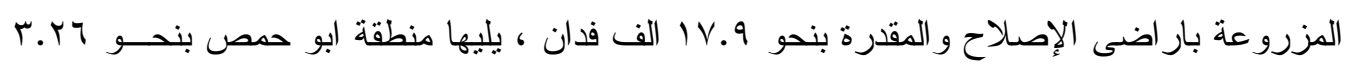

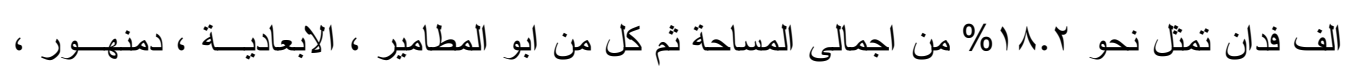

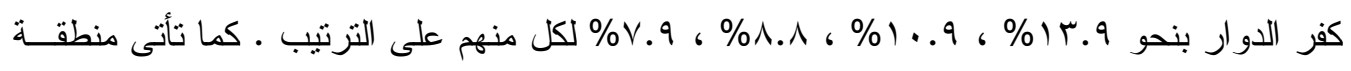

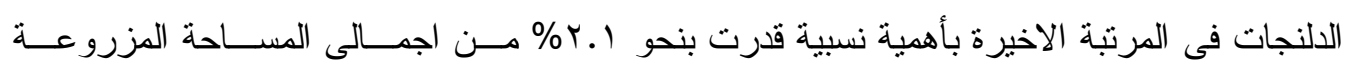
بار اضى الإصلاح الزر اعى .

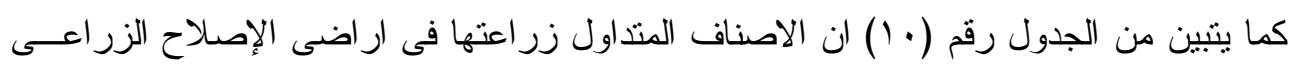

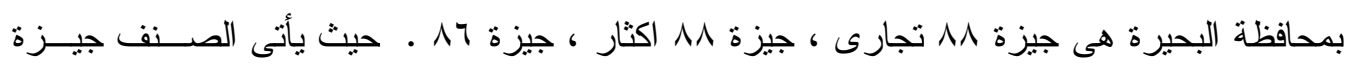

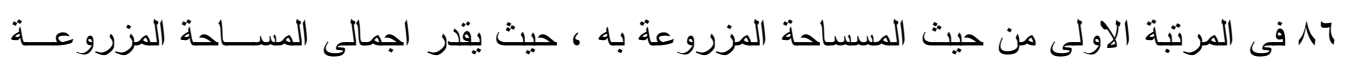

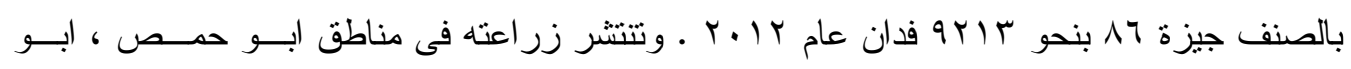

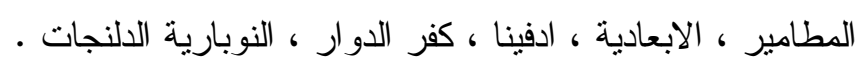

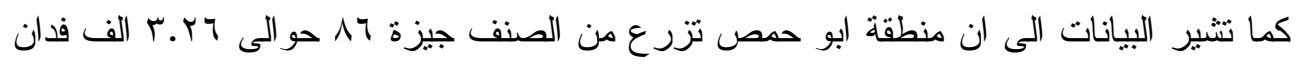

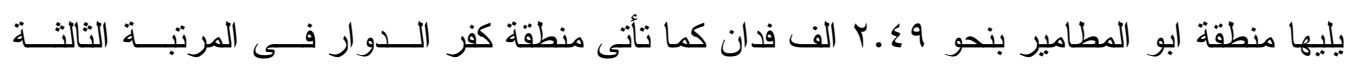

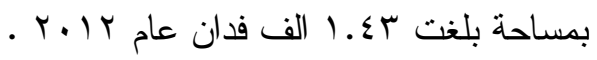


اما الصنف جيزة ^^ تجارى فيأتى فى المرتبة الثانية بمساحة بلغت حو الى 1 الاف فدان موزعــة

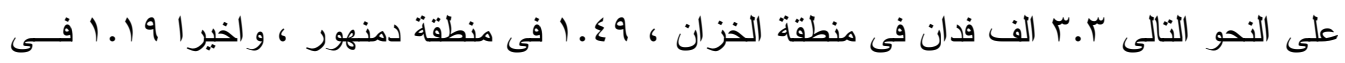

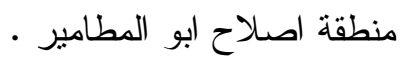
كما تثبر بيانات الجدول رقم (• () الى ان الصنف جيزة 11 اكثار يزرع في مناطق ايتاى

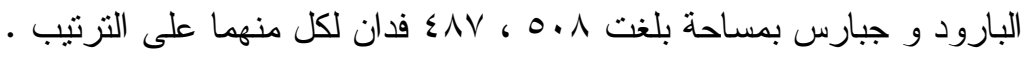

جدول رقم (• () تطور المساحة المزروعة من محصول القطن وفقا للاصناف بمناطق الإصلاح

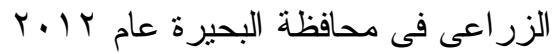

\begin{tabular}{|c|c|c|c|c|c|}
\hline \multicolumn{3}{|c|}{ الاصناف } & \multirow{2}{*}{ الاهمية النسبية } & \multirow{2}{*}{ المساحة } & \multirow[b]{2}{*}{ المنطقة } \\
\hline جيزة 11 & جيزة ^^ اكثار & جيزة ش & & & \\
\hline- & Ir\&. & . & rq & ร79. & الخزان \\
\hline . & - & - & MA.r & rry. & ابو حمص \\
\hline$r \leq 10$ & - & 1194 & $1 r, 9$ & r₹10 & ابو المطامير \\
\hline \multirow[t]{2}{*}{$\leq 7$. } & - & - & $1 \cdot, 9$ & 190. & الابعادية \\
\hline & - & 1ะ9. & $\Lambda, \Lambda$ & loAr & دمنهور \\
\hline $1 \leqslant Y 7$ & - & - & V.q & IEYY & كفر الدوار \\
\hline $71 \leq$ & - & - & r., & $71 \varepsilon$ & ادفينا \\
\hline $7 .$. & - & - & $r, r$ & $9 \cdot$. & النوبارية \\
\hline- & 0.1 & - & r.A & $0 \cdot 1$ & ايتاى البارود \\
\hline- & \&AV & - & r.Y & \&AV & جبارس \\
\hline rา & - & - & r.1 & $\mathrm{man}$ & الدلنجات \\
\hline qYIT & rVYO & $9 \cdots r$ & $1 .$. & IVas. & الاجمالى \\
\hline
\end{tabular}

المصدر : الادارة العامة للاصلاح الزراعى، مليرية البحيرة، قسم الانتاج الزراعى، بيانات غير منشورة.

\section{تطور الكميات المسوقة من القطن بمناطق الاصلاح الزراعى فى محافظة البحيرة تطور الكميات المسوقة}

يوضح الجدول رقم (1') الكميات المسوقة من محصول القطن فى مناطق الاصلاح الزر اعى بمحافظة البحيرة حيث تبين ان الكمية المسوقة قد اخذت فى التذبذب صعودا وهبوطا خلال الفترة

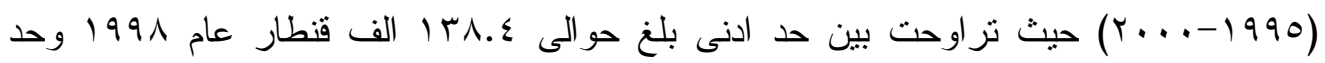

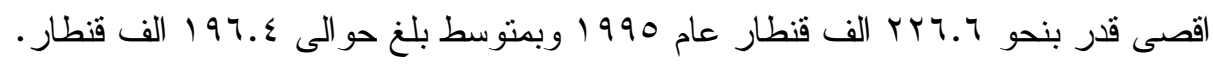

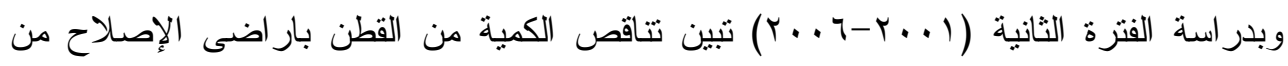
حو الى V.V

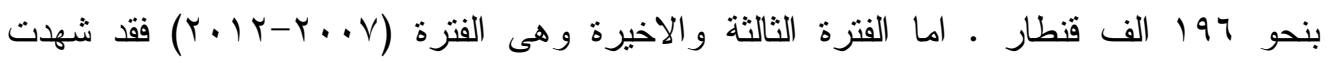
انخفاضا حاد فى الكميات المسوقة من القطن نظر التراجع الانتاج فى اراضى الإصلاح مقارنة ولنة

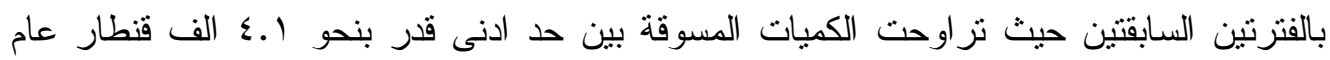

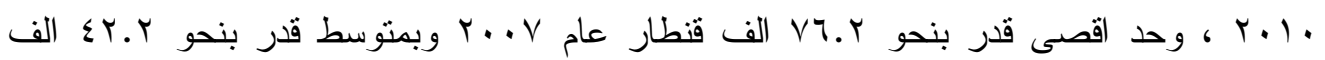


جدول رقم (1) تطور كمية وقيمة القطن المسوقة بمناطق الاصلاح الزر اعى فى محافظة البحيرة

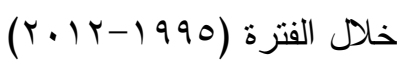

\begin{tabular}{|c|c|c|}
\hline بالمليون جنيه & الكمية المسوقة & السنو ات \\
\hline VO. $\leqslant Y$ & TrT.T & 1990 \\
\hline I. r.r & 179.17 & 1997 \\
\hline$M \cdot . \wedge$ & YA.V & 1998 \\
\hline $00 . \wedge r$ & IM. & 1991 \\
\hline$T V . \varepsilon \varepsilon$ & $191 . V 4$ & 1999 \\
\hline Aะ.।TV & rYY.l & r... \\
\hline AE.rT & 197.5. & متوسط الفترة \\
\hline VA. .7 & rVA.V & $r \cdot .1$ \\
\hline 1.4 .17 & rTO.r & r.Pr \\
\hline 94.7 & $17 \varepsilon .1$ & $r \cdot . r$ \\
\hline $170 . \mathrm{VT}$ & r7r.q & r..६ \\
\hline $1 \leqslant 1.1$ & $1 \leqslant \Lambda$ & $r \cdot .0$ \\
\hline rז.Tr & 1..० & 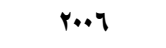 \\
\hline $1.1 .9 r$ & $197 . . V$ & منتسط الفترة \\
\hline $0 \wedge .7 \mathrm{~V}$ & VT.Y & $r \cdots r$ \\
\hline rV.TE & $\sum V .0 Y$ & $r \cdots 1$ \\
\hline$r .70$ & $\varepsilon . \varepsilon$ & $r \ldots q$ \\
\hline $1 . .7$ & 5.10 & r.1. \\
\hline$v 1.0$ & TY.V & $r+11$ \\
\hline$T \varepsilon . T$ & ON.r & $r \cdot 1 r$ \\
\hline$\varepsilon . .97$ & $\sum Y . Y 1$ & منوسط الفترة \\
\hline
\end{tabular}

المصدر : جمعت و حسبت من الادارة العامة للمعلومات و التوثيق،الهيئة العامة للاصلاح الزر اعى، بيانات غير منشورة، ع ا.ب. وبمقارنة متوسطات الفترات الثلاث ينبين نراجع الكمبات المسوقة من حوالى ؛. 197 الف أف قنطار كمتوسط للفترة الاولى وهى الفترة التى اعقبت تطبيق سياسات التحرر الاقتصادى لمحصول القطن الى نحو r.r الف قنطار وهى الفترة الاخيرة مما يظهر مدى التذهور الذى لحق بمحصول • القطن

ويوضح الجدول رقم (Y I) معادلة الاتجاه الزمنى العام للكمية المسوقة من محصول القطن فى القى

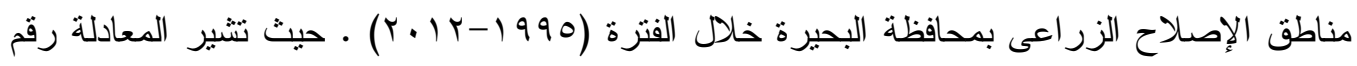

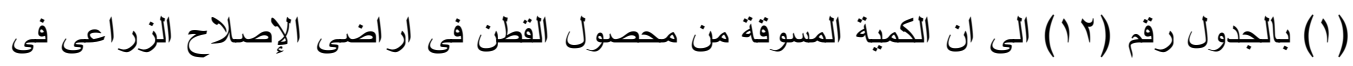

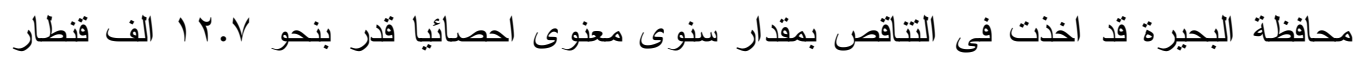

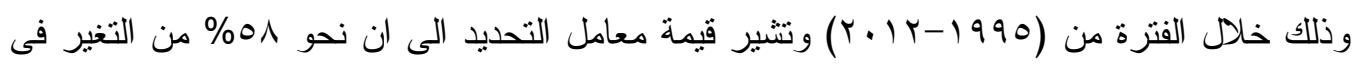

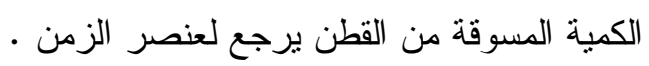


جدول رقم (Y ( ) معادلات الاتجاه الزمنى العام لكمية وقيمة القطن المسوق

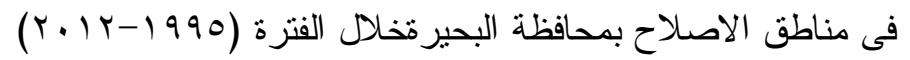

\begin{tabular}{|c|c|c|c|c|}
\hline $\mathrm{F}$ & $\mathrm{R}^{2}$ & 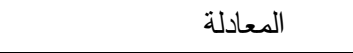 & البيـــــــــــان & b \\
\hline rt &. .01 & $Y=r 70-1 Y . V X$ & \multirow{2}{*}{ الكمية المسوقة بالالف قنطار } & \multirow{2}{*}{1} \\
\hline & & $(-\varepsilon . \nu)^{* *}$ & & \\
\hline$r$ & $.1 \wedge$ & $Y=1 . V-r . . . \leq X$ & \multirow{2}{*}{ قيمة القطن المسوق بالالف جنيه } & \multirow{2}{*}{ r } \\
\hline & & $(-1 . \wedge) * *$ & & \\
\hline
\end{tabular}

المصدر : جمعت و حسبت من الجدول رقم (1) بالدر اسة

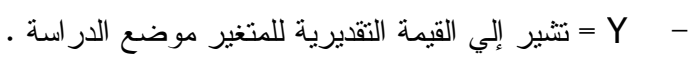

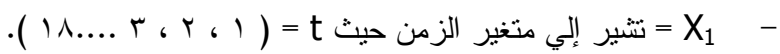

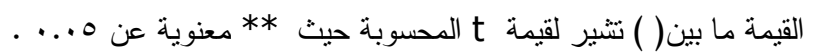

تطور قيمة الكميات المسوقة من القطن فى مناطق الاصلاح الزراعى بمحافظة البحيرة

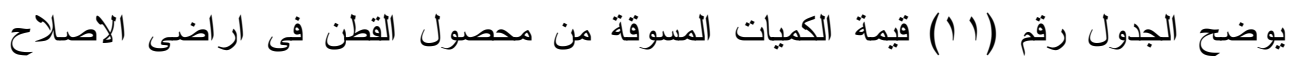
الزر اعى فى محافظة البحيرة تبين ان قيم الكية المسوقة قد اخذت فى التذبذب صعودا وهبوطا خلال

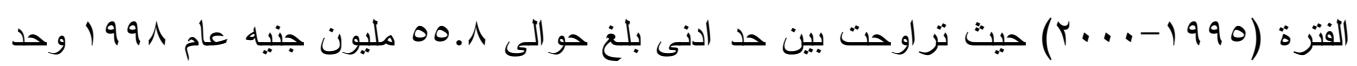

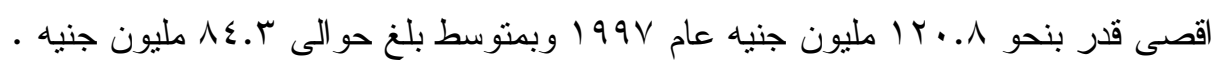

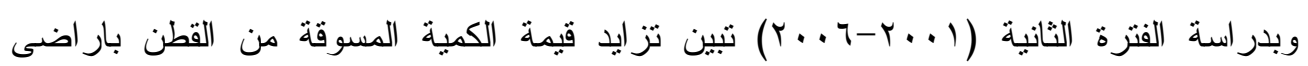

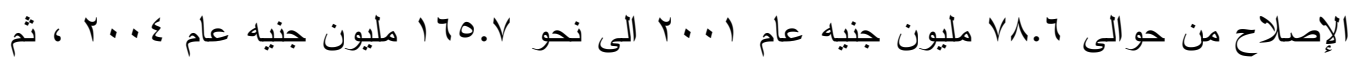

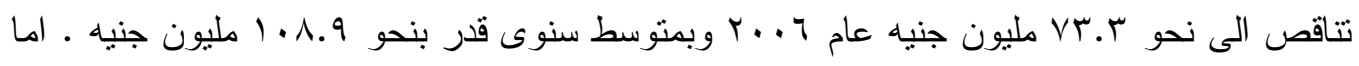

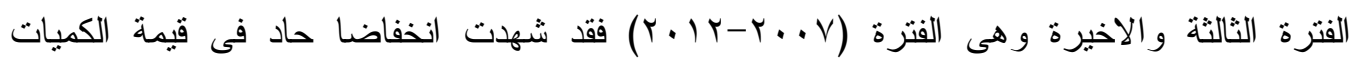
المسوقة من القطن نظر التراجع الانتاج فى اراضى الإصلاح مقارنة بالفتزتين السابقتين حيث

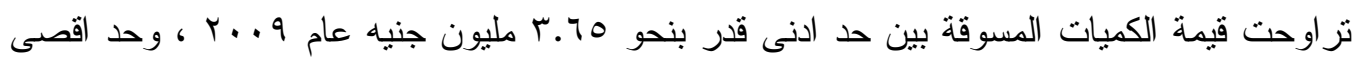

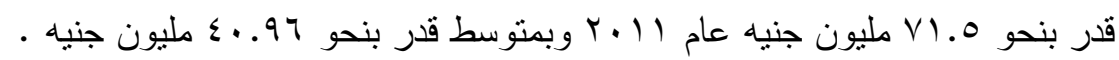
وبمقارنة منوسطات الفترات الثلاث ينتين نز ايد متوسط قيمة الكميات المسوقة من القطن خلال

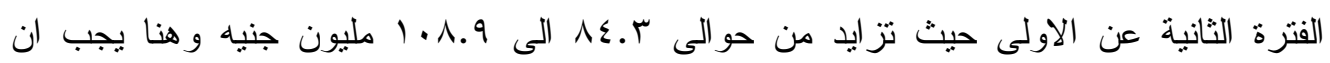

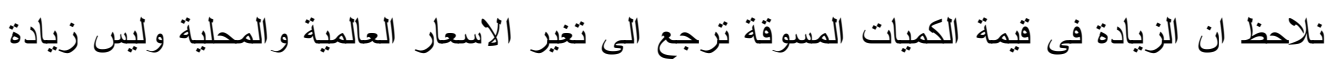

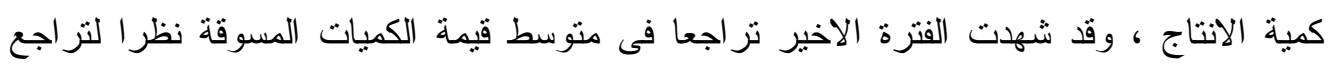

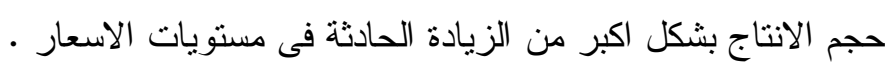

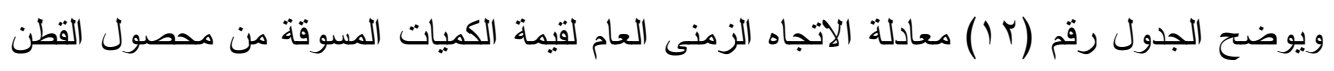

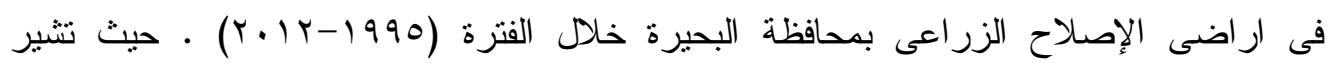

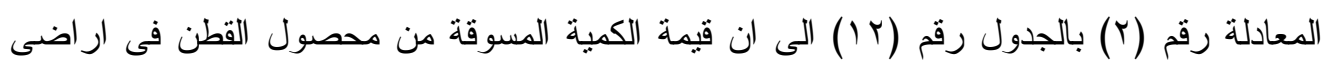

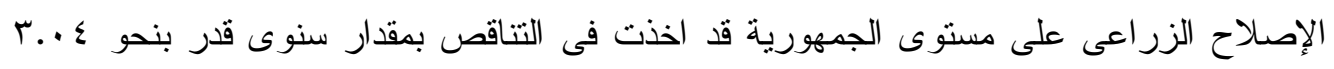

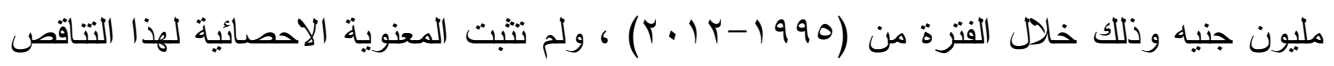
مما يعنى ان القيم تدور حول منوسطاتها مدرن 


\section{خصائص مجتمع الاراسة خصائص مزارعى العينة}

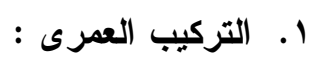

يوضح الجدول رقم ( با) التركيب العمرى لمفردات العينة بمناطق الدراسة حيث تبــين مــن

- منطقة (بو حمص : تبين من الجدول ان عينة الدراسة بمنطقة ابو حمص قد خلت من الفئـة

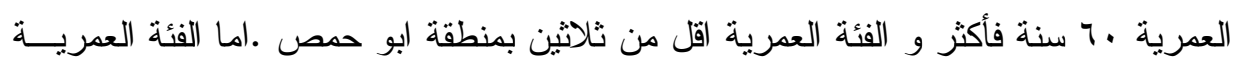

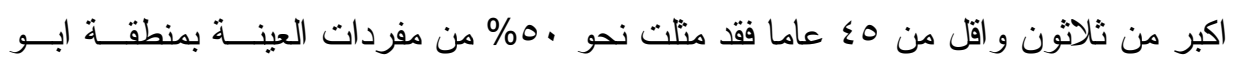

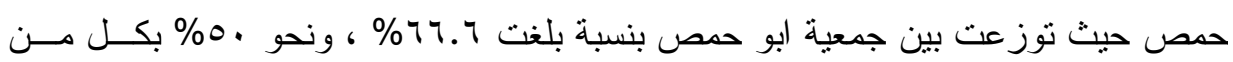

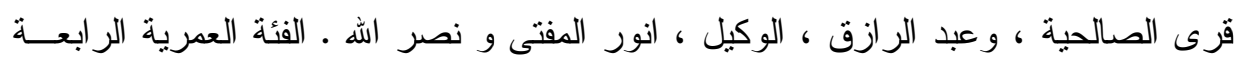

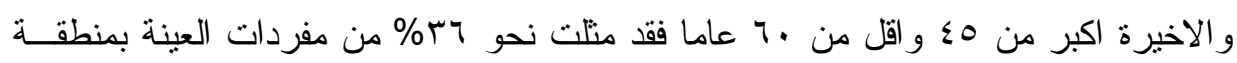

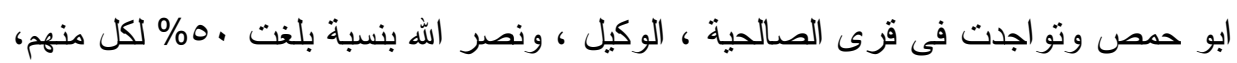

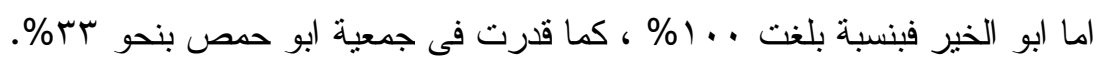

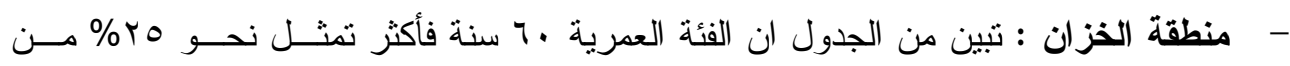

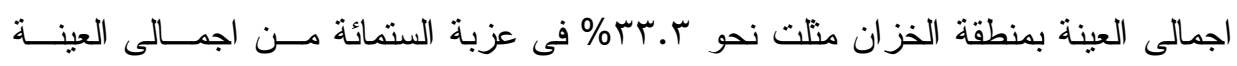

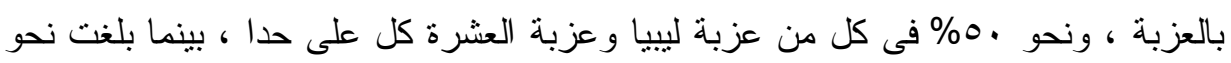

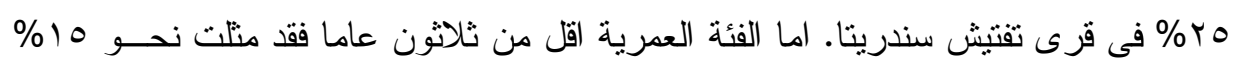

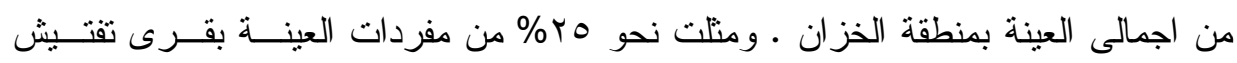

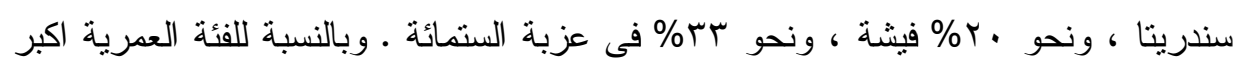

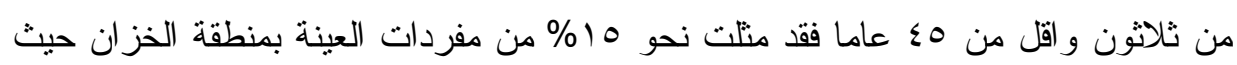

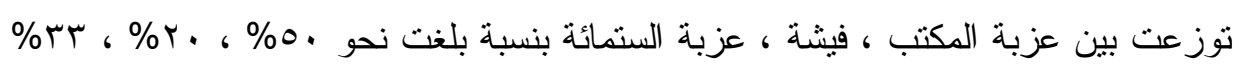

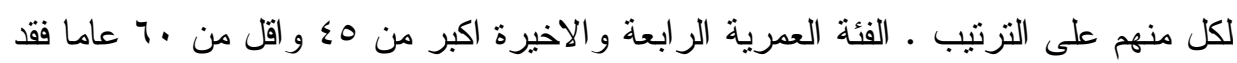

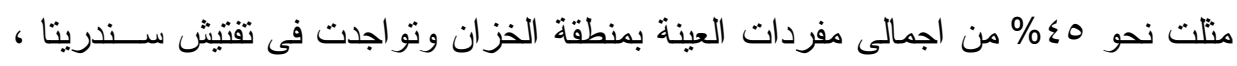

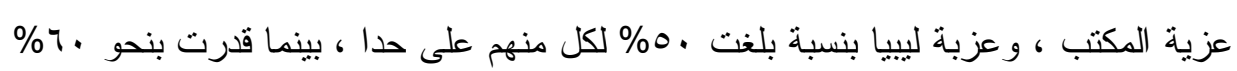
في عزبة فيشة. - - منطقة ايتاى البارود : يوضح الجدول رقم (T ( ) توزيع مفردات العينة على مختلف الفئـات

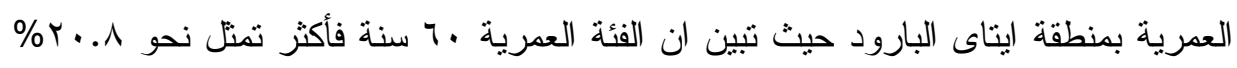

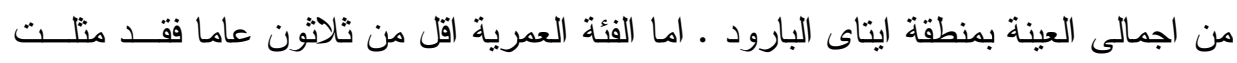

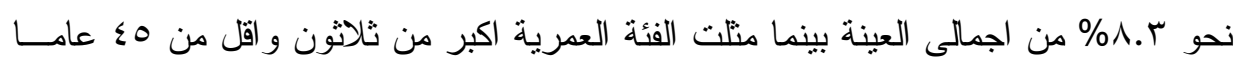

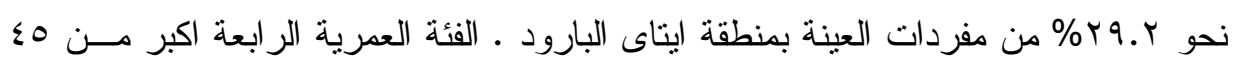

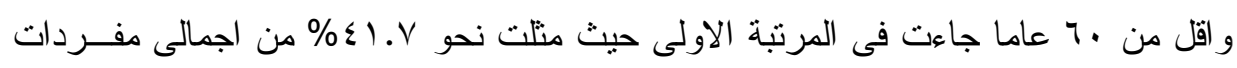
العينة بمنطقة ايتاى البارود. 


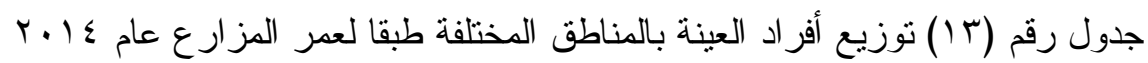

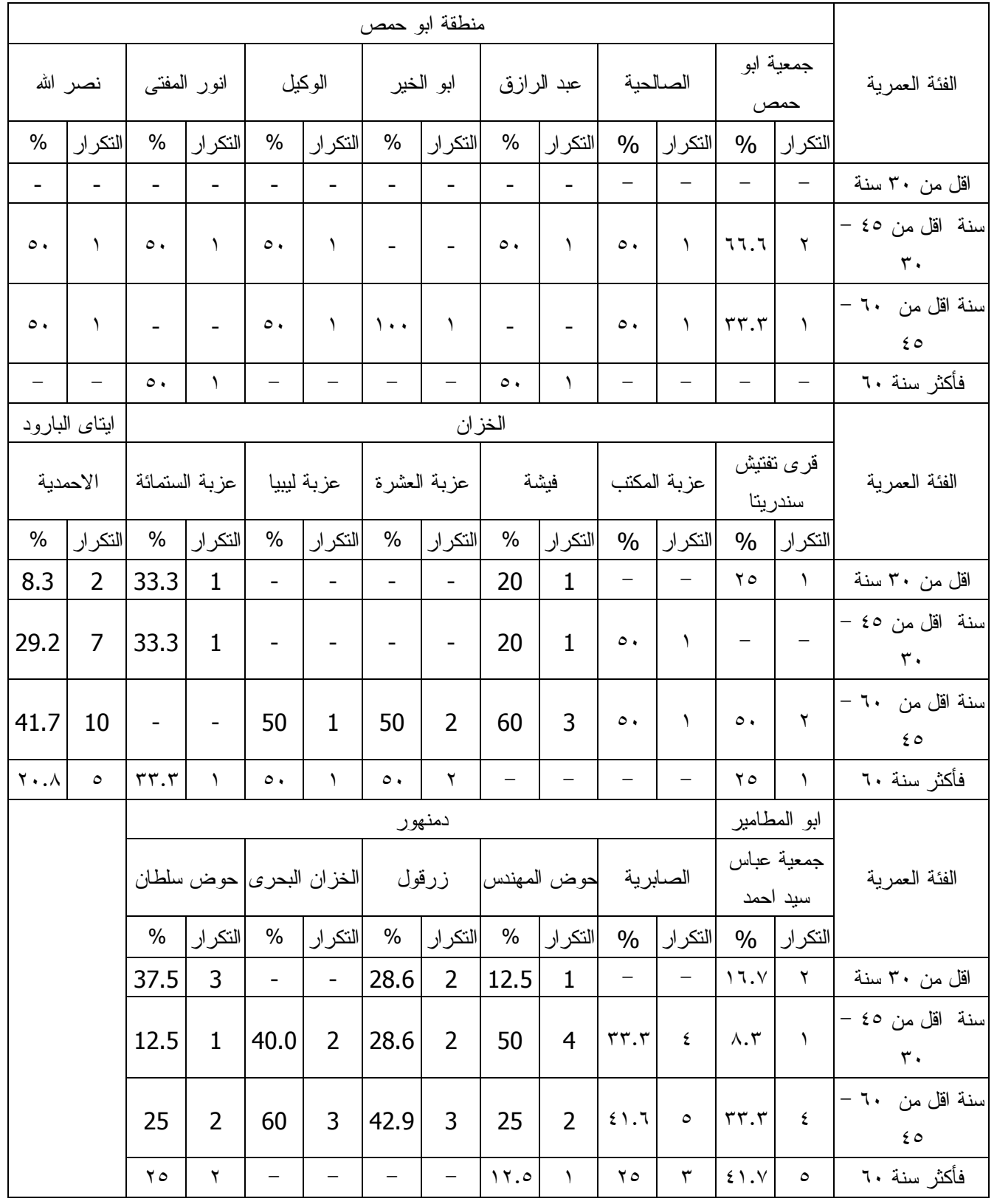

المصدر :- جمعت و حسبت من بيانات استمارة الاسنييان الخاصة بالدر اسة .

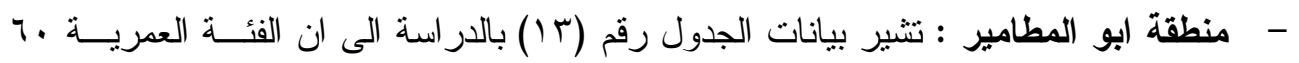

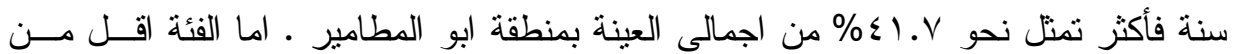

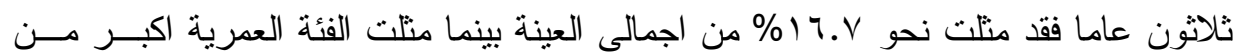

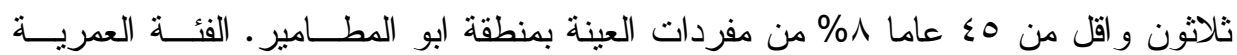

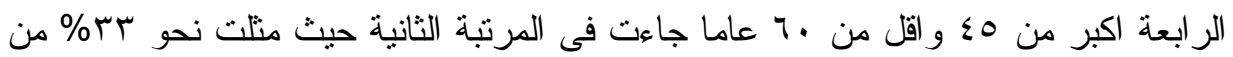

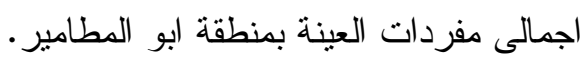

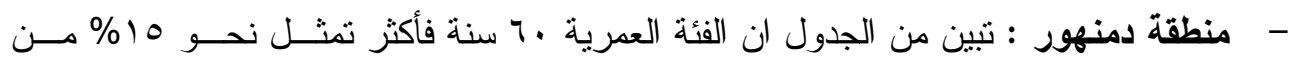

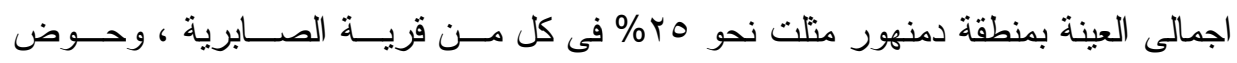




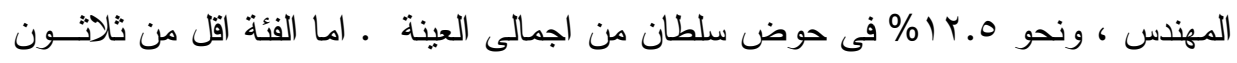

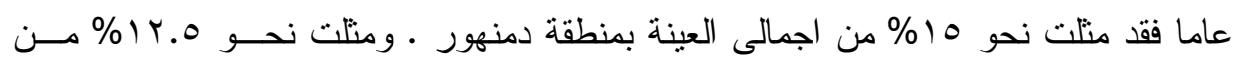

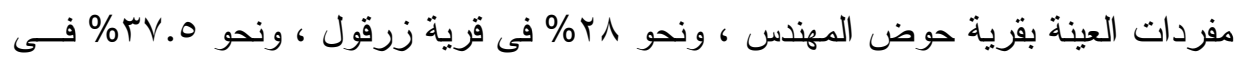

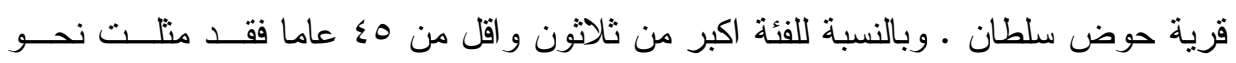

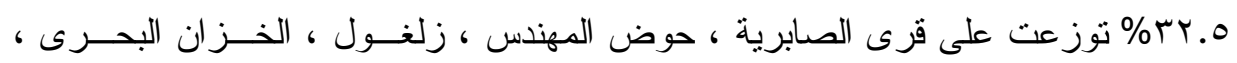

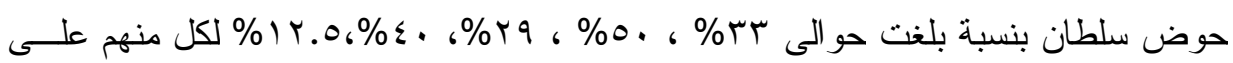

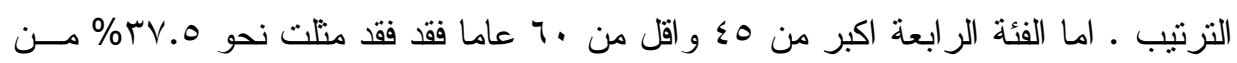

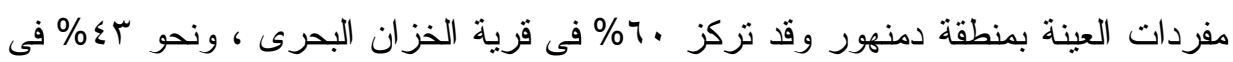

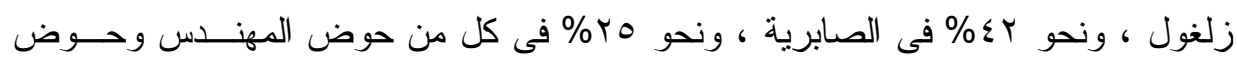

\section{r- توزيع العينة وفقا للفئة الحيازية للمزارع :}

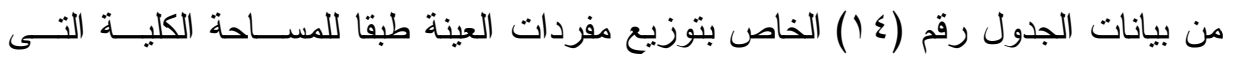

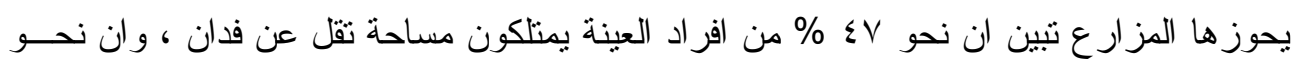

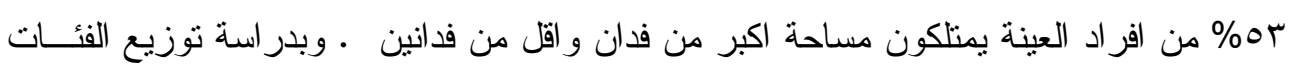

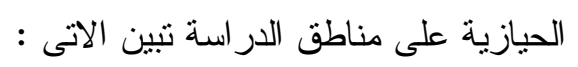

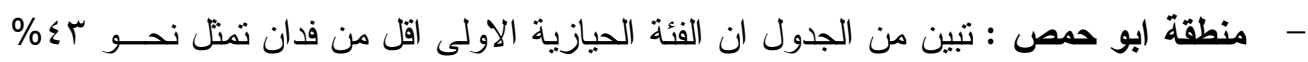

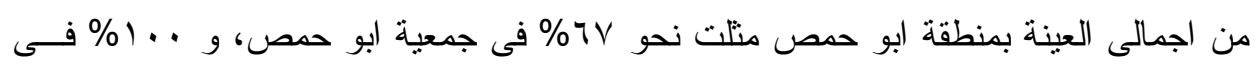

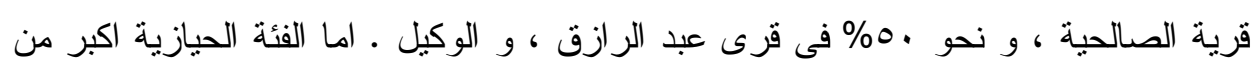

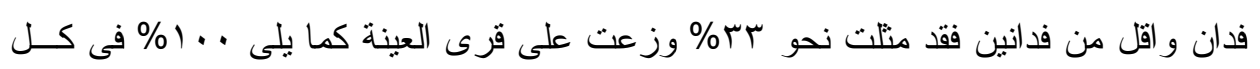

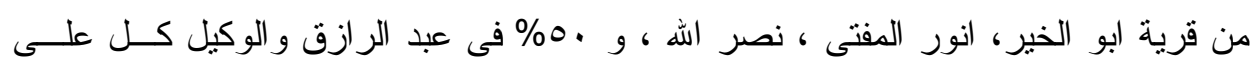
حدا. - منطقة الخزان : تنين من الجدول ان الفئة الحيازية اقل من فدان بمنطقة الخزان قد منلت نحو

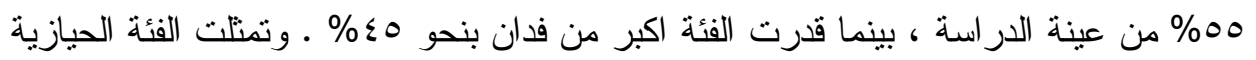

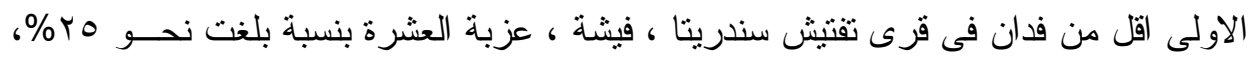

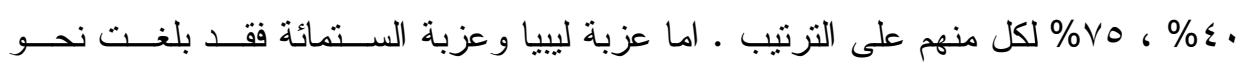

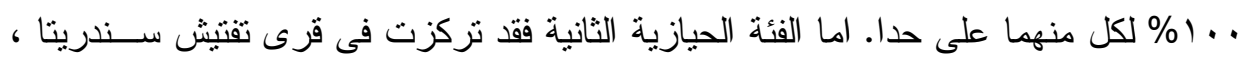

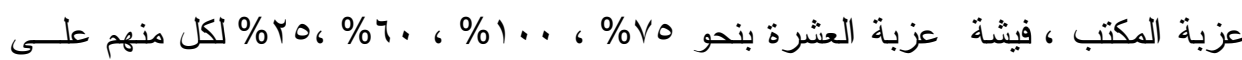




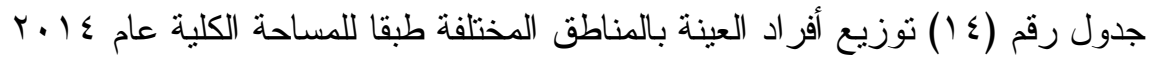

\begin{tabular}{|c|c|c|c|c|c|c|c|c|c|c|c|c|c|c|}
\hline \multicolumn{14}{|c|}{ منطقة ابو حمص } & \multirow{3}{*}{ الفئة الحيازية } \\
\hline \multicolumn{2}{|c|}{ نصر اله } & \multicolumn{2}{|c|}{ انور المفتى } & \multicolumn{2}{|c|}{ الوكيل } & \multicolumn{2}{|c|}{ ابو الخير } & \multicolumn{2}{|c|}{ عبد الرازق } & \multicolumn{2}{|c|}{ الصالحية } & \multicolumn{2}{|c|}{ جمعية ابو } & \\
\hline$\%$ & التكر ار & $\%$ & التكر ار & $\%$ & التكرار & $\%$ & التكر ار & $\%$ & | التكر ار & $\%$ & |التكر ار | & $\%$ & |التكر ار | & \\
\hline- & - & - & - & 0. & 1 & - & - & 50 & 1 & $\ldots$ & $r$ & 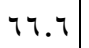 & r & |قل من فدان \\
\hline 100 & 2 & 100 & 2 & 0. & 1 & 100 & 1 & 50 & 1 & - & - & |r.T & 1 & |قل مدان \\
\hline \multicolumn{2}{|c|}{ ايتاى البارود } & \multicolumn{12}{|c|}{ الخزان } & \\
\hline \multicolumn{2}{|c|}{ الاحمدية } & \multicolumn{2}{|c|}{ عزبة الستمائة } & \multicolumn{2}{|c|}{ عزبة ليبيا } & \multicolumn{2}{|c|}{ عزبة العشرة } & \multicolumn{2}{|c|}{ فيشة } & \multicolumn{2}{|c|}{ عزبة المكتب } & \multicolumn{2}{|c|}{ قرى تفنتش } & \multirow[t]{2}{*}{ الفئة الحيازية } \\
\hline$\%$ & التكر ار & $\%$ & التكر ار & $\%$ & التكرار & $\%$ & التكر ار & $\%$ & |التكر ار & $\%$ & |التكر ار | & $\%$ & |التكر ار | & \\
\hline ro.v & 5 & 100 & 3 & 100 & 2 & 75 & 3 & 40 & 2 & - & - & ro & 1 & |قل من فدان \\
\hline \multirow[t]{6}{*}{$T$ TE.T } & 9 & - & - & - & - & ro & 1 & 7. & $r$ & $1 \ldots$ & r & vo & $r$ & |قل من بان \\
\hline & & \multicolumn{10}{|c|}{ دنهور } & \multicolumn{2}{|c|}{ ابو المطامير } & \multirow{3}{*}{ الفئة الحيازية } \\
\hline & & \multicolumn{2}{|c|}{ حوض سلطان | } & \multicolumn{2}{|c|}{ البحرى الخ } & \multicolumn{2}{|c|}{ زرقول } & \multicolumn{2}{|c|}{ الموضس } & \multicolumn{2}{|c|}{ الصابرية } & \multicolumn{2}{|c|}{ جمعيدة عباس احمد } & \\
\hline & & $\%$ & التكر ار & $\%$ & التكرار & $\%$ & التكر ار & $\%$ & |التكر ار & $\%$ & |التكر ار | & $\%$ & |التكر ار & \\
\hline & & $5 v$ & 4 & 80 & 4 & 85.7 & 6 & 37.5 & 3 & $\sum 7 . Y$ & 7 & 17.8 & $r$ & |قل من فدان \\
\hline & & $\varepsilon r$ & $r$ & $r \ldots$ & 1 & $1 \leq . r$ & 1 & Tr.O & 。 & $01 . \Gamma$ & V & הז.r. & 1. & |قل من ان \\
\hline
\end{tabular}

المصدر :- جمعت و حسبث من بيانات استمارة الاسنبيان الخاصة بالدر اسة .

- - منطقة ايتاى البارود : يتبين من الجدول رقم (ع () توزيع مفردات العينة على الفئات الحيازية بمنطقة ايتاى البارود حيث تبين ان الفئة الحيازية اقل من فدان تمثل نحو بـ\% من اجمــالى

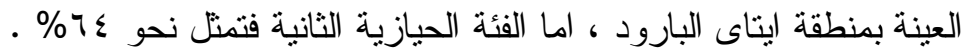
- - منطقة ابو المطامير : تثشير بيانات الجدول رقم (ع () بالدر اسة الى توزيع مفــردات العينـــة على الفئات الحيازية بمنطقة ابو المطامير حيث تبين ان الفئة الحيازية اقل من فدان تمنل نحو

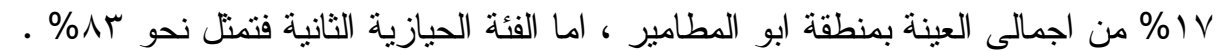

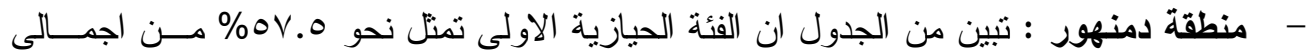

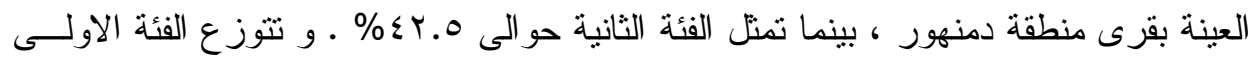

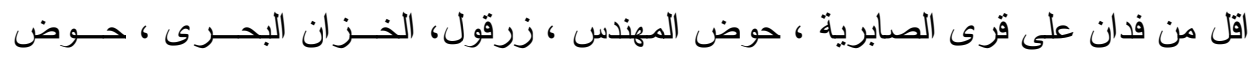

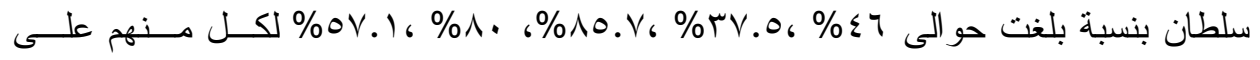
التزتيب • بينما تتوزع المساحة اكبر من فدان و اقل من فدانين فى جميع قرى منطقة الدر اســـة

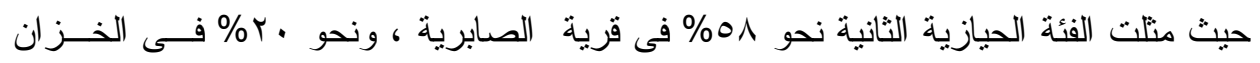

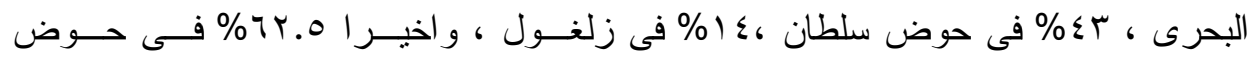




\section{ب- توزيع العينة وفقا للمهنة الأساسية :}

أوضحت نتائج الجدول رقم (10) ان نسبة من يمتهنون الزر اعة كمهنة أساسية قد مثلت نحو

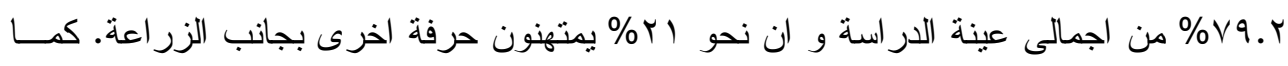

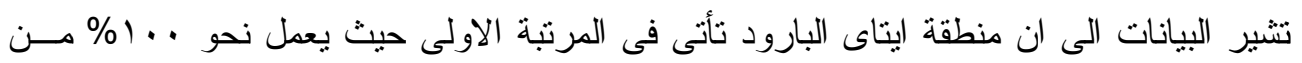

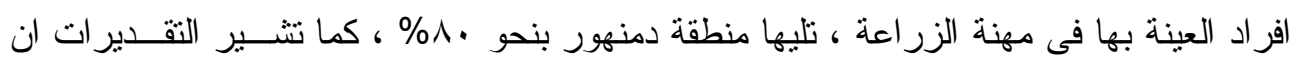

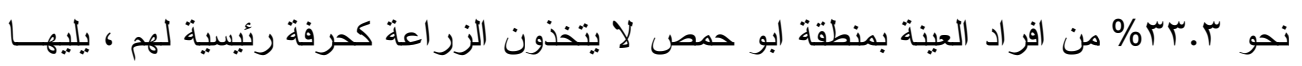

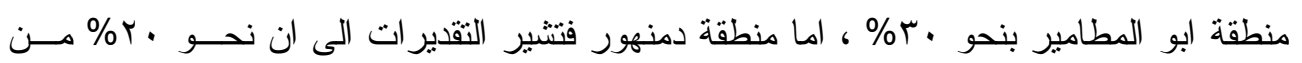
افر اد العينة يمتهنون الزر اعة كمهنة ثانوية. جدول رقم (10) توزيع أفر اد العينة بالمناطق المختلفة طبقا للمهنة الأساسية

\begin{tabular}{|c|c|c|c|c|c|c|c|c|c|c|}
\hline \multicolumn{10}{|c|}{ المناطق } & \multirow{3}{*}{ الأساسية } \\
\hline \multicolumn{2}{|c|}{ دمنهور } & \multicolumn{2}{|c|}{ ابو المطامير } & \multicolumn{2}{|c|}{ ايتاى البارود } & \multicolumn{2}{|c|}{ الخز ان } & \multicolumn{2}{|c|}{ ابو حمص } & \\
\hline$\%$ & التكر ار & $\%$ & التكر ار & $\%$ & التكر ار & $\%$ & التكر ار & $\%$ & التكر ار & \\
\hline NT.O & זr & $1 \ldots$ & Ir & VA.T & 11 & 75 & 1 & V). & 1. & نعم \\
\hline $1 v .0$ & 7 & - & - & Y.. & r & 25 & 0 & YA.T & $\varepsilon$ & $y$ \\
\hline
\end{tabular}

المصدر : جمعت وحسبت من استمارة الاستبيان

\section{تحليل اراء و توجهات المزارعين حول اهم المشكلات التسويقية التى تواجههم}

يو اجه البنيان الزر اعى المصرى مجموعة من المشاكل التى من شأنها أن تعوف العملية الإنتاجية

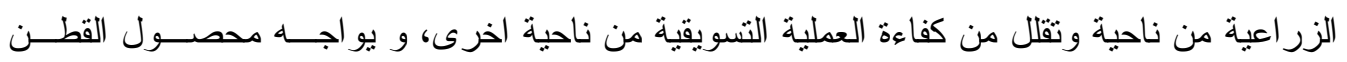

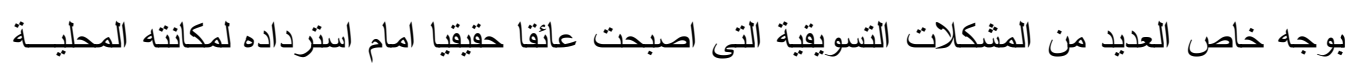
و الدولية فتبيان الاسعار بين الجهات التسويقية المختلفة ( حلقات تسويقية - تعاونيات- قطاع خــاص)

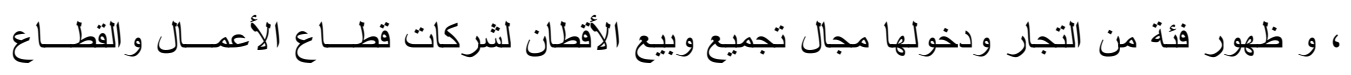

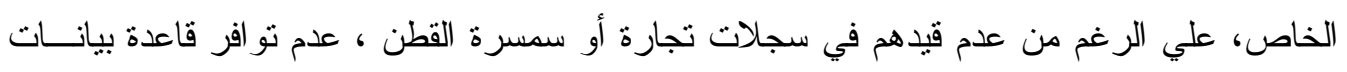

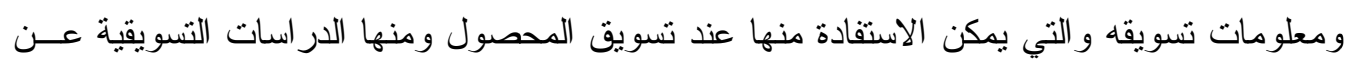

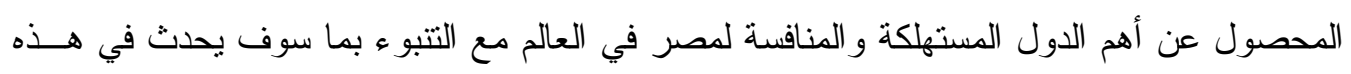

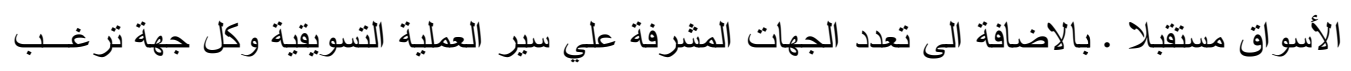

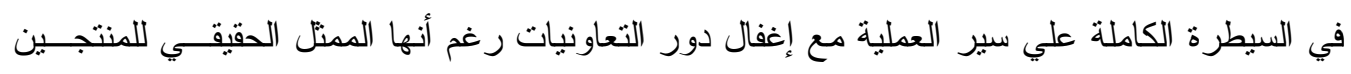

كلها امور دفعت بالمحصول الاقتصادى الاول الى الانسحاب من الخريطة الاقتصادية الزر اعية .

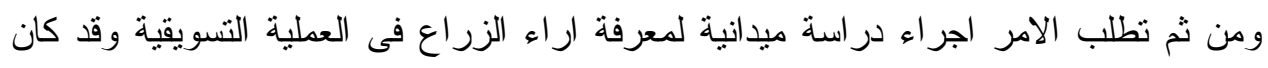

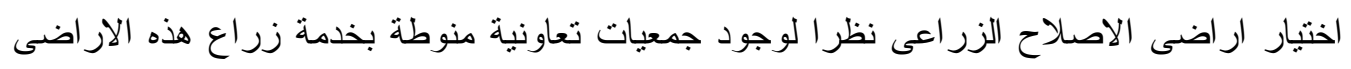

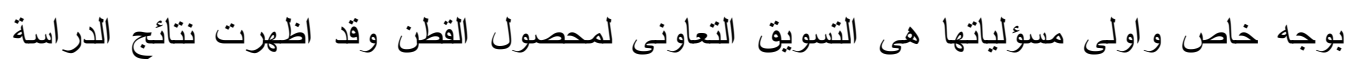

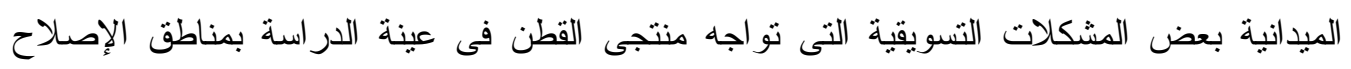

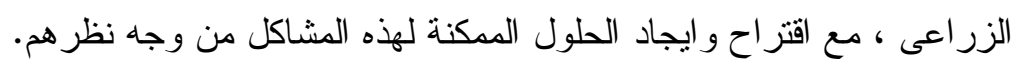




\section{آراء مزارعى العينة نحو عدم تناسب السعر المزرعى مع تكاليف الإتتاج}

يوضح الجدول رقم (7 (1) اتجاهات مزارعى العينة نحو السعر المزرعى لقنطار القطن حيث

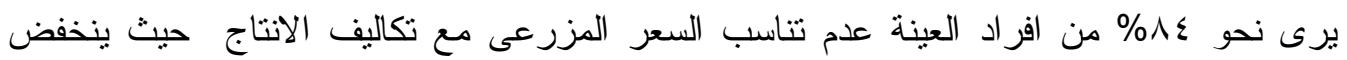
السعر المزرعى لقنطار القطن مقارنة بتكاليف الانتاج خاصة مع تقزم المساحات وتفتت الحيازة .

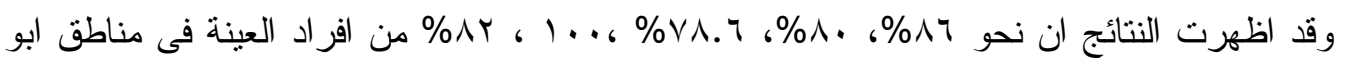

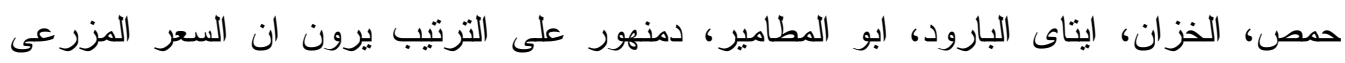

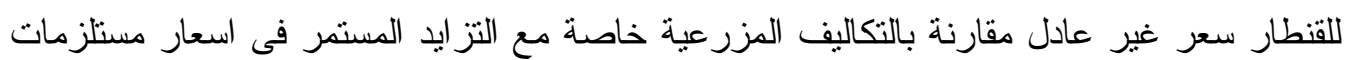
· الانتاج

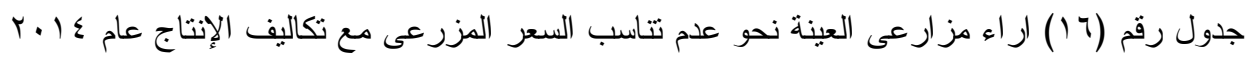

\begin{tabular}{|c|c|c|c|c|c|c|c|c|c|c|}
\hline \multicolumn{2}{|c|}{ دمنهور } & \multicolumn{2}{|c|}{ ابو المطامير } & \multicolumn{2}{|c|}{ ايتاى البارود } & \multicolumn{2}{|c|}{ الخز ان } & \multicolumn{2}{|c|}{ ابو حص } & \multirow{2}{*}{ البيان } \\
\hline$\%$ & التكر ار & $\%$ & التكر ار & $\%$ & التكر ار & $\%$ & التكر ار & $\%$ & التكر ار & \\
\hline Ar,O & rזr & 1.0 & ir & VA, 7 & 11 & A. & 17 & $\Lambda T$ & ir & نعم \\
\hline 17.0 & $\checkmark$ & - & - & MI, & $r$ & $r$. & $\varepsilon$ & $1 \varepsilon$ & r & y \\
\hline
\end{tabular}

المصدر :- جمعت و حسبت من بيانات استمارة الاستبيان

آراء مزارعى العينة نحو تأخير صرف المستحقات المالية وعدم صرف قيمة المحصول دفعة واحدة المان

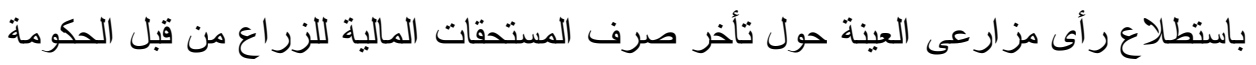

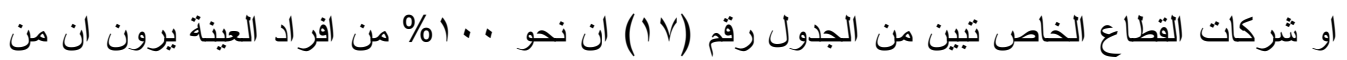

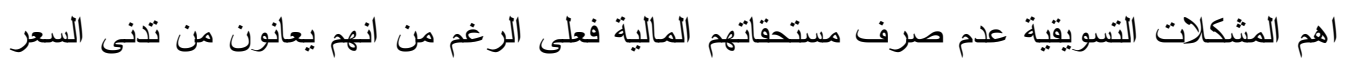

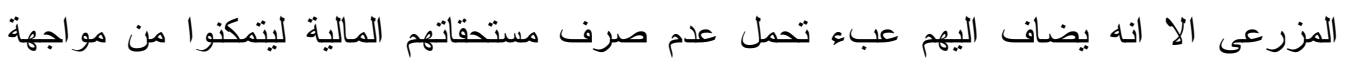
اعبائهم الاقتصادية والاجتماعية والتحضير لمحصول الموسم الثالى، وذلك بالاضافة لارتفاع قيمة

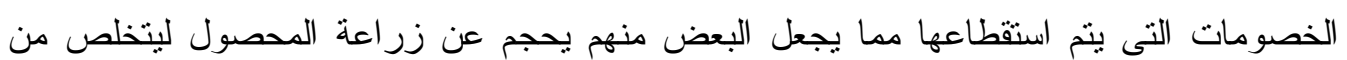
تلكك التبعية ويتمكن من بيع مايزر عه و الحصول على مستحقاته فى نفس اللحظة.

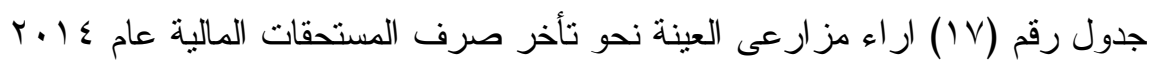

\begin{tabular}{|c|c|c|c|c|c|c|c|c|c|c|}
\hline \multicolumn{2}{|c|}{ دمنهور } & \multicolumn{2}{|c|}{ ابو المطامير } & \multicolumn{2}{|c|}{ ايتاى البارود } & \multicolumn{2}{|c|}{ الخز ان } & \multicolumn{2}{|c|}{ ابو حمص } & \multirow{2}{*}{ البيان } \\
\hline$\%$ & التكر ار & $\%$ & التكر ار & $\%$ & التكر ار & $\%$ & التكر ار & $\%$ & التكر ار & \\
\hline 1.. & $\xi$. & $1 .$. & Ir & 1.. & $1 \xi$ & $\ldots$ & r. & $1 \ldots$ & $1 \varepsilon$ & نعم \\
\hline- & - & - & - & - & - & - & - & - & - & $y$ \\
\hline
\end{tabular}

المصدر :- جمعت و حسبت من بيانات استمارة الاستبيان

آراء مزارعى العينة نحو بعد مراكز التجميع (الشون) عن القرى

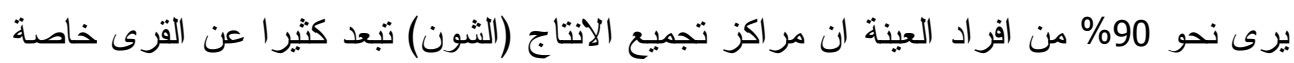

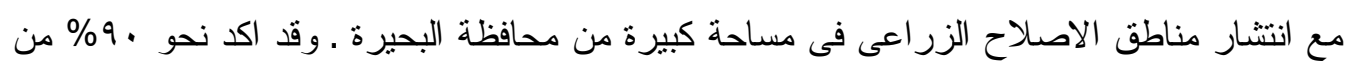

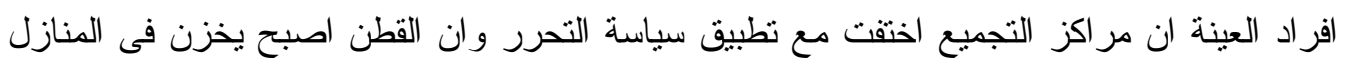

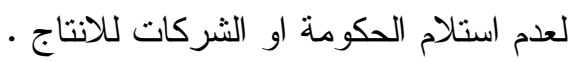




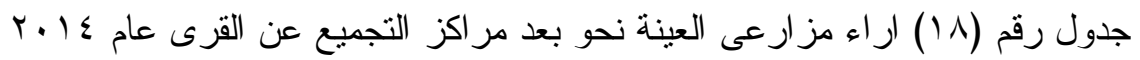

\begin{tabular}{|c|c|c|c|c|c|c|c|c|c|c|}
\hline \multicolumn{2}{|c|}{ دمنهور } & \multicolumn{2}{|c|}{ ابو المطامير } & \multicolumn{2}{|c|}{ ايتاى البارود } & \multicolumn{2}{|c|}{ الخزان } & \multicolumn{2}{|c|}{ ابو حمص } & \multirow{2}{*}{ البيان } \\
\hline$\%$ & التكر ار & $\%$ & التكر ار & $\%$ & التكر ار & $\%$ & التكر ار & $\%$ & التكر ار & \\
\hline$\wedge v, 0$ & ro & $1 .$. & ir & $\wedge 7$ & ir & 9. & IA & 94.9 & IT & نعم \\
\hline Ir,o & 0 & - & - & $1 \varepsilon$ & $r$ & 1. & $r$ & v.l & 1 & $y$ \\
\hline
\end{tabular}

المصدر :- جمعت و حسبت من بيانات استمارة الاستنيان

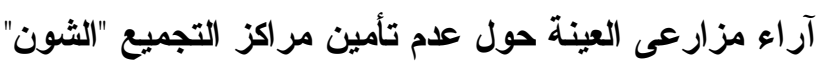

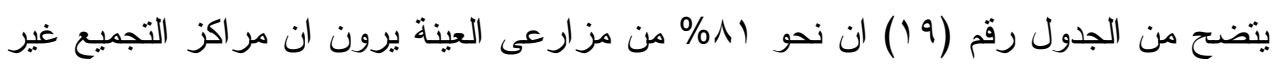
مؤمنة جيدا فهى عرضة للحر ائق و الاخطار الطبيعية كالامطار و الرياح او السرقات مما يشكل عائقا عن اتمام العملية التسويقية للمحصول ويجعل البعض منهم يحجم عن توريد المحصول .

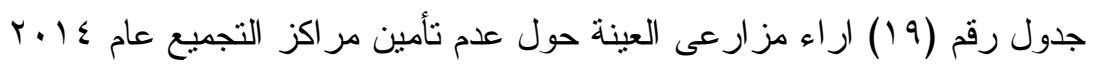

\begin{tabular}{|c|c|c|c|c|c|c|c|c|c|c|}
\hline \multicolumn{2}{|c|}{ دمنهور } & \multicolumn{2}{|c|}{ ابو المطامير } & \multicolumn{2}{|c|}{ ايتاى البارود } & \multicolumn{2}{|c|}{ الخز ان } & \multicolumn{2}{|c|}{ ابو حمص } & \multirow{2}{*}{ البيان } \\
\hline$\%$ & التكر ار & $\%$ & التكر ار & $\%$ & التكر ار & $\%$ & التكر ار & $\%$ & التكر ار & \\
\hline A. & rr & $\Delta \Lambda$ & $v$ & KI, & 1. & 1.0 & r. & $\wedge T$ & ir & نعم \\
\hline r. & $\wedge$ & \&r & 0 & $Y \Lambda, \gamma$ & $\varepsilon$ & - & - & 15 & r & $\gamma$ \\
\hline
\end{tabular}

المصدر :- جمعت و حسبت من بيانات استمارة الاستبيان

آراء مزارعى العينة حول عدم توافر الكوادر الفنية ذات الخبرة القادرة على تحديد السعر الحقيقي استنادا للرتبة ومعدلات التصافي وكذلك تعدد الوسطاء

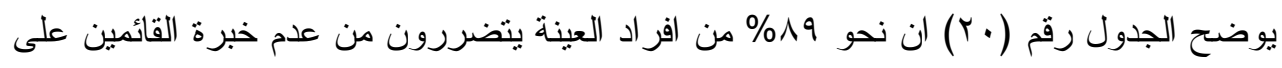

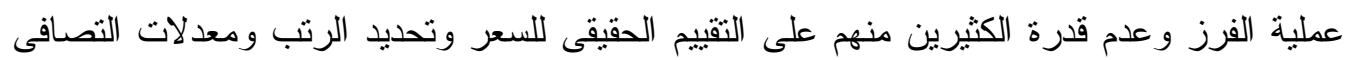

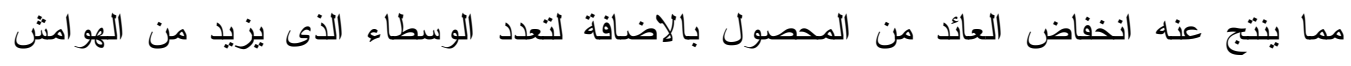

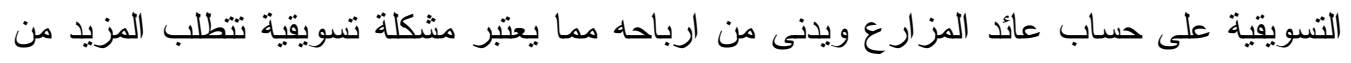
الاهتمام لانها تؤنثر فى النهاية على الصادرات القطنية المصرية وجودنها وتو اجدها عالميا.

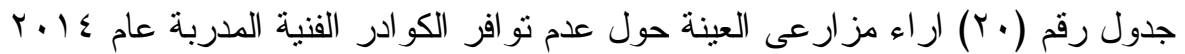

\begin{tabular}{|c|c|c|c|c|c|c|c|c|c|c|}
\hline \multicolumn{2}{|c|}{ دمنهور } & \multicolumn{2}{|c|}{ ابو المطامير } & \multicolumn{2}{|c|}{ ايتاى البارود } & \multicolumn{2}{|c|}{ الخزان } & \multicolumn{2}{|c|}{ ابو حصص } & \multirow{2}{*}{ بيان } \\
\hline$\%$ & التكرار & $\%$ & التكر ار & $\%$ & التكر ار & $\%$ & التكر ار & $\%$ & التكر ار & \\
\hline १. & m & Ar & 1. & Y৯. 7 & 11 & $1 .$. & r. & $10 . \mathrm{V}$ & Ir & نعم \\
\hline 1. & $\xi$ & iv & $r$ & YI, & $r$ & - & - & $1 \leq . r$ & r & $\gamma$ \\
\hline
\end{tabular}

المصدر :- جمعت و حسبت من بيانات استمارة الاستبيان

آراء مزارعى العينة حول عدم إدخال التعاونيات في مجال استلام القطن وقصر استلام القطن علي التئي

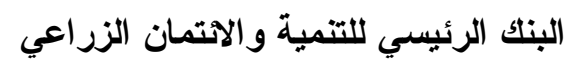

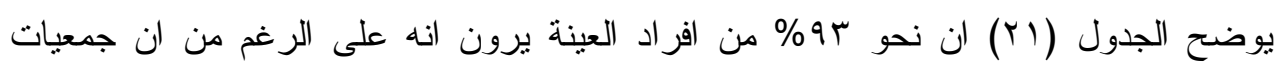

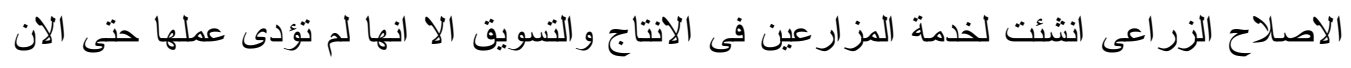
فى خدمنهم حيث ان عملية استلام القطن وتجميعه تتم من خلال البنك الرئيسى للتتمية والائتمان 
الزر اعى مما كان يحملهم اعباء مادية اضافية للوصول لمر اكز الاستلام و التجميع التابعة للبنك مما

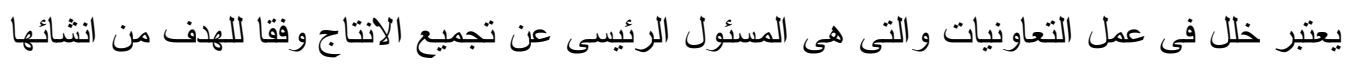

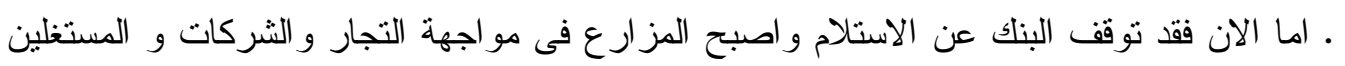
الذين يمتصون جهده وعرقه فى جيوبهر ، بالاضافة الى تجميد نشاط جمعية تسويق المحاصيل الحقلية و التى كان اساس عملها تسويق محصول القطن .

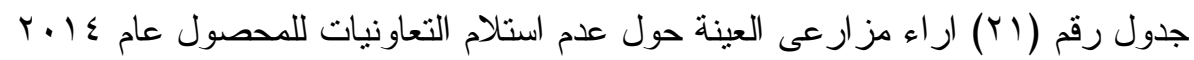

\begin{tabular}{|c|c|c|c|c|c|c|c|c|c|c|}
\hline \multicolumn{2}{|c|}{ دمنهور } & \multicolumn{2}{|c|}{ ابو المطامير } & \multicolumn{2}{|c|}{ ايتاى البارود } & \multicolumn{2}{|c|}{ الخزان } & \multicolumn{2}{|c|}{ ابو حمص } & \multirow{2}{*}{ البيان } \\
\hline$\%$ & التكر ار & $\%$ & التكر ار & $\%$ & التكر ار & $\%$ & التكر ار & $\%$ & التكر ار & \\
\hline ar,o & rr & $1 .$. & ir & ^... & ir & 9. & IA & $1 \ldots$ & Is & نعم \\
\hline V.O & $r$ & - & - & $1 \varepsilon$ & $r$ & 1. & $r$ & - & - & $y$ \\
\hline
\end{tabular}

المصدر :- جمعت و حسبت من بيانات اسنمارة الاستبيان

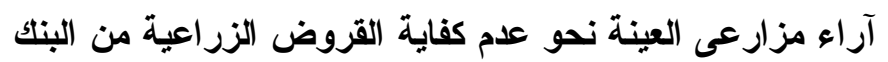

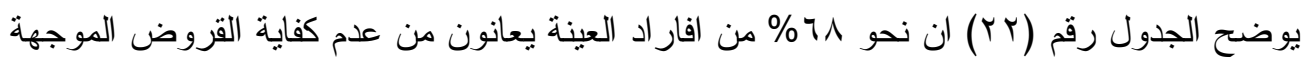
للعملية الانتاجية وعدم قيام البنك بمهامه فى دعم وتمويل الزراع في العملية التسويقية خاصة وان ونان تمويل الصادرات للمحاصيل الاستراتيجية الهامة امر ضرورى الا انهم يو اجهون الكثير من العقبات

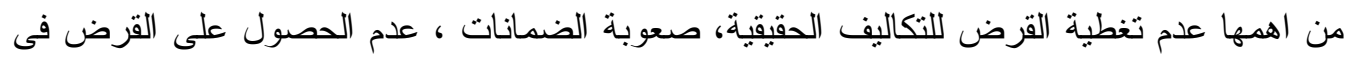

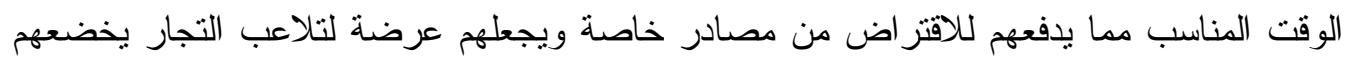
لجشع و استغلال بعض التجار الذين يبخسون ثمن المحصول ويمنصون الربح فى جيوبهم مستغلين فى ذلك عدم وجود نظام تسويقى مستقر وجيد ، وعدم الاهتمام الكافى من الدولة او الجمعيات الزر اعية

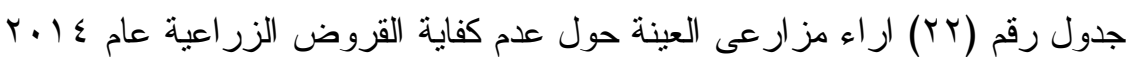

\begin{tabular}{|c|c|c|c|c|c|c|c|c|c|c|}
\hline \multicolumn{2}{|c|}{ دمنهور } & \multicolumn{2}{|c|}{ ابو المطامير } & \multicolumn{2}{|c|}{ ايتاى البارود } & \multicolumn{2}{|c|}{ الخز ان } & \multicolumn{2}{|c|}{ ابو حمص } & \multirow{2}{*}{ البيان } \\
\hline$\%$ & التكر ار & $\%$ & التكر ار & $\%$ & التكر ار & $\%$ & التكرار & $\%$ & التكر ار & \\
\hline rY,o & I & Qr & 11 & $7 \xi$ & 9 & v. & IE & $V \wedge .7$ & 11 & نعم \\
\hline rr, & 9 & $\wedge$ & 1 & rq & 0 & r. & 9 & YI. & $r$ & y \\
\hline
\end{tabular}

المصدر :- جمعت و حسبت من بيانات استمارة الاستيان

آراء مزارعى العينة نحو عدم جودة التقاوى ووجود تقاوى مخلوطة

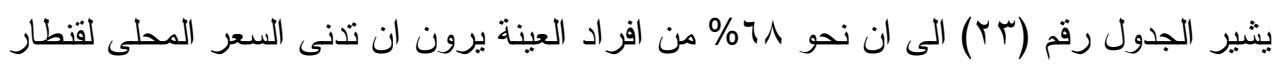
القطن يرجع الى عدم جودة التقاوى النى يحصلون عليها من المصادر الرسمية مما يؤثر على العائد

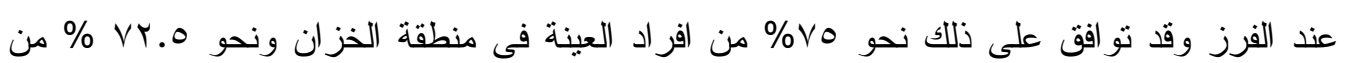




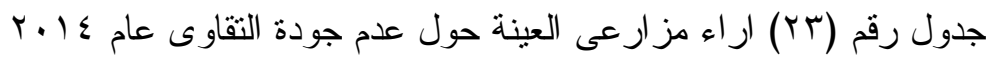

\begin{tabular}{|c|c|c|c|c|c|c|c|c|c|c|}
\hline \multicolumn{2}{|c|}{ دنهور } & \multicolumn{2}{|c|}{ ابو المطامير } & \multicolumn{2}{|c|}{ ايتاى البارود } & \multicolumn{2}{|c|}{ الخز ان } & \multicolumn{2}{|c|}{ ابو حمص } & \multirow{2}{*}{ البيان } \\
\hline$\%$ & التكر ار & $\%$ & التكر ار & $\%$ & التكر ار & $\%$ & التكر ار & $\%$ & التكر ار & \\
\hline rr,o & rq & 0. & 9 & Iళ & 9 & vo & 10 & 7 & 9 & نعم \\
\hline rr.o & 11 & 0. & 1 & M & 0 & ro & 0 & דו & 0 & $\gamma$ \\
\hline
\end{tabular}

المصدر :- جمعت و حسبت من بيانات استمارة الاسنبيان

آراء مزارعى العينة نحو انتشار عمليات الغش فى تجارة القطن

تشير المصادر الرسمية الى انتشار ظاهرة الغش فى توريد الاقطان بيعض المحافظات باستخدام

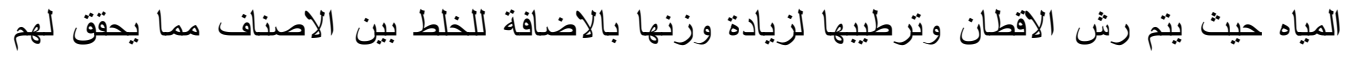

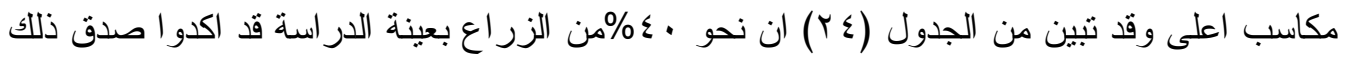

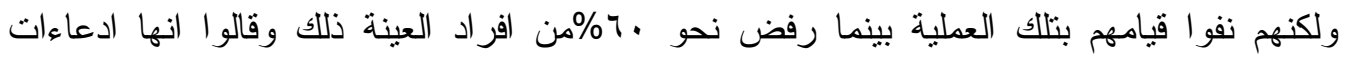
لتبرير عدم كفاءة عملية الفرز وتدنى الاسعار و انها وسيلة ضغط عليه رهم

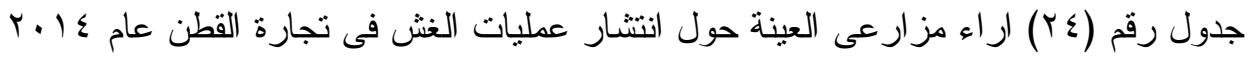

\begin{tabular}{|c|c|c|c|c|c|c|c|c|c|c|}
\hline \multicolumn{2}{|c|}{ دمنهور } & \multicolumn{2}{|c|}{ ابو المطامير } & \multicolumn{2}{|c|}{ ايتاى البارود } & \multicolumn{2}{|c|}{ الخزان } & \multicolumn{2}{|c|}{ ابو حمص } & \multirow[b]{2}{*}{ البيان } \\
\hline$\%$ & |التكر ار & $\%$ & التكر ار & $\%$ & التكر ار & $\%$ & التكر ار & $\%$ & التكر ار & \\
\hline ro & $1 \varepsilon$ & 0. & 7 & or & $\wedge$ & ro & v & דr & 。 & نعم \\
\hline 70 & rq & 0. & 9 & $\varepsilon r$ & 9 & 70 & ir & $T \leqslant$ & 9 & $y$ \\
\hline
\end{tabular}

المصدر :- جعت و حسبت من بيانات استمارة الاستبيان

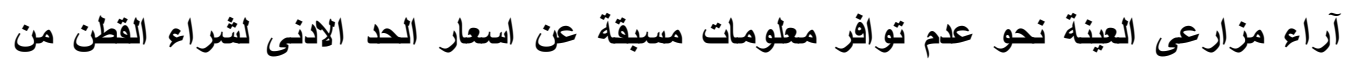
المزارعين وبالتالي احجام بعض المزارعين عن زراعة القطن والاتجاه للمحاصيل الصيفية الاخرى. يوضح الجدول رقم (Y0) ان نحو rolr\% من افراد العينة يحجمون عن زراعة القطن لعدم وضوح السياسة السعرية للمحصول و التضارب ما بين اسعار الضمان و الاسعار العالمية وعدم تحديد

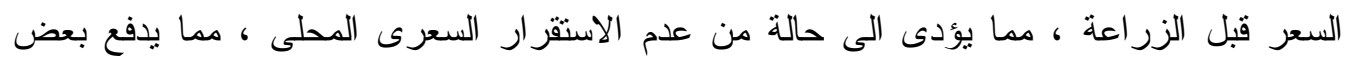

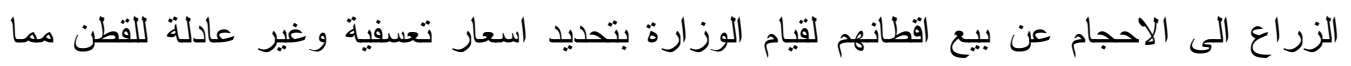

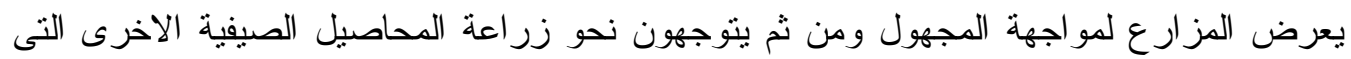
يعتقد انها ستحقق له العائد الاقتصادى المناسب لهر لهن

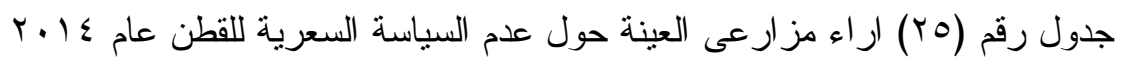

\begin{tabular}{|c|c|c|c|c|c|c|c|c|c|c|}
\hline \multicolumn{2}{|c|}{ دمنهور } & \multicolumn{2}{|c|}{ ابو المطامير } & \multicolumn{2}{|c|}{ ايتاى البارود } & \multicolumn{2}{|c|}{ الخزان } & \multicolumn{2}{|c|}{ ابو حمص } & \multirow{2}{*}{ البيان } \\
\hline$\%$ & التكر ار & $\%$ & التكر ار & $\%$ & التكر ار & $\%$ & التكر ار & $\%$ & التكر ار & \\
\hline $9 \mathrm{Q}, 0$ & rv & $\Delta T$ & 1. & $v \wedge, 7$ & 11 & vo & 10 & $T \varepsilon$ & 9 & نعم \\
\hline v.o & $r$ & iv & r & MI, & $r$ & ro & 0 & צ & 0 & $y$ \\
\hline
\end{tabular}

المصدر :- جمعت و حسبت من بيانات استمارة الاستبيان 
آراء مزارعى العينة نحو ان تزايد المخزون يؤدى لتوقف استلام المحصول من المزارعين ومن

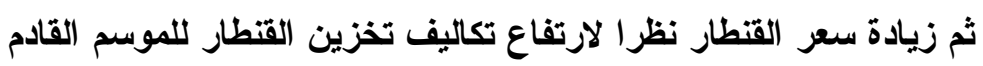

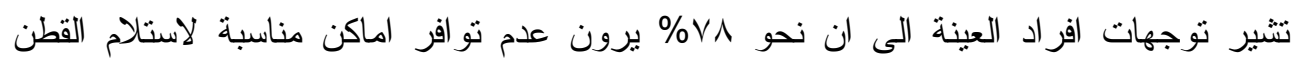
وتخزينه او تز ايد المخزون يدفع بالهيئات و الثركات المسئولة عن استلام المحصول برفض برن الاستلام

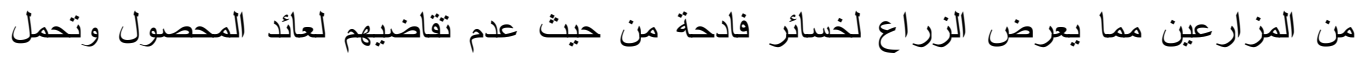
تكاليف اضافية منمنلة فى تكاليف تخزين حتى الموسم القادم مما يجعلهم فى مو اجهة خطر اكبر حيث هيث ارتفاع سعر قنطار القطن المخزون قد يهدد بعدم امكانية تداوله لارتفاع السعر عن الاسعار المتداولة فئلة فى الموسم الجديد مما يجعل المزارع فى كارثة حقيقية

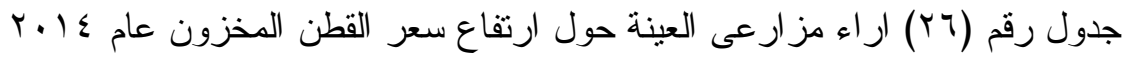

\begin{tabular}{|c|c|c|c|c|c|c|c|c|c|c|}
\hline \multicolumn{2}{|c|}{ دمنهور } & \multicolumn{2}{|c|}{ ابو المطامير } & \multicolumn{2}{|c|}{ ايتاى البارود } & \multicolumn{2}{|c|}{ الخزان } & \multicolumn{2}{|c|}{ ابو حمص } & \multirow{2}{*}{ البيان } \\
\hline$\%$ & التكر ار & $\%$ & التكر ار & $\%$ & التكر ار & $\%$ & التكر ار & $\%$ & التكر ار & \\
\hline A. & rr & $1 \ldots$ & ir & 71 & ir & 7. & ir & $v_{1}$ & 1. & نعم \\
\hline r. & $\wedge$ & - & - & is & $r$ & $\varepsilon$ & $\wedge$ & $r q$ & $\varepsilon$ & $\gamma$ \\
\hline
\end{tabular}

المصدر :- جمعت و حسبت من بيانات استمارة الاستيان

للتأكد من أن اختلاف نسبة آراء المزارعين حول كفاءة العملية التنويقية لمحصول القطن

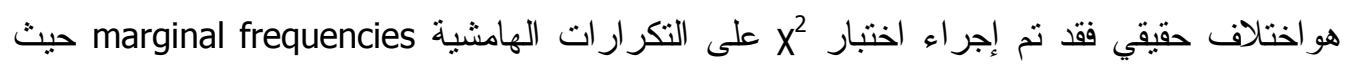
اختبار Xو هو احد الاختبار ات التى يمكن استخدامها كاختبار معلمى و غير معلمى ، فإذا أردنا اختبار

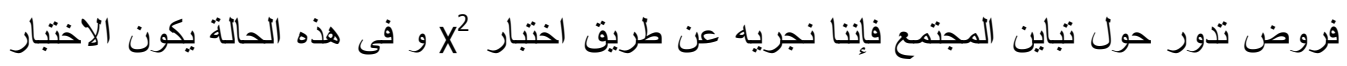

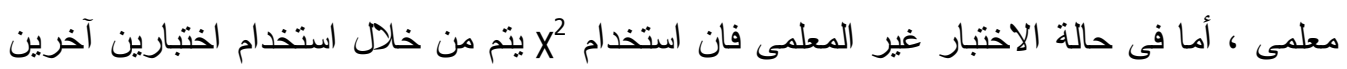

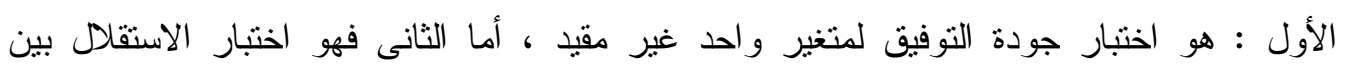

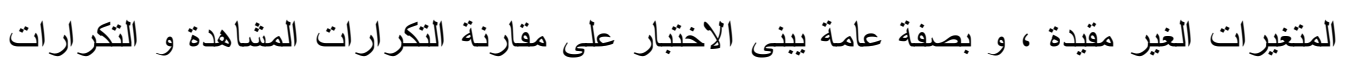

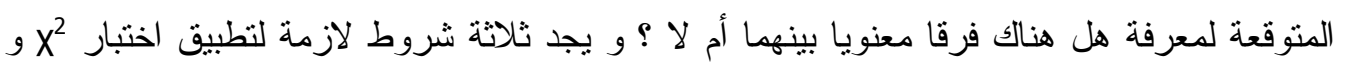

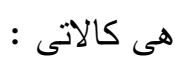

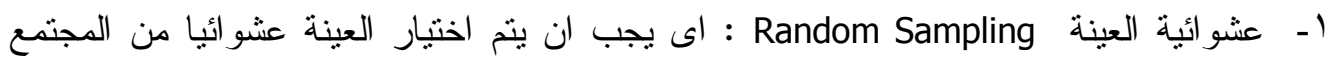

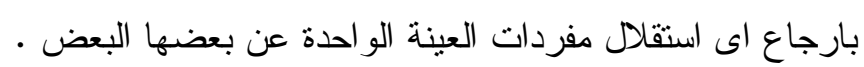

r- استقلال المشاهدات Independent of Observations : اع كل مشاهدة مشتركة فى الاختبار

$$
\text { يجب ان تكون مأخوذة من مصدر مستقل عن المشاهدة الأخرى . }
$$

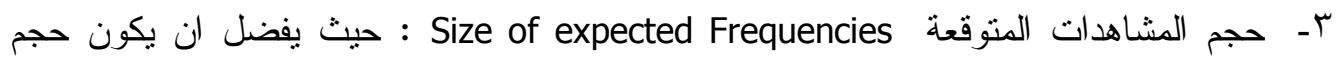

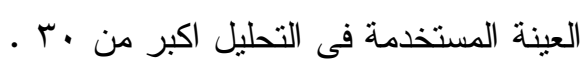

ع - حجم التكرارت المشاهدة Size of Observed Frequencies : التكرارات المشاهدة قد تكون

$$
\text { صفر او اقل من ه نكر ارات فى الخلية . }
$$


و يمكن تقديره من خلال المعادلة التالية:

$$
\chi^{2}=\sum_{1}^{k} \frac{(O-E)^{2}}{E}
$$

حيث أن:

O

E

\section{إجراء اختبار X لأراء المزارعين على مستوى العينة}

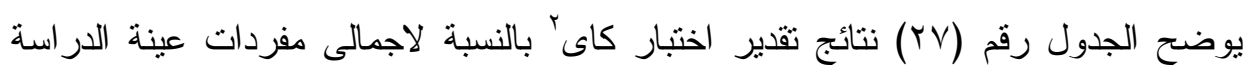

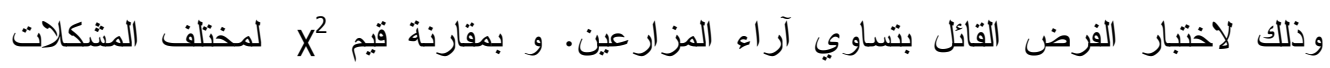

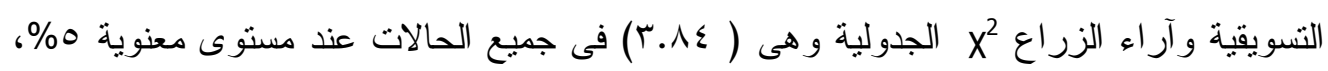

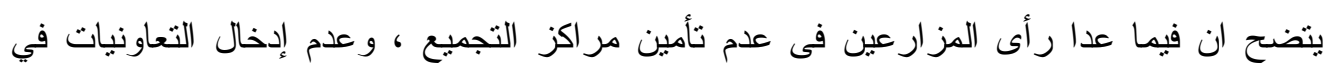

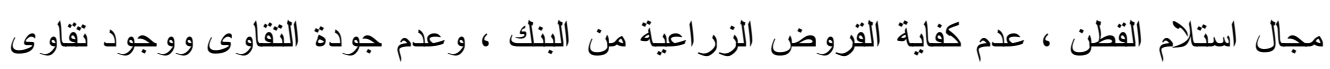

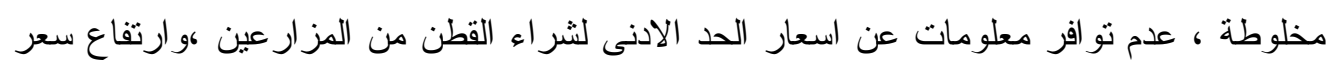

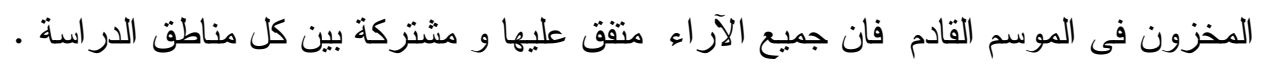

جدول رقم (YV) آر اء المز ارعين حول المشكلات النسويقية لمحصول القطن بعينة الدر اسة

\begin{tabular}{|c|c|c|c|}
\hline$x^{2}$ & $y$ & نعم & 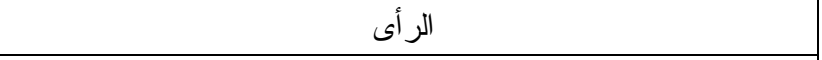 \\
\hline$\S, \mathrm{r}$ & 17 & $\wedge \varepsilon$ & لعدم تتاسب السعر المزرعى مع تكاليف الإنتاج \\
\hline r६, & . & 1.. & لأخير صرف المستحقات المالية وعدم صرف قيمة المحصول دفعة واحدة \\
\hline r.9 & $r r$ & iv & لعد مر اكز التجميع \\
\hline 1,0 & 19 & $\wedge 1$ & عدم تأمين مر اكز التجميع \\
\hline r.o & 11 & $\wedge 9$ & عدم تو افر الكو ادر الفنبة ذات الخبرة القادرة على تحديد السعر الحقيقي \\
\hline 1 & rr & ru & ي عدم إدخال التعاونيات في مجال استلام القطن \\
\hline$r$ & rr & 71 & ع عدم كفاية القروض الزر اعية من البنك \\
\hline r.o & rr & 91 & لعدم جودة التقاو وورجود تقاوى مخلوطة \\
\hline 01 & 7. & $\xi$ & انتشار عمليات الغش فى تجارة القطن \\
\hline$r$ & in & Ar & عدم تو افر معلومات مسبقة عن اسعار الحد الادنى لثر اء القطن \\
\hline 1 & YA & $V A$ & ليادة سعر القنطار نظر الارتفاع تكاليف تخزين القنطار للموسم القادم \\
\hline
\end{tabular}

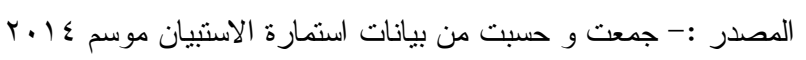

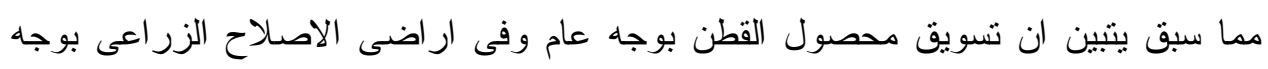

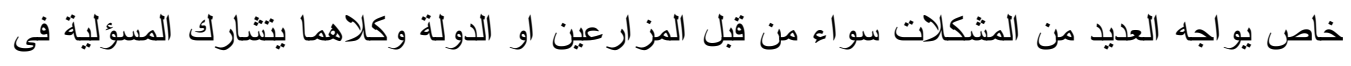

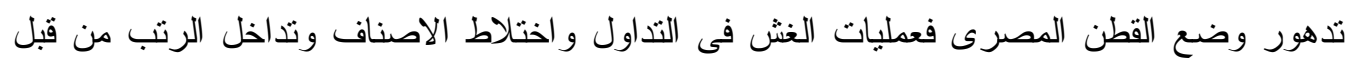

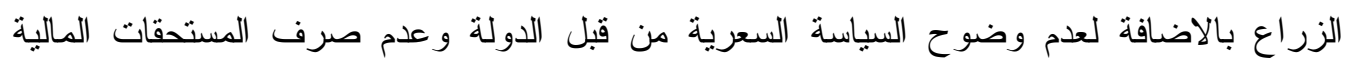

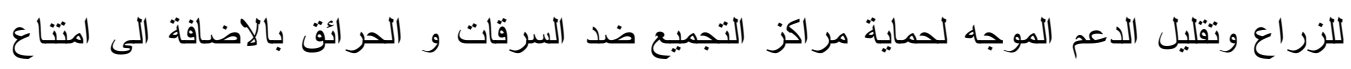
شركات تجارة وتسويق القطن عن شراء محصول القطن نتيجة إحجام البنوك عن التمويل نظرا 
لانخفاض الأسعار العالمية ، رفع الدعم الحكومي المتمثل في تحمل تكلفة التخزين و التأمين ، بما يلقي

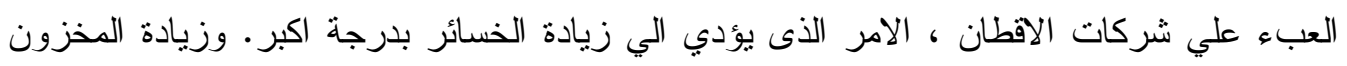

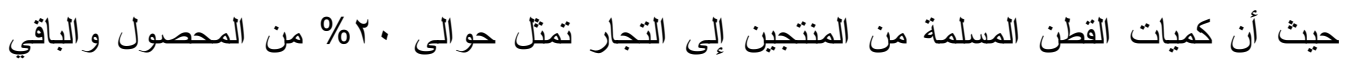

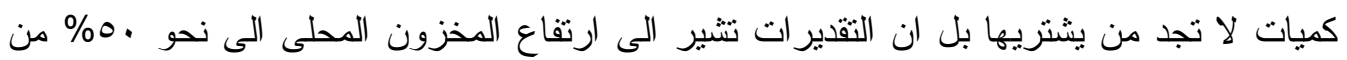

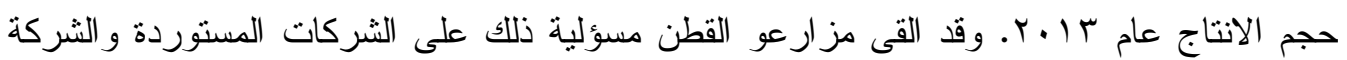

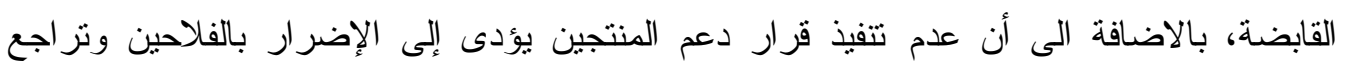

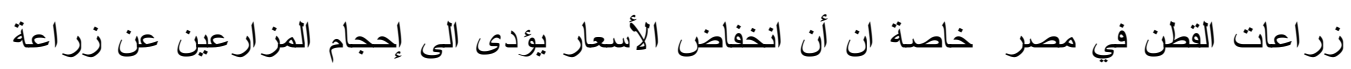
القطن و التوجه نحو المحاصيل الصيفية الاكثر ربحية والتى لا تعانى هذا الكم من المشكلات.

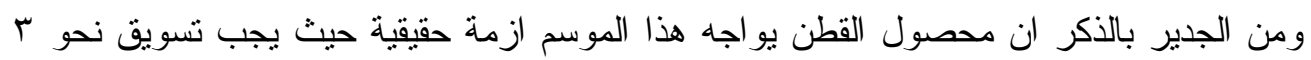
ملايين و .. ألف قنطار قطن الموسم الحالى، بعد عزوف الثركات عن الثراء، وعدم مقدرة

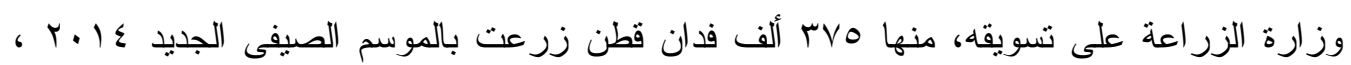

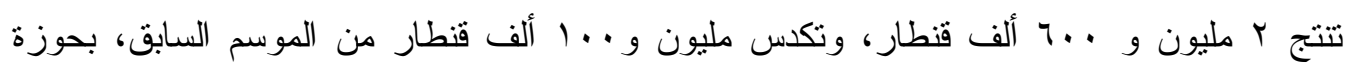

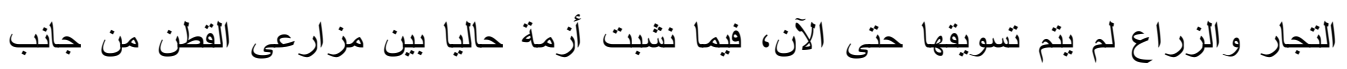

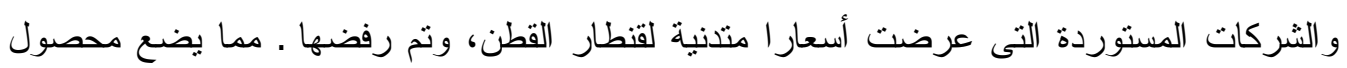

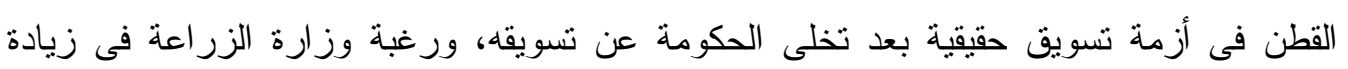
المساحة المزروعة دون حماية المزارع.

ومن ثم يجب على الدولة ممثلة فى جمعيات الاصلاح الزر اعى و الهيئات الرسمية المعنية بالقطن

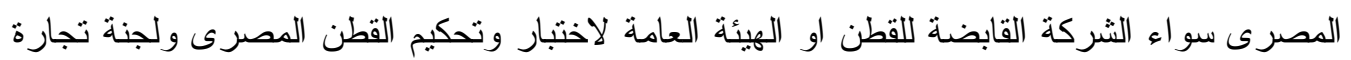

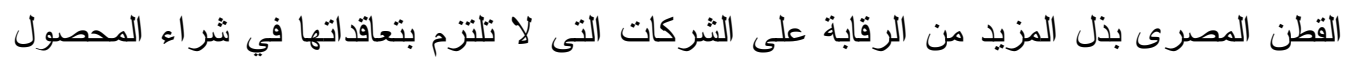
نتيجة لتدهور أسعار الأقطان عالميا حتى لو تطلب ذلك ان تتدخل الدولة ممثلة فى الجمعيات وهيئات القطن لحل المشكلة وحماية المزارعين من محاو لات الابتز از التي يلجأ إليها بعض التجان لوار التهار مستغلين

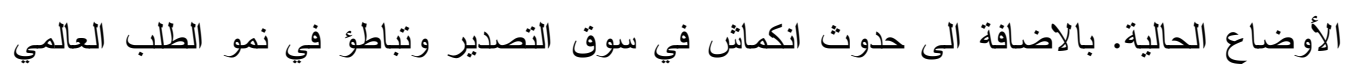

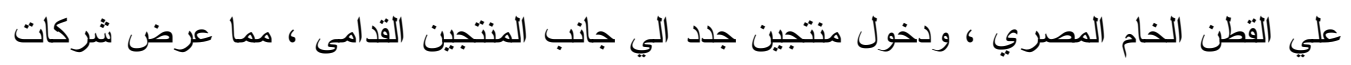

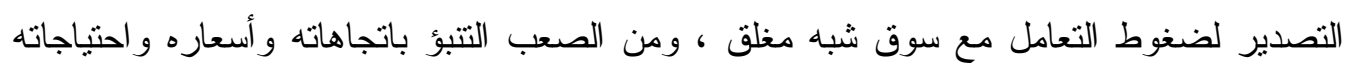

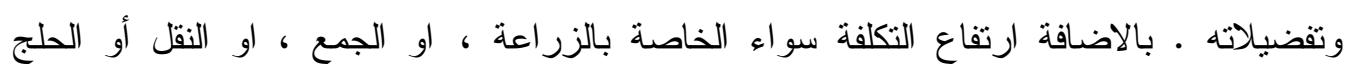

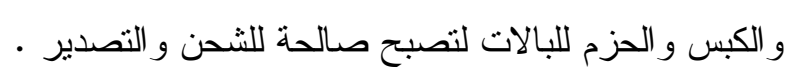

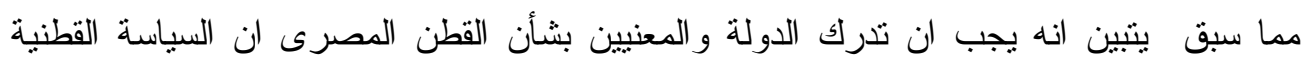
المصرية تحتاج لرؤى جديدة لانقاذ محصول تصديرى هام سواء فى صورته الخام او بعد اجراء لثاء عمليات التحويل عليه فقيام العديد من الصناعات على المحصول ومنتجاته يجب ان لندان يخلق رؤى جديدة لتطوير وتتمية المحصول وليس التراجع المذرى فى وضع المحصول بوجه عام ـ فانخفاض الطلب

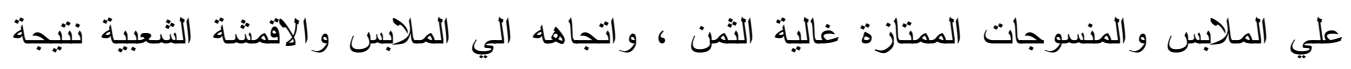

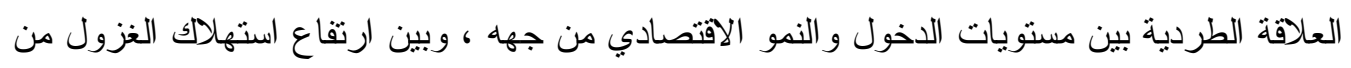
جهة اخري ، مما يؤدي الي انخفاض الطلب علي القطن الخام طويل التبلة. 
وقد حذر تقرير أعدته اللجنة العامة لتنظيم تجارة القطن (')حول الموقف الحالي لمحصول القطن

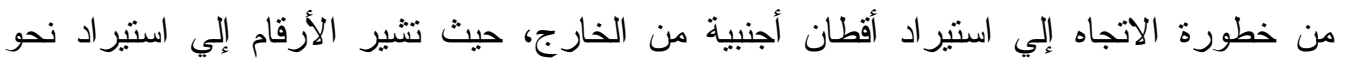

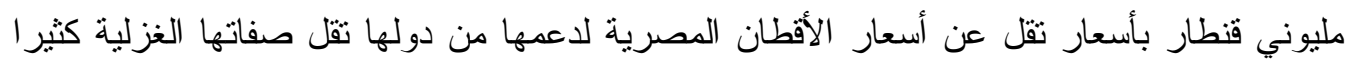
عن الصفات الغزلية للأقطان المصرية. كما يجب ان نزاجع الدولة سياستها بوجه عام تجاه القطن

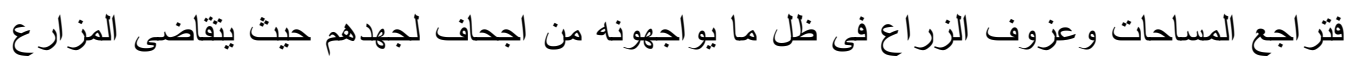
اقل من • 1\% من سعر القنطار ويذهب الفرق الى الحلقة النسويقية للمحصول سواء استمر فى دائرة الانتاج المحلى او تم توجيهه للتصدير لقد حاول البحث ان يجيب على بعض الاسئلة المرتبطة بالهو امش التسويقية وتقدير ها للوقوف على كلى

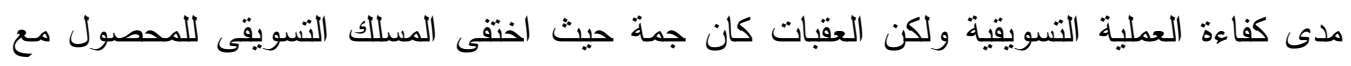

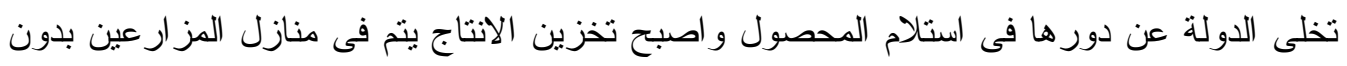

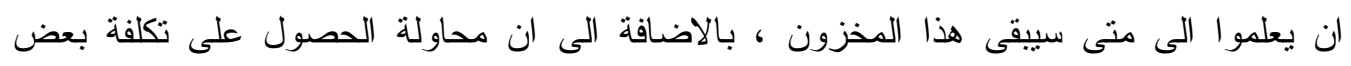

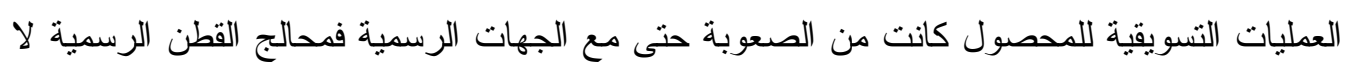

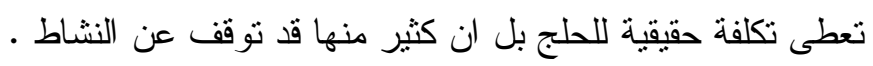
التوصيات

• العمل على تفعيل دور التعاونيات و اثثر اكها فى عمليات استلام المحصول كبديل لبنك التتمية

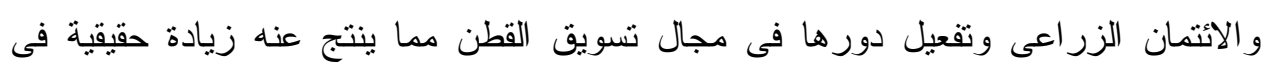

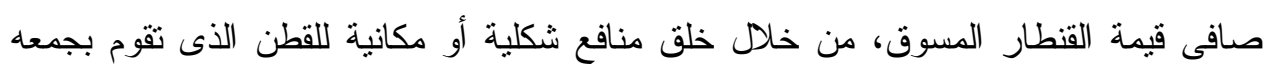

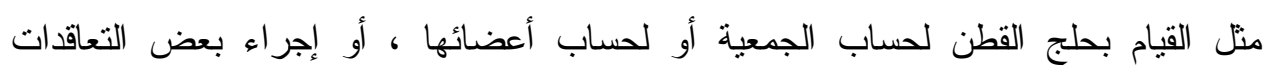
التصديرية للخارج ، أو التعاقدات مع المغازل المحلية لمدها باحتياجاتها من الغزول المختلفة . كذلك يتطلب الامر من القطاع التعاونى القيام بحملات تثقيفية وتسويق القطن على النظم المختلفة التى يجب إتابعها فى ظل نظام السوق الحر فى مجال تسويق القطن ، وكذلك الأساليب

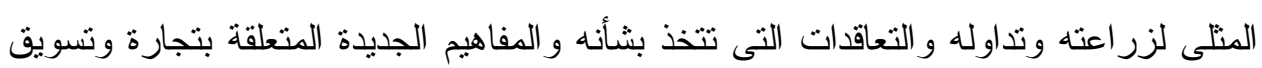

$$
\text { وتصنيع وتصدير القطن. }
$$

• وضع سياسة سعرية نتلائم مع الوضع المحلى للقطن المصرى من كافة جو انبه الانتاجية

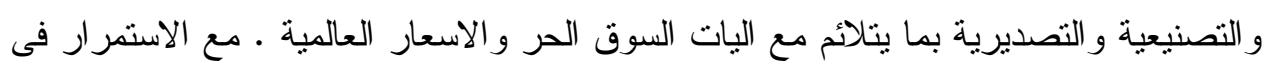

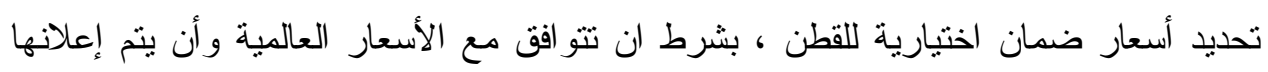

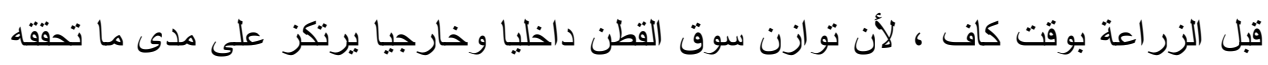

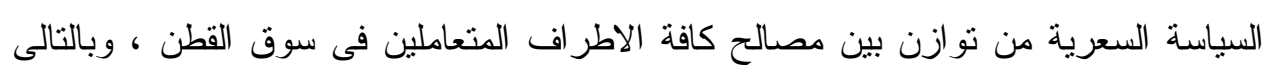
هى الاساس الذى يتوقف عليه نجاح تسويق القطن و استقر ار السوق مستقبلا.

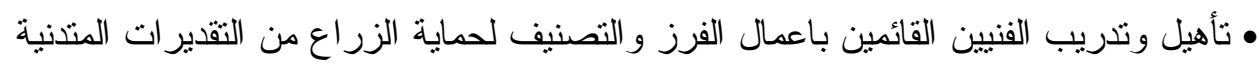


• اعداد الدراسات الاقتصادية و الفنية لتحديد الاصناف التى تتلائم مع المصانع المصرية وقدر اتها الانتاجية وطاقتها الاستيعابية ومن ثم تحديد المساحات المطلوب زر اعتها لـنع نر اكم

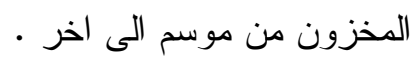

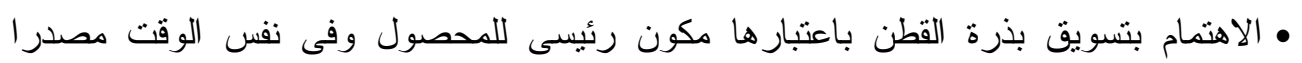
رئيسيا للزيت و الكسب. • تشديد العقوبة على الأقطان التى ينم ضبطها مخلوطة او بها غش تجارى. الملخص

يعد تسويق القطن فى مصر وما يحيط به من مشاكل وعثر ات من الاهمية بمكان وخاصــة

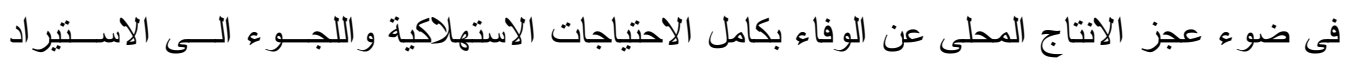

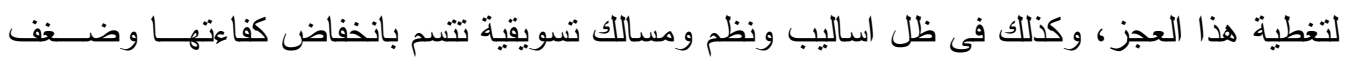

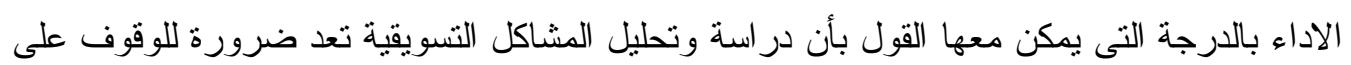

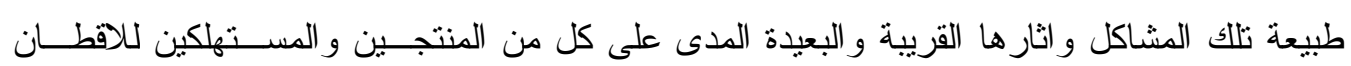

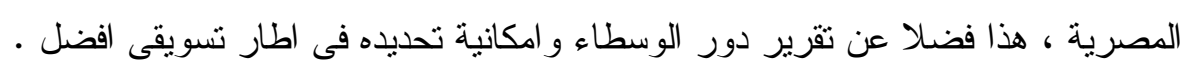

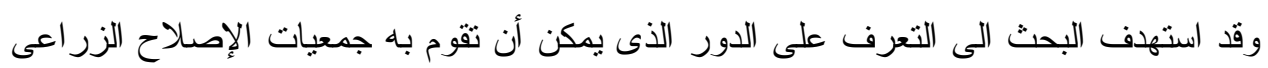

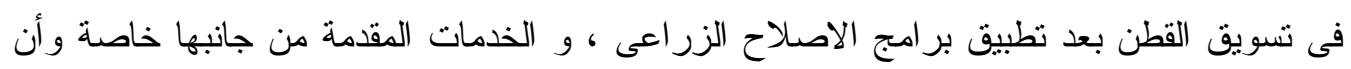

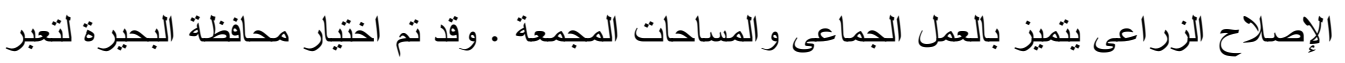

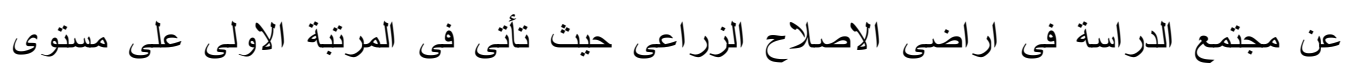

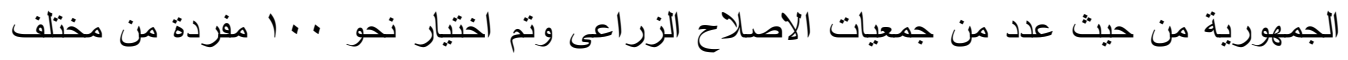

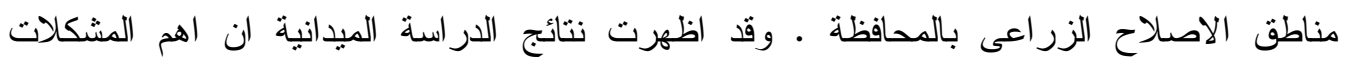

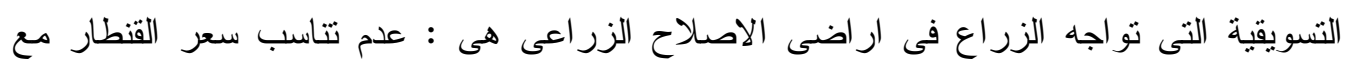
التكاليف الانتاجية المرتقعة ، بعد مراكز التجميع عن القرى ، عدم الثترالك التعاونيات فى التتلام

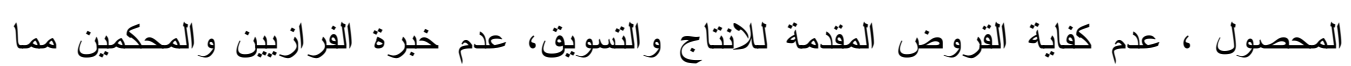
يؤدى لتدنى العائد .

\section{المراجع}

1 190V ، احمد عباده سرحان ، العينات ، مكتبة النهضة المصرية ، القاهرة

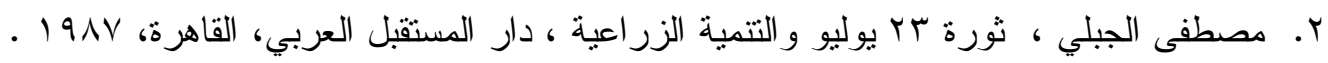

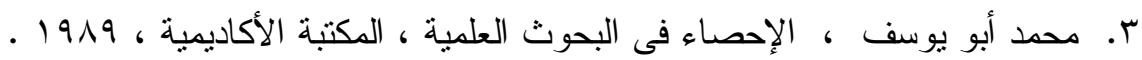

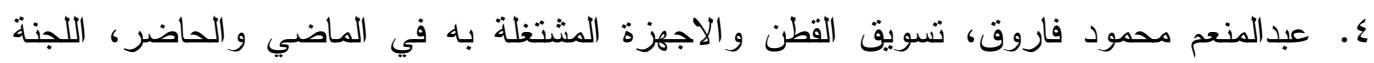

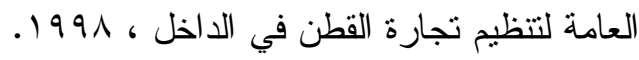

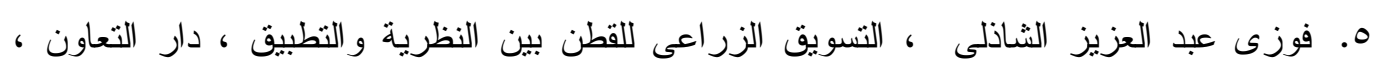

7. امنية حلمي ، تامين الاقتصاد المصري ضد تقلبات الاسعار العالمية ،المركز المصرى للار سات

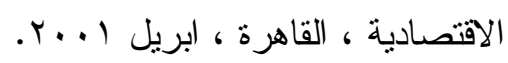


V. وزارة التموين و التجارة الداخلية ، الهيئة العامة للتحكيم واختبارات القطن ، مهام وأنشطة الهيئة ،

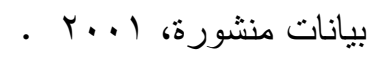
^. فوزى عبد العزيز الثاذلى و آخرون ، دراسة ميدانية حول إعادة هيكلة التعاونيات الزراعية

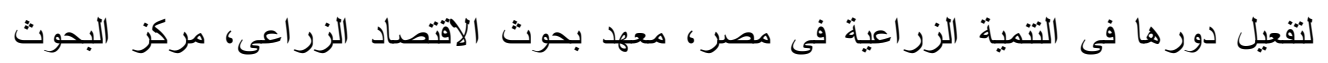

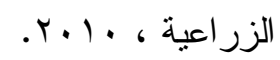

9. فوزى عبد العزيز الثاذلى ، دراسات فى التعاون - نحو تعاونيات زر اعية مطورة ، معهد

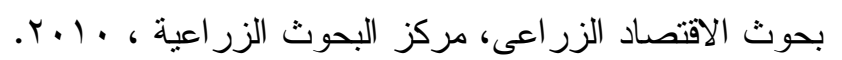

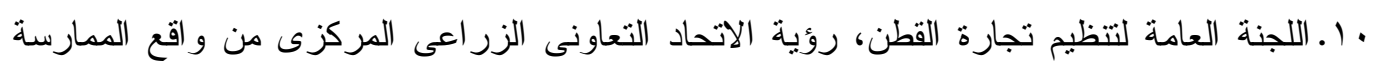

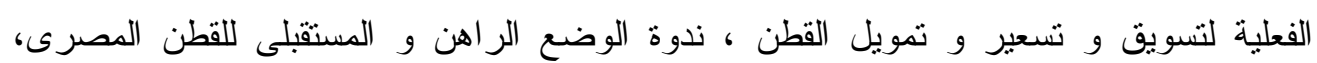
مايو r I.r.

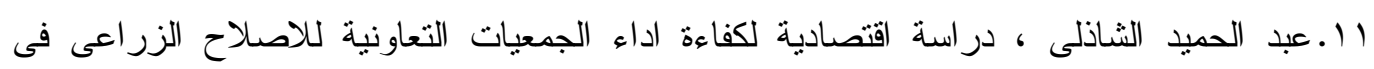

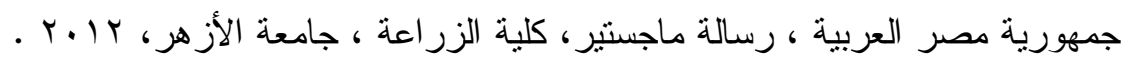

(1 ) William G.Cochran, Sampling Techniquse, Wiley EasternLimited, 1977. 


\title{
THE ROLE OF AGRARIAN REFORM COOPERATIVES IN THE COTTON MARKETING IN EL-BEHARA GOVERNORTE
}

\author{
YEHIA ABD EL-RAHMAN YEHIA
}

Agricultural Economics Research Institute, ARC, Giza, Egypt

(Manuscript received 5 Junuary 2015)

\begin{abstract}
$\mathrm{C}$ otton and its products occupy a prominent place in Egyptian economy especially in aspects like production, industrialization, consumption and foreign trade. Marketing of cotton in Egypt is surrounded with a lot of problems, especially in light of the inability of domestic production to meet the needs of the domestic textile industry of short staple cotton. Thus cotton imports are growing rapidly in order to cover this deficit. Marketing systems are characterized with low efficiency and poor performance. This study attempts to analyze the cotton marketing system in order to determine the nature of the marketing problems and their ramifications on both producers and consumers of Egyptian cotton. In addition the study spells out the roles of different intermediaries and concludes with possible recommendations that could help improve the cotton marketing system. The study focuses on the role of the Agrarian Reform Cooperatives in marketing the cotton crop of small farmers that benefit from the laws of agrarian reform laws that were issued in the 1950s and 1960s. The study relied on secondary data as well as on primary data that were collected using a structured questionnaire. El-Behara governorate was chosen to conduct the field study because it has the largest number of Agrarian Reform Cooperatives nationwide. The questionnaire covered 100 small farmers from different regions in the governorate. The results of the field study shows that the most prevalent marketing problems facing cotton farmers in the agrarian reform cooperatives are: the low price of cotton; high production costs and the long distance between the marketing collection centers and the cotton fields and consequently high transportation costs. In fact the study reveals that the Agrarian Reform Cooperatives have no role whatsoever in marketing the cotton crop.
\end{abstract}

